\section{$S F$ \\ 239 P4}

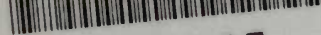
\$B 65948 ?

\title{
PROFITABLE DAIRYING
}

C. L. PECK 

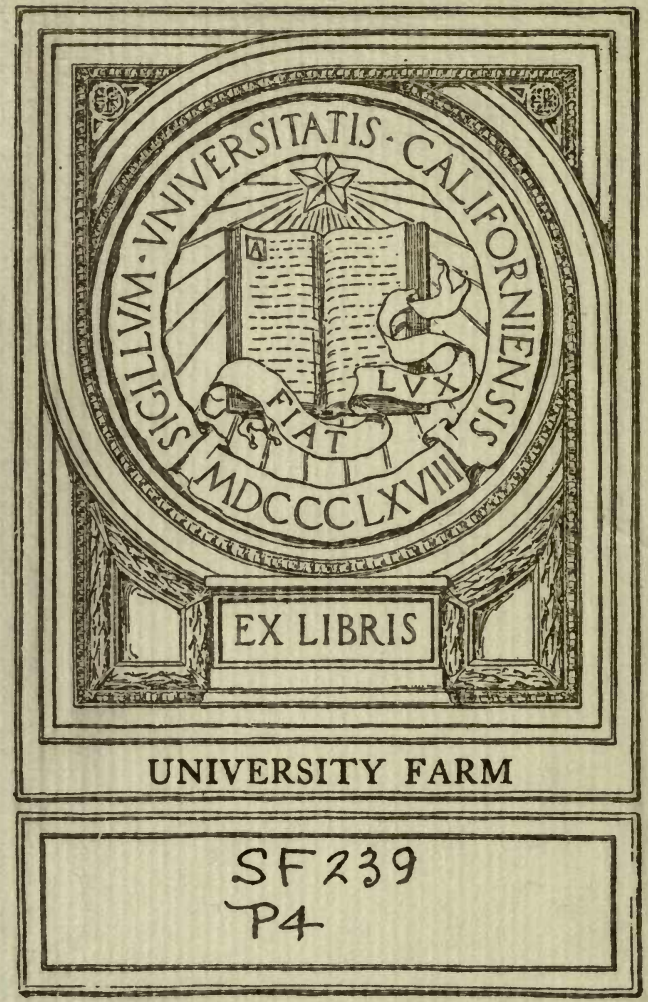



TIBTAR

UNIVERSITY

OF

CALIFORNIA 


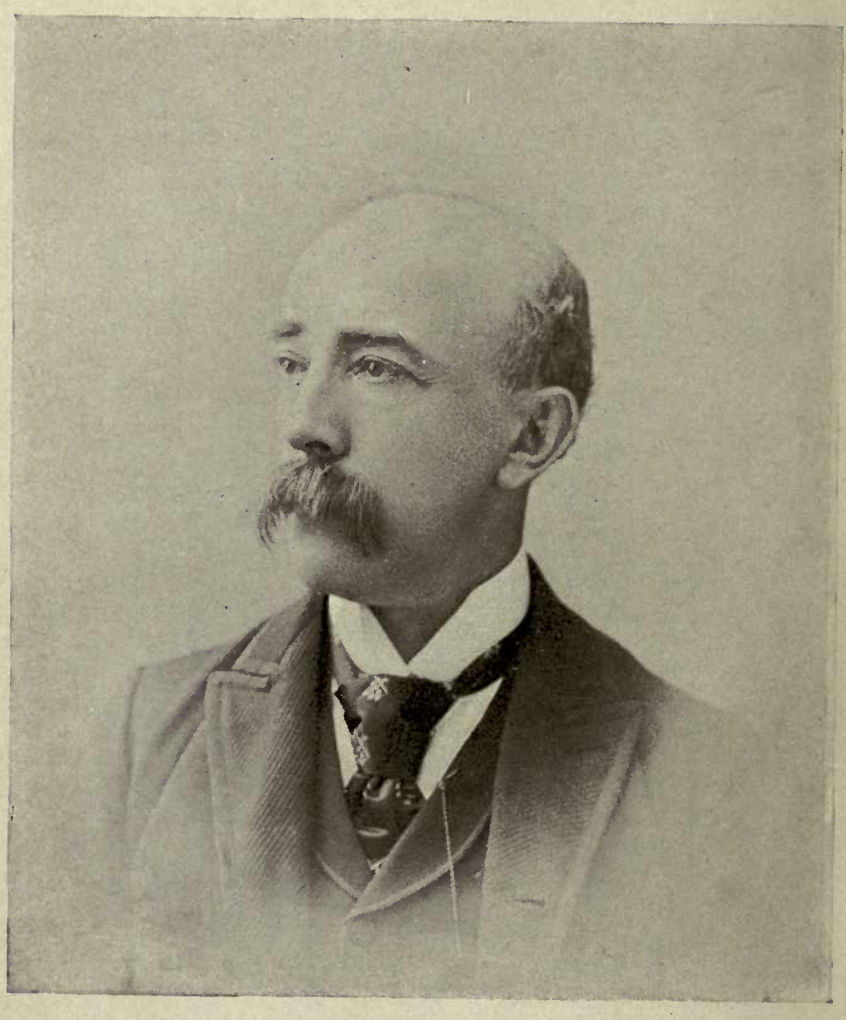

$$
\begin{aligned}
& \text { Muly Yours } \\
& \text { leLPeck }
\end{aligned}
$$




\section{PROFITABLE \\ D A I R Y I N G}

A PRACTICAL GUIDE TO SUCCESSFUL DAIRY MANAGEMENT

BY

C. L. PECK

ILLUSTRATED

UIBRARF

OF THE

UNIVERSITY

OF

CALIFORNIE

NEW YOR K

ORANGE JUDD COMPANY

1910 


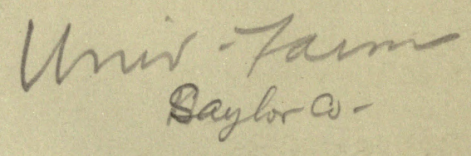

COPYRIGHT, 1906 BY ORANGE, JUDD COMPANY

Printed in U.S. A. 


\section{CONTENTS}

FAGE

Preface.

I. A Model Dairy Farm

II. Importance of the Dairy . . . . . . . 2 I

III. Physiology and Secretion of Milk . . . 23

IV. The Future of Dairying . . . . . . 27

V. Dairy Breeds . . . . . . . . . . 31

Jerseys, Guernseys, Ayrshires,

Holstein Friesians, Shorthorns.

VI. Selection of a Breed . . . . . . 56

VII. The Dairy Cow and the Dairy Sire . . . 63

VIII. Dairy Standard . . . . . . . . 69

IX. Feed of the Dairy Cow . . . . . . . 73

X. Care of the Cow . . . . . . . 80

XI. Milking . . . . . . . . . . 83

XII. When to have Cows come fresh . . . . 87

XIII. Feeds and their Value . . . . . . . 90

XIV. Care of Milk . . . . . . . . . 93

XV. Device for Ripening Cream . . . . . . 104

XVI. Churning . . . . . . . . . . . . II2

XVII. Marketing Dairy Butter . . . . . . II8

XVIII. The Dairy Barn . . . . . . . . 122

XIX. Silo and Silage . . . . . . . . . . I32

XX. Miscellaneous Topics . . . . . . . 136

XXI. Necessary Appliances . . . . . . . I43

XXII. General Hints . . . . . . . = 156

XXIII. Dairy Remedies . . . . . . . : I64 



\section{ILLUSTRATIONS}

FIG.

PAGE

The Author . . . . . . . Frontispiece

Rev. J. D. Detrich . . . . . . . . . I

3. Mr. Detrich's Barn and Stables . . . . . I 17

4. Jersey Cow, "Loretta D" . , . . , . . . 33

5. Jersey Bull, "Interested Prince" . . . . . . 36

6. Guernsey Cow, "Imp. Hayes Rosie" . . . . . $3^{8}$

7. Guernsey Bull, "Prince Rosendale" . . . . . 40

8. Ayrshire Cow, "Durwood" . . . . . . . 43

9. Ayrshire Bull, "Lucinda's Boy" . . . . . . 45

ro. Holstein Friesian Bull, "Hengerveld De Kol" • . 47

II. Holstein Friesian Cow, "Jollie Johanna" . . . 49

12. Typical Shorthorn Cow . . . . . . . . 5 I

13. Typical Shorthorn Bull . . . . . . . . 53

I4. Jersey-Guernsey Cow, "Daisey" . . . . . 65

15. Ayrshire Bull, "John Webb" . . . . . . 67

16. Cooley Elevator Creamer . . . . . . . . 94

17. De Laval Cream Separator . . . . . . . 95

18. U. S. Cream Separator . . . . . . . . . 96

19. Front View of Cream Ripener . . . . . . 106

20. Side View of Cream Ripener . . . . . . . ro8

2I. Cream Agitator . . . . . . . . . . . IIo

22. Davis Swing Churn . . . . . . . . II3

23. Skinner Butter Worker . . . . . . . . I43

24. Reversible Butter Worker . . . . . . . . I44

25. Ladle . . . . . . . . . . . . 145

26. Straight Paddle . . . . , . . . . . 145

27. Dairy Thermometer . . . . . . . . . 146

28. Floating Thermometer . . . . . . . . 146

29. Peck's Milking Stool . . . . . . . . . . 149

3o. Original Babcock Test . . . . . . . . I5:

3I. Veneer Wrapper, open . . . . . . . . 157

32. Veneer Wrapper, closed . . . . . . . 157

33. Butter Print Carrier . . . . . . . . 158

34. Eureka Butter Printer . . . . . . . . I59 



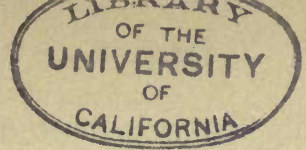

\section{PREFACE}

The last two decades have witnessed greater changes and more material improvements than any previous century. When these improvements will have so far progressed as to render further change unnecessary no man can predict. Manufacturers today are compelled to recognize these changes in their business and adjust the cost of production so as to meet the changed conditions, or they must go out of business. The farmer is now buying for forty-five dollars a better mowing machine than could be put on the market thirty-five years ago for one hundred dollars. These remarkable changes are common to nearly all industries.

The time is comparatively recent when farming was regarded as a business requiring little or no previous preparation to be successfully conducted, and was followed by a class of men who considered themselves qualified for nothing else and who selected it as a business more from necessity than from choice. In fact, in many localities this idea still prevails. The young man who thought he had a gift for mechanics, or a capacity for mastering some one of the professions, considered himself fortunate in not being obliged to live on the farm.

Competition was largely a question of local markets. The only qualification regarded as necessary was a knowledge of the business equal to that possessed by others of the same locality. All that is now 
changed. Not only is the modern, up-to-date farmer learning how to make two blades of grass grow where but one grew before, but he is also learning how to do so at half the previous cost. $\mathrm{He}$ has learned that he is called upon to meet a competition of which his father knew nothing. Steam and electricity, the telegraph and the telephone, have brought the ends of the earth into such juxtaposition that the producer of to-day is brought into competition with producers in the same line from every part of the earth. The day when farming could be followed on indifferent methods with success has passed away. Farming has become a profession. It requires as high a degree of scientific and business knowledge to conduct it successfully as any of the various kinds of business in which men engage for a livelihood, and from which they extract all the success, happiness, and pleasure that comes to them in this world.

State agricultural colleges, State and National experiment stations have opened up avenues of special preparation for the profession of agriculture not available to our fathers. They offer to the farmer boy an opportunity to fit himself, tuition free, for his life work equal to that opened to any other class. Josh Billings' advice to his son "Seek to know something of everything and everything of something " is no longer applicable. In his time the curricula of our colleges sought to cover a general knowledge of many things. We live now in an age of specialties. The college curriculum shows this. To complete the special courses taught in any of our great universities would require continuous study for more than one hundred and fifty years. Safer advice nowadays than 
Josh Billings' would be: "Seek to know all that particular branch of the something in which you are engaged." To possess as great and general a knowledge as is practicable to obtain is desirable. A complete knowledge of the business one is to follow is to the highest degree important. But it is not possible to obtain all this from any one source; no instructor knows it all.

The writer does not for one moment imagine that he will be able in this volume to condense all that is worth knowing on the broad subject of dairying. New ideas and improved methods are being developed every day. Each writer should be able to add to the work of his predecessors some new and valuable information. Nothing is more natural than the desire to know the sources of information of those who attempt to appear in the character of instructors, whether as writers or speakers. The following will serve in some degree to gratify this desire, so far as the writer of this book is concerned.

My father was one of the pioneer farmers of northern Pennsylvania. I was born and reared on the farm. My earliest recollections are connected with the clearing of the land, the logging up and burning of fallows. At the death of my father the farm upon which I was born fell into my hands, and I was compelled to make a study of the subject of agriculture. About I895 I became a lecturer on agriculture in Pennsylvania, and from that time until the winter of 1902-3 spent much of the institute season among the farmers of the State. From my associates and the farmers with whom I was brought in contact in this work, as well as from my own per- 
sonal experience, I acquired information which I endeavored to put into practical use in the dairy on my farm, which is run as a dairy and stock farm, stocked with the best Ayrshire and Jersey cattle and their crosses that I could find or breed.

In this little volume I have sought to emphasize rule and system as productive of accurate and correct results, and to give such practical hints on dairying as will enable the reader to improve his methods, better his condition, and more nearly attain that point in his business known as success. If I have succeeded in presenting new ideas or methods that will in any way tend to lighten the burden of the farmer, advance the profession of farming, or elevate social standing or aspirations, this work will have accomplished the purposes for which it was designed.

C. L. PECK.

Coudersport, Pa., 1906. 


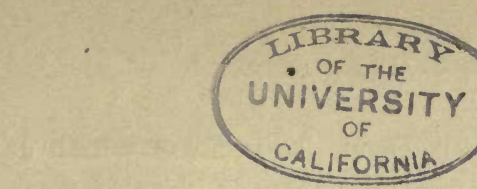

\section{PROFITABLE DAIRYING}

\section{CHAPTER I}

\section{A MODEL DAIRY FARM}

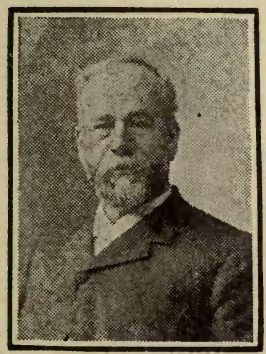

J. D. DETRICH

The American Agriculturist of New York, published the first complete account of the remarkable dairy farm of the Rev. J. D. Detrich, in Montgomery County, $\mathrm{Pa}$., in the vicinity of Philadelphia. In a recent letter, Prof. W. G. Johnson told the author that his attention was first called to this farm by a friend while he was attending a meeting of the Philadelphia Milk Shippers' Union in August, 1902. He then arranged with Mr. Detrich to visit the farm that fall, and wrote up the story which appeared in the American Agriculturist, December 6 and 13, 1902. Never, perhaps, has the description of any farm caused a more profound sensation in the agricultural world than did this series of articles. This dominie was doing on fifteen acres with a dairy herd what most farmers could not accomplish on one hundred.

The story was copied from the American Agricul- 
turist in many languages, and government experts and men from all over the country flocked to see the place and the remarkable man who had accomplished such marvelous results. As the issues of the American Agriculturist containing this series of articles have long since been out of print, the entire description of this now world-famed dairy is reprinted herewith by special request. In passing, however, it should be said that Dr. Detrich is now general manager and superintendent of "Harvest Home Farm," the property of C. S. Kates, of Chester County, Pa. $\mathrm{He}$ is improving this old and sadly neglected place of three hundred and forty acres, of which eighty-six acres are in timber, and is putting into practice the same lines of intensive culture, on a large scale, that were followed on his diminutive place near Philadelphia.

The following account of this model dairy farm is reproduced herewith by courtesy of the American Agriculturist:

\section{GENERAL APPEARANCE OF THE FARM}

One of the most interesting dairy farms in America is located in Montgomery County, Pa., near Philadelphia, and is owned and managed by the Rev. J. D. Detrich. This farm is all the more remarkable in that it represents perhaps one of the best illustrations of intensive culture and management in this country. On fifteen acres a herd of twenty-seven dairy cattle, in addition to two horses, are now maintained. All the roughage, litter, bedding, etc., necessary for these animals is grown on this place. There has been no attempt to make a big display in buildings and other 
equipment, but the ordinary farm buildings, such as are seen on the average farm in this country, are in use.

The simplicity of the buildings and equipment, together with the general surroundings, make this one of unusual interest to the farmer of small means. Here has been developed one of the most intensive systems of culture and rotation in farm crops for the feeding of dairy animals that can be found at any place. The feeding and management of the herd has been systematized and regulated to a degree of proficiency that can not be excelled at any experimental station. The work on this place is carried on by one man and a small boy, with the exception of the harvest season, when other help is secured for gathering the crops. One man handles the herd and attends to the feeding, as well as looking after other small details about the farm. The herd at present consists of sixteen cows in full flow of milk, two young bulls, and nine head of young cattle, in addition to two horses. They are all comfortably housed in an ordinary stable.

One notable thing is the quietness, docile, and contented air of the cattle in their stalls. After walking around the barn twice, the writer heard no noise from within that would indicate the presence of even a single animal. The arrangement and interior of the barn have been adjusted to meet the conditions, in the most inexpensive way, for producing milk and handling the herd in accordance with the highest and most perfect system of sanitation. Entering the stable, one is impressed with the wholesomeness of the atmosphere, particularly where so many animals 
are kept together in such small quarters. The stab. was free from all objectionable odors, and the appeas ance of the animals was conclusive evidence that the were not only enjoying their comfortable quarter but their bright eyes, loose skin, and sleek appeal ance, were suggestive of their most healthful cond tion. The snowy white walls and ceilings, and scr pulously clean cement floors between the aisles an at the rear of the stalls, gave the whole place an a of neatness rarely seen in the best-equipped stable where much is expended for that purpose. In th instance, all has been accomplished at little cost i money outlay. What has been done here can $b$ repeated on other farms at very little cash outlay.

\section{A WALK OVER THE FARM}

The walk over the farm, in company with $M$ Detrich, was quite as pleasing as the stay in the dair barn. As the American Agriculturist representativ passed the various plots on the small farm, a piece clover, seeded August 20, about three months sinc was carefully examined. It was as thick on th ground as the hair on a dog's back, and matted und one's feet like the nap on a velvet carpet. The de tails about the cultural methods of seeding and cu ting were interesting. Three crops a year are take from this field, said Mr. Detrich. The soil of th adjoining plot, from which the silage corn was take last fall, was as loose and pliable as though it ha just been gone over and torn in pieces with a stron tooth harrow. There was an entire absence of weed and, from appearances, the land was in perfect cor dition for the reception of another crop without fur 
ther working, yet it had not been touched with an implement of any kind since the crop of corn had been laid by. The adjoining two and one-half acre meadow, from which thirteen big two-horse loads of hay were taken, was as complete a mass of vegetable growth as was seen in the clover field. This was thickly covered with freshly made manure, hauled from the stables daily.

"This field," said Mr. Detrich, "will be plowed in the spring and put in corn, a part of which will be used later for filling my two silos of sixty tons each."

The representative of the American Agriculturist asked Mr. Detrich how long he had owned this property, and when he began dairy operations on an intensive and extensive scale, to which he replied as follows:

"I came in possession of this place about twenty years ago, at which time I knew little or nothing about dairying, or general farm operations. In fact, I had only a vague idea of the value and practical utility of cattle, and knew less about crops. My knowledge of feeding was very limited, and the value of dairy products and individual animals had never been considered by me in any especial way. In 1882 this farm maintained one horse and two cows, the latter being thoroughbred Jerseys, both of which were registered. One died, and the other cow was retained and bred from year to year, forming the basis of my present herd. My first business experience in dairying was the sale of a fine bull calf for $\$ 50$. The mother of this bull was a remarkable cow, and one of her heifers, when twenty-two months old, made nine and one-half pounds of butter in one week, besides fur- 
nishing milk and cream for a family of five. I found ready market for this butter at 42 cents a pound, and could have sold much more if I could have furnished it. This cow, registered No. 2028 in the American Jersey Herdbook, bred seven heifer calves in succession. From two of these cows and three heifers with their first calves, I sold sixty-five quarts of new milk, had cream to use for a family of five, besides making and selling ${ }^{1} 565$ pounds of butter during the year. Thus encouraged, I began a more careful study of dairying, and soon found there was opportunity for many improvements on my farm."

\section{SOILING AND SILAGE}

"Your perfect system of soiling must have been developed only after a most careful study of your surroundings, and a close application to the principles worked out by others?"

"At first the soiling problem was more puzzling to me than the management of the dairy herd. Through the splendid bulletins issued by our agricultural experiment stations and colleges, and a most careful study of 'Josiah Quincy on the Soiling of Cattle,' which was the best work I could find at that time on the subject, I laid the foundation for my farming operations. This book by Quincy has since been superseded by more recent, up-to-date works by Prof. Thomas Shaw on 'Soiling Crops and the Silo,' and 'Forage Crops Other Than Grasses.' But with Quincy as my guide, I began a perfect system of rotation and soiling, using rye, scarlet clover, red clover, timothy, oats and peas, corn and barley, in succession. 
I frequently have barley four and one-haif feet high in October, and I let it stand just as long as I can. If it looks like frost, I cut the barley, putting it in piles or cocks, where it remains for some time."

"When do you begin feeding soiling crops direct from the field, and how long do you continue feeding them?"

"This depends somewhat upon the season, but I usually begin feeding direct from the field April 23 and continue until November 26, or about seven months. Every bit of forage and material that comes from the field goes through the fodder cutter before it is given to the stock. I cut it in quarter-inch lengths and feed it. I cannot afford to pasture, and therefore my cattle are never turned on any of my land. Last year I fed from my farm thirty-one head of cattle and two horses."

"I presume you depend upon silage for a large amount of your winter feed?"

"Yes, I have two silos, side by side, at the rear of the barn. These I fill with second crop corn from a four and one-half acre field. I plant it in rows three feet apart, and drop the seed three of four grains to the foot. It is put in by hand, and covered with a corn coverer. I go over this later with a weeder, and keep the ground in perfect condition. I cultivate shallow and thoroughly, as often as I can go into the corn. It usually grows very rapidly; in one instance I had in six weeks corn that hid the horse during cultivation. All I could see was his ears as he went down the rows. I like to have corn pretty well glazed when it is put into the silo." 


\section{THE HAY CROP}

"How do you prepare and handle your hay crop?"

"I seed for hay August 20, never before. I take off the crops of oats and peas from the land, and give it a thorough coating of manure, putting in a reversible sulky plow, and breaking it up thoroughly. I harrow and reharrow many times. I do not believe that land can be in a too finely pulverized condition for seeding. I use a seeder, and go over the land both ways, so as to insure a very thick and uniform stand. I use six quarts clover, five quarts timothy, two and one-half pounds alsike, and one pound red top per acre. This I know is a pretty large amount, but in fifteen years $I$ have never missed a single crop, and have invariably had a good stand. I always count on cutting three crops from my hay fields each year.

"The first cutting is made in June, when the clover is just in bloom; the second about six weeks later, when the clover is in bloom the second time. This, however, depends somewhat upon the season. Five or six weeks later the third crop is cut. I cut my hay in the afternoon and leave it in the swath a short time only. It is then put in windrows, and shortly afterward in cocks, where it is left from two to two and one-half days. These are opened, if the weather is favorable, and the cocks are doubled. If the hay is in prime condition, I then stir it a second time, and put four cocks in one. It is left here a short time before being hauled to the barn or put into the rick.

"When it is handled the cock is upset, and the hay is taken from the bottom and aired. This opens 
up the hay again, exposing it to the air, and thus perfecting its curing. There is a great difference between dried hay and cured hay. I endeavor to keep all the qualities in the hay, and have found that it pays well to follow this system. When I was cutting my grass and clover the last time, several visitors who were present thought it would be impossible for us to get through with an ordinary mowing machine. In fact, it took three of us to cut the piece, with myself on the machine, and the boy ahead and man behind, and still we had all we could do to get through. The greatest difficulty $I$ have in harvesting a hay crop is to find a machine that will cut it."

"How do you manage oats and Canada field peas where they are planted together?"

"I get these into the ground just as early in the spring as possible. I set the plow about six inches, get the ground in the best possible condition, and put the peas in with a drill, about the last week in March or early in April. Two and one-half bushels of peas and three bushels of oats per acre, are the usual amounts. This is thick seeding, but my best results have come from this proportion. This is turned into hay just as soon as the peas begin to form in the pods. I do not mean that the peas should be large and hardened, but at the time the first little buttons are seen in the pods, when they are cut and cured the same as the regular hay crops. It makes a splendid feed, and is sweet and full of nutrition. The animals eat it readily, but all of it goes through the cutter before it reaches them."

"To what extent do you use crimson, or scarlet, clover?" 
"Some years ago I used a great deal of scarlet clover, but lately have not used so much. It is a splendid crop and grows very satisfactorily here. I never miss getting a stand. The land must be in tiptop condition before seeding, which is always done in August. I never use scarlet clover for hay."

\section{SILAGE AND THE SILO}

"When do you put in your first corn crop for silage? As I understand, you usually get a crop for your silo after you take off your rye hay?"

"For some years I have put the first crop of corn in on May 8, and do not begin to cut it for silage until it silks. The ensilage corn is always put on rye ground. The rye hay is fed mostly to heifers, dry cows, and horses. It is cut when in early blossom, and cured the same as the other hay, in curing cocks and weather cocks. For many years we have opened the silo November 27 , having fed direct from the field to that date."

"When do you put in barley, and do you make one or two sowings?"

"I get my first crop of barley in the ground August 5, unless the weather is unfavorable. The second sowing is made August IO-I2. I use two and onehalf to three bushels per acre, depending somewhat upon the season and condition of the soil."

"How long have you used a silo?"

"I felt the need of a silo from the very beginning, and as there was no building available, I converted an old chicken-house, $28 \times 7$ feet, and II feet deep, into a silo. The interior was studded, on which was placed a horizontal layer of boards covered with 
three-ply felt paper. Over this was placed a perpendicular layer of boards, and covered with tar. This silo was used in this condition for sixteen years, and we never lost any silage. After the new silo was constructed, a few years ago, the old chicken-house silo was torn down, and to my surprise only three unsound boards were found in the entire building. The sound boards were used in part in building an addition to the barn. I do not think there is anything better for the interior of a silo and the cement stone walls than a good coating of gas tar. In fact, it not only preserves the wood, but keeps the interior in splendid condition from a sanitary point of view. It does not injure the silage in the least.

"With so many animals, I should think you would be obliged to buy a great deal of litter for bedding, etc.?"

"I have never bought a pound of straw or litter of any kind. Everything that I feed and use is raised on this fifteen-acre farm, with the exception of cencentrated feeds, such as bran, linseed, gluten cottonseed-meal, etc. I still have one stack of straw, which was put up June 6 , 1901. I have been cutting and using this for bedding since April I, 1902, and still have a large quantity of it for future use. It is as bright and sweet as new-mown rye straw."

\section{HANDLING THE MANURE}

"I notice that your barnyard is clean, and that there is no rubbish or general litter around your stable or place. How do you handle the manure 
from so many animals, and what is done with it so as to keep the place in such a cleanly condition?"

"The manure from the stable is carted and spread upon the fields every day of the year with the exception of Sundays. During the growing season, a load of manure is taken to the field and spread on the ground where the soiling crops are taken off daily for feeding crops, and a load of forage is brought back to the stable in turn, but in the late fall and winter months, on the return trip from the field, the cart is empty. I believe that one great secret of my success is in the fact that I get the advantage and benefit of everything that is in the manure. As all the litter and bedding is cut in quarter-inch stuff, I have no difficulty whatever in handling the material. I preserve all liquids and solids, and give the land the benefit of them immediately after they are made. I have never bought a pound of commercial fertilizer of any kind, except as an experiment. In fact, with my system, I do not feel that I need it."

"Have you ever used lime of any kind?"

"I have never put on a pound of lime except once for an experiment, and do not think my land needs it. As you will note, it is as light and open as a freshly worked mole hill."

"Will you tell me something about your method of feeding and handling your crops after they come to the barn?"

\section{FEEDING THE STOCK}

"In the first place, all the roughage is cut in quarter-inch lengths, as already stated. I have a onehorse tread power for the purpose, and have the cut- 
ter and tread on the barn floor above the cattle. The material is cut and dropped down through a chute into the dairy barn below. The silage is taken out in bags, which is a very convenient way to handle it, and is not scattered all over the stable or littered around the silo. I am very careful about the methods of feeding, and never feed or bed cows before milking. I think this is a very bad practice to follow. It not only excites the animals, but there is more or less dirt or dust raised after such a procedure.

"I believe in a liberal use of bran, linseed, gluten, cottonseed, etc. I consider a ton of manure, produced where bran is used, liberally worth $\$ 14$, provided, of course, that the liquid manure is saved as well as the solid, both of which we retain. Where linseed is used, the manure is worth, in my opinion, \$17; gluten, $\$ 17$ to $\$ 18$, and cottonseed-meal, $\$ 22$. The amount of food for each individual cow depends on the size of the animal and lactation. I study the individuals very carefully, and note not only their eating capacity, but their productive capacity in milk as well. There is no general rule that I can give that will cover my entire herd.

"I like to dry a cow off four or five weeks before calving, and regulate her food accordingly. If she is slow to dry up, I limit her food to timothy hay and water, and alternately skip a teat in milking. This treatment usually drys the animal up in short time. As a rule, a cow in full flow of milk usually has, in my stable, about thirty pounds of ensilage per day. This is given in messes, three times a day. Usually about two and one-half pounds of concentrated 
food to each 1,000 pounds of the animal's weight is allowed. In this case the feeder must use his judgment about the productive capacity of the animal, and if he has no judgment he has no business to be a dairyman."

\section{MANAGEMENT OF THE MILK}

"I should think from this system you would get a very uniform flow of milk the year round. Where do you find a market for your product, and at what price is it sold?"

"The amount of milk produced by my herd during the winter and summer varies only slightly. In fact, my milk tests about 5.80 the year round. It is not tested by me, but by the parties who get it. This is considered very good milk, and I use every precaution to keep it in the very best possible sanitary condition. All the supply goes to a State Institution a short distance away, for which I receive six and one-half cents per quart. I insist on handling the cans and having the care of the refrigerator where my milk is kept at the home. I deliver once a day in cans. It is cooled carefully immediately after milking by stirring it to free it from the animal gases. It is then placed in a cooling tank, where it remains until the second milking. It is then delivered at the home in cans. The temperature is kept uniform in a refrigerator, kept scrupulously clean, according to my directions. When the milk is placed in the refrigerator by my man, the door is locked and the key turned over to the superintendent in charge. Thus my care of the product is ended. The authorities who have tested this milk 
have commended it highly for its purity and uniformity, winter and summer."

\section{STABLE MANAGEMENT}

"I judge from your statement that your cattle are kept in the stable practically the year around, with no outdoor exercise, as is practiced by many dairymen. Have you ever had any bad effects from this system, and what has been the extent of your veterinary bills during your dairy experience?"

"While my cows are kept in the stable practically 365 days in the year, I do not consider that they are unduly confined. They have perfect ventilation, clean, sanitary stalls, the most succulent food that can be obtained, and plenty of clean, fresh water. I consider that a cow that is giving a full flow of milk daily is expending as much energy chewing her cud as a horse working daily in the field. Under such conditions, if the animal is kept in perfect physical condition, she does not need the outdoor exercise so frequently talked about by many dairymen. In fact, where I see a cow standing in a fence corner during a raw, damp, sleety day (not an uncommon sight), I feel that the owner is robbing himself as well as torturing the poor animal. During the past six years my veterinary bill has been just $\$ 1.60$, and that was not due to any disorder in the herd, but to an accident. My cattle are all perfectly healthy, as can be attested by their bright, clear eyes and general physical condition. I scarcely know what it is to have a sick animal in my herd. If there is anything I am particular about, it is sanitation and comfort. 
My stables, as well as my animals, are disinfected regularly."

\section{WATER AND SALT}

"You have not yet told me anything about the amount of water you give your animals daily, and how they are salted?"

"A cow in perfect physical condition and full flow of milk should drink at least twenty-eight quarts of water daily. I have some animals that store away fifty-six quarts. Some years ago I used rock salt quite extensively, but found it was more or less unsatisfactory, inasmuch as I could not judge it as I would like. I now use the very finest and best table salt. I purchase it by the barrel, and each cow is given onefourth pound mixed in her mess every day. My animals are watered three times a day. A bucket is used for this purpose, so that I can see what each animal is doing and know pretty well what I can expect from her. It is a good guide to the feeder."

\section{MILKING}

"What precaution do you take in milking your animals?"

"Just before my cattle are milked, they are groomed and thoroughly cleaned. The attendant then washes his hands, puts on a gingham apron, and with a towel, carried in his belt, wipes off the teats and udder of the animal before he begins milking. This towel is slightly dampened so that no dust or other material can be stirred up with it. A clean towel is used at each milking. The milk is removed 


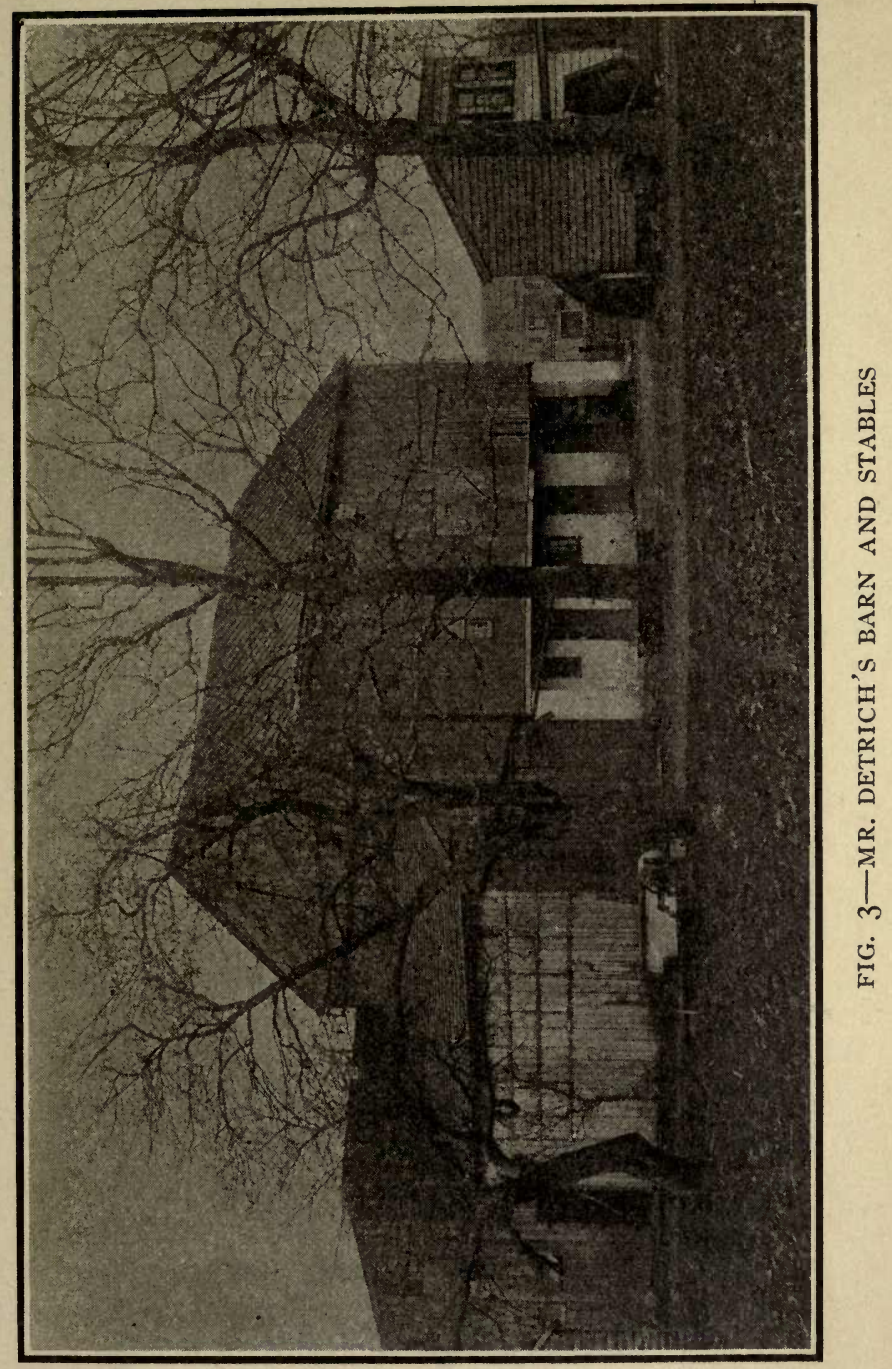


from the stable as soon as possible after it is drawn, stirred, and set away and kept cool."

\section{DISINFECTANTS}

"You stated that you believe in thorough disinfection of both animals and stables. What materials do you use for this purpose?"

"I use different disinfectants. I have had splendid results with the use of creolin, using it at the rate of one tablespoonful in one-half gallon of water. I use this in a fine spray, throwing it over the hind quarters and flanks of the animals two or three times a week. The cement troughs in which the manure and liquids are caught are disinfected with the same material after they are cleaned. At stated intervals all the stalls and floors and other parts of the building are given the same treatment. The interior as well as the ceilings are whitewashed several times during the year. With these precautions, I do not have any difficulty in keeping my herd and surroundings perfectly pure and clean up to date."

\section{NO FAILURES}

Mr. Detrich is not anxious to make a show or parade his doings on the little farm, but is ready to tell his methods when questioned. He hides nothing from your eyes, whether soil, crops, or animals. He was asked what he did on his small farm if a crop fails.

"I don't have any to miss. If I can get the seed into the ground, I am all right, wet or dry. Farmers cannot depend on summer rains. It is the winter 
supply of snow and rain the growing crops must draw from, the humus reservoir. Humus is cheap alongside subirrigation, so I try to supply humus."

"Do you think your land better than anybody else has?"

"No; a turkey will fatten in any coop if you put the food, water, and sand for his gizzard. It makes no difference whether the coop is hemlock or mahogany. I told you in the start, when I took the farm, I had one horse and two cows, and had to buy hay. The number of acres are the same to-day, but the crops have surpassed my most sanguine expectation."

"I believe you are one of the Pennsylvania State Institute lecturers?"

"Yes; my friend, the Hon. Jason Sexton, in I894, insisted on me speaking at an institute held in $\mathrm{my}$ own county, and after some persuasion I did so. I will never forget it. A quaint smile came over the audience when I began to speak, as much as to say, boys, now we will have some fun, as the parson is going to talk. But before I was done the countenances had become eager listeners. At the conclusion of the lecture I opened a two-quart glass jar of sweet ensilage, taken from my silo before daylight by my farm boy, and handed to me to show that our dairy herd had June pasture in January."

\section{FARM BUILDINGS}

Mr. Detrich's farm buildings are ordinary, as seen in Fig. 3 ; in fact, in appearance they are not up to date, as little or no paint has been used outside. 
But inside they are all comfort and convenience, as already noted. He is eminently practical, and says red gates and gold ornaments don't make cow's milk. Neither will zero weather, milk stool over the back, ice water or sheaf of corn stover. Mr. Detrich does not care much what a man thinks, but what he does and knows. "Know and do" seem to be the two words that impress you when talking with this practical and successful preacher-farmer. 


\section{IMPORTANCE OF THE DAIRY}

THERE are more than $\$ 2,000,000,000$ invested in the dairy interests in the United States, more than is engaged in the national banking business. It is estimated that it requires $18,000,000$ cows to supply the milk product of the United States. The dairy and agricultural machinery and implements used in carrying on this industry are worth over $\$ 200,000,000$. More than 700,000 persons are engaged as hired help; $30,000,000$ tons of hay and $300,000,000$ bushels of grain are consumed annually by the cattle and horses used in the dairy trade in the United States. The rapidly increasing annual production means an enormously increased importance to dairying.

Twenty-five years ago comparatively few specially bred cows-cows bred for milk or butter production -were found in the average dairy herd. Prices of such cattle were at that time prohibitive. From $\$ 300$ to several thousand dollars were required to secure a good registered animal of any recognized dairy breed. To-day a better specimen can be purchased at prices ranging from $\$ 30$ to $\$ 75$ than could be secured at any price thirty years ago. Then fourteen pounds of butter a week was about the maximum to be expected from the best Jersey or Guernsey cows. To-day twenty-five pounds a week is not unusual, and few first-class Jersey, Guernsey, or Holstein herds are to be found in which there are 
not cows capable of exceeding twenty pounds of butter in seven days without special preparation or forced feeding.

Twenty years ago 100 to 125 pounds of butter and 3,000 pounds of milk were the annual production of the average dairy cow of the country. To-day the better class of dairies average from 280 to 400 pounds of butter, and from 5,000 to 7,000 pounds of milk per cow in 365 days. Not only has the average annual production been thus increased, but the cost of keeping has been reduced by improved scientific feeding methods. This does not mean that the average amount of feed value per cow has been decreased, but that proper keeping has increased results enormously over comparative feed costs in former times.

The silo, clover, alfalfa, roots, balanced rations, and the specially bred cow, have greatly decreased the cost of producing a pound of butter and a hundred pounds of milk. In short, the dairy standard has been raised, and the up-to-date dairyman will continue to advance his standard accordingly, to cnable him to meet the competition of the future. The standard of the cow of the twentieth century must not be less than 280 pounds of butter and 5,000 pounds of milk annually, when fed proper rations under favorable conditions. No cow that fails to do this has a right to a place in the modern dairy. A knowledge of the bacteriology of fermentation necessary in the production of first-class butter, as well as those detrimental to its production, has greatly advanced dairy interests, and has enabled the dairymen to harness these forces to do his bidding. The study and control of these forces are of vital importance. 


\section{CHAPTER III}

\section{THE PHYSIOLOGY AND SECRETION OF MILK}

THIs topic is a subject upon which much has been written. Milk is one of the most common products of animals, and is inseparably connected with human existence. It is, however, one of the most mysterious products with which we have to deal. Man has been able, by breeding and environment, materially to change the quality and quantity of milk production. $\mathrm{He}$ has been able to change so far the natural condition of the cow as to cause her to give a limited quantity of very rich milk or a large quantity of milk less rich in butter fat. While the character of the fully developed individual cow may become so fixed that she is not subject to change in quality by change in feed or care, her offspring, taken at birth, may be trained in such a manner as to improve both quality and quantity by the manner in which it is reared.

Milk is a product which is subject to remarkable changes while in the body of the animal secreting it. Fright, anger, pain-all leave their traces in the milk. In the human mother the first two of these have been known to infuse the milk with poison, and to cause convulsions, and sometimes the death, of the nursing child. No doubt the same causes produce similar effects in the animal mother. Experiments have proved that when a cow has been milked on one side, she will, after being frightened or greatly excited, im- 
mediately thereafter yield milk from the other side distinctly different in quality and percentage of fat. All this we know; but how she secretes the milk and by what process it is deposited in the udder the most skilled physiologists have failed to inform us.

Writers have differed widely as to the process of milk production, each giving apparently good reasons for his position. The fact that fright or anger may, in a single minute, change the character of the milk shows that the mental state of the animal exerts a powerful control over it. The highly developed system known as milk veins, connecting the udder with the heart, shows that in some way the milk is secreted from the blood. But no writer whose works I have read has claimed to find any trace of the fluid known as milk in the blood. The fact that the milk secretion sometimes amounts to fifty quarts in a single day shows that unless the elements which enter in the milk be combined in the udder the blood would contain traces of milk. With all the investigation that has been made we must confess that we know but little about the manner in which milk is secreted.

The udder consists of two parallel glands lying longitudinally with the body of the cow and supported by strong muscles. Its interior is composed of tissue interlaced with and sustained by ligaments depending from the body. The veins, milk ducts, and glands are interwoven in a wonderful system. Within the gland tissues are the milk cells in which the fats and other elements composing milk are collected and combined. Albumen, fat, casein, water, ash, etc., are here intermingled, stored in little sacks, and, at milking, excreted as milk. The cells which 
contain the milk are broken down at each rnilking. Every observer has noticed that a cow's udder will fill one-third in the fifteen minutes prior to milking. $\mathrm{He}$ has seen a pail filled with milk from an udder which could have been placed in the pail, milk and all, at the commencement of milking. How milk is secreted is best expressed by an interrogation point.

The following substances in the indicated propor. tions enter into the composition of average milk:

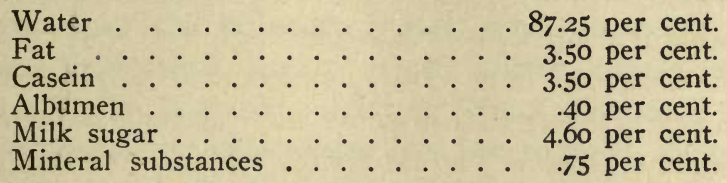

The variation of what is called pure milk from different cows in full flow is as follows:

$$
\begin{aligned}
& \text { Water . . . . . 83.65 to } 90.00 \text { per cent. } \\
& \text { Fat ........ } 1.80 \text { to } 7.00 \text { per cent. } \\
& \text { Casein ........ } 3.00 \text { to } 5.00 \text { per cent. } \\
& \text { Albumen . . . . . . . } 30 \text { to } .52 \text { per cent. } \\
& \text { Milk sugar...... } 3.00 \text { to } 5.50 \text { per cent. } \\
& \text { Mineral substances .... } .70 \text { to } .80 \text { per cent. }
\end{aligned}
$$

In the matter of butter fat it makes a great difference to the owner whether his cow belongs to the I.8 per cent. or to the 7 per cent. class. Cows well advanced in lactation often show a greater percentage of solids than the above, but the quality of milk is largely an individual characteristic, subject, however, to marked changes of ill treatment or other causes. Change of feed may control the quantity, but little control of quality can be effected by the character of the feed if fed under ordinary and normal condi- 
tions. The churning attributes of milk differ widely in different cows. Some breeds of cows produce a large butter-fat globule, others a small one. This characteristic is largely fixed by breeding, as is also the quality of the milk. In some milk the fat globules are tender and easily broken, while in other milk the globule is tough and hard to churn. Modern processes have, however, so far overcome this that less than half a pound of butter is lost in the 1,000 pounds of milk. 


\section{CHAPTER IV}

\section{THE FUTURE OF DAIRYING}

THERE has never been a time when the outlook for profitable dairying was more favorable than it is at present. The organization of the business being carried on by the United States Department of Agriculture and the different States, tends to bring the notice of foreign dealers to our butter, cheese, condensed milk, and other dairy products. Recently the Department of Agriculture has investigated methods employed in the Old World countries producing prime dairy products, notably Denmark, which furnishes England the greater part of its imported highclass butter. The methods followed there were found to be practically the same as those practiced here by first-class dairymen. But their average dairymen pay far more attention to cleanliness than do ours of the United States. The importance of cleanliness has been shown by chemists, microscopists, and experiment stations, and the knowledge published has gone far to correct prevailing evils which arise from lack of care in this respect.

Condensed milk opens a great field for the dairymen. At present the "processing" of condensed milk falls far short of perfection; "swells" and "thicks" are serious obstacles to the complete success of the business. Experience and skill are, however, lessening these difficulties. There is every reason to expect that in the near future experiment sta- 
tions will bring their scientific skill to bear upon this subject to settle and obviate these difficulties. Condensed milk will then be a commodity that can be shipped to any part of the world. When the problem of successful condensation has been solved, condensed milk will be the most prominent dairy product. The development of the condensed milk branch of the dairy industry will give dairying an impetus such as it has never previously received.

In the last few years bacteriology, as affecting the dairy industry, has received an attention that has made great improvements in the science of butter making. It is now known that the "ripening" or curing the cream results from the growth of bacteria. This knowledge has led to great improvement in the control of bacteria development, so that perfect butter can be produced with almost a certainty of results.

Most of the States have established Agricultural Colleges, where an opportunity is offered, tuition free, to young men who desire to qualify themselves in the art of butter making, in the underlying sciences and in other branches of agriculture. Every student who goes out from one of these institutions at once becomes an object-lesson for others engaged in the same business. Farmers' institutes are doing a great work in the matter of agricultural education. Information as to dairying is being rapidly and systematically disseminated. Dairy interests are being advanced accordingly, and every enterprising farmer is awakening to the fact that he must keep up with the procession if he expects to compete with others in the same business.

Breeding and feeding have taken rapid strides in 
advancement in the last ten years. Methods of preserving succulent foods for winter use have become so nearly perfected that winter-made butter possesses all the delicacy of flavor that summer-made butter does. Silage produced at a cost not exceeding \$1.25 a ton affords a cheap feed for use in winter dairying, greatly increasing the average of profit for the year. Alfalfa and other forage plants increase the amount of milk and butter. The modern cow is a highly developed machine capable of converting feeds into milk for immediate consumption or for the making of butter, cheese, and other products, at a cost much less than was possible in former times.

It is not many years ago when the herd that averaged I25 pounds of butter a year per cow was considered a good one. But the development of the dairy cow, brought about by selection and breeding, enables any enterprising farmer to possess a herd capable of averaging 300 pounds. The additional cost of feed necessary to make the difference can be made' good with the price of sixty pounds of butter. A decade ago the terms " protein," "carbohydrates," "dry matter," etc., were unknown to the average dairyman. It was common to find a man who was feeding one element in excess of what the cow needed, and letting her starve for want of enough of another, to the great loss of both butter fat and feed.

Improvements in the methods of breeding and feeding are being made such as were never dreamed of by the dairyman of thirty years ago. This improvement will continue until, in the near future, the poorly conducted dairy will be even rarer than it is now. In material advancement dairying has kept 
pace with the other great industries of the country. Cost of production has been greatly reduced by the introduction of scientific methods of feeding, special breeding, and improved processes of manufacture. The resulting product averages as good as the best of a decade ago. The advance in the price of prime butter is a special inducement for every man in the business to push to the front. 


\section{CHAPTER V}

\section{DAIRY BREEDS}

THERE are five dairy breeds that to-day admittedly stand at the front, each in its line. Other breeds are being developed that will likely become close seconds, and will perhaps push to the front rank. At present we shall speak of the five only.

\section{THE JERSEY *}

The Island of Jersey, one of the Channel Islands, located to the north of France in the English Channel, is eleven miles in length and six in width. It is the home of one of the most widely known of the dairy breeds. The climate of these Islands is warm and equable, the soil very productive. The land holdings are small. Few herds on the island number more than ten or twelve cows. Rents are high, $\$ 50$ to $\$ 100$ an acre. As a result cows are rarely allowed to roam at large, but are tethered out and at night led in, and mostly cared for by the women. Under these surroundings a delicate and highly organized race of cattle has been developed.

For some 200 years much pains has been taken to prevent the importation of outside cattle, in order to maintain the purity of the breed reared there. More

* This article is an interesting and concise presentation of the prominent points of the Jersey breed, and we do not see that any changes need be made on our part.-J. J. HeMINGWAy, Secretary of the American Jersey Cattle Club. 
than a century since a law was passed which prevented, under heavy penalty, the importation of any cow or bull. The authentic purity of this breed excels, in point of time, that of all others of English origin.

About 1840 some specimens of this breed, called "Alderneys," were brought to the United States. Authorities differ as to the identity of the Alderney with the Jersey. Whatever difference may formerly have existed, they are to-day merged under the name of Jersey. Those imported at an early date did not differ materially in form and appearance from those known to-day as the Jersey. In I860 Jerseys were first imported in considerable numbers. From that time until the nineties there were large importations, nearly 2,000 being exported annually from the island, the majority coming to the United States. At the present time most of the increase in this country comes from domestic breeding. Acclimatization has, to a degree, improved the hardihood of the breed. To-day better animals are produced from domestic breeding than have ever been imported.

The true Jersey breeder has never sought to increase the flow of milk at the cost of quality. The animals have been bred to preserve their butter-fat producing attributes, although quantity has not been entirely lost sight of. The butter-fat globule of the Jersey is large and uniform in size, or at least more nearly so than that of most other breeds. As a result it creams readily by either the gravity or centrifugal method. The average butter production of this breed, under fairly favorable conditions, will exceed 300 pounds per cow. In weight the Jersey cow varies 


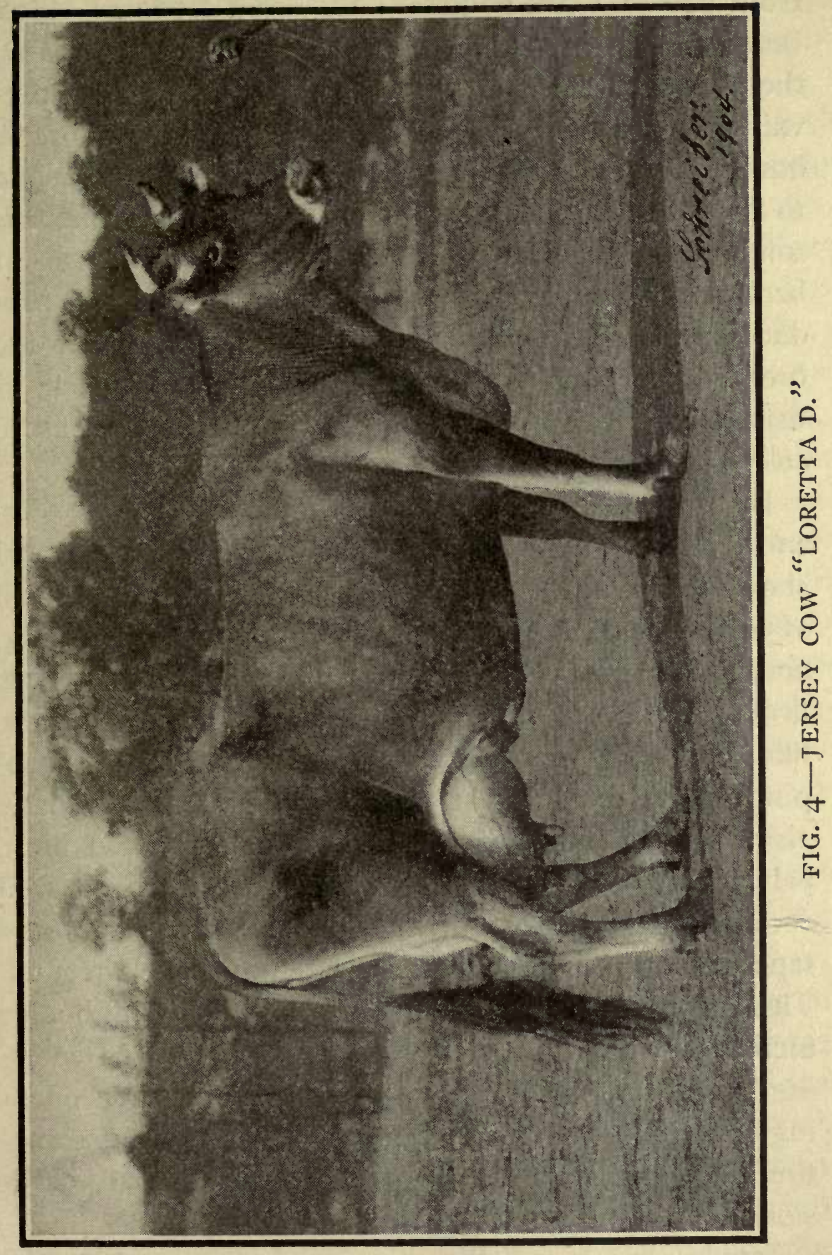


from 700 to 1,000 pounds, bulls from 1,000 to 1,800 . Breeders in this country have considerably increased the average weight of both cows and bulls. The prevailing color is fawn or light yellow. The breed, however, varies in color from broken fawn and white to dark brown. Cattle fanciers, as a rule, prefer the solid color. Experience has shown that those of broken fawn and white are as likely to be good producers as any. Some of the finest specimens of the breed have been of broken color. The muzzle is usually a strongly marked breed characteristic as to color.

In form the Jersey is, like other dairy breeds, slim and trim; has thin neck and sharp withers. Its head shows veins, and is spare of flesh; eyes large and full of expression, horns short and usually in-curving, nostrils generally large and thin. Its skin is soft, firm, silky and pliable. The legs are clean and slim, like those of a race-horse; shoulders high, back dropping below the level of the shoulders, and gradually rising to and back of the hips; hips wide and high, pelvic arch prominent. The tail, which sets on well forward, in contrast with the beef breeds, is long and tapering, with heavy brush reaching the ground. The thighs are high and incurving, flank high also incurving; milk veins large and tortuous, often entering the body through two and sometimes three openings to each vein. The udder is capacious, but sometimes inclined to be pendant, teats fair in size, occasionally cone shaped.

Jerseys are especially strong in prepotency. The grades usually show the large butter-fat globule of rich golden color. They retain this even after other 
breed characteristics disappear. For these reasons the Jersey is an excellent animal for cross and grade breeding.

The average production of the Jersey, in both quantity of milk and butter, has been increased in the last thirty years. Then the maximum production was not much over two pounds of butter daily. More than twice that amount has been produced from Jersey cows in the same time within ten years. Three hundred pounds of butter annually is not an unusual yield from an average Jersey herd under reasonably favorable conditions. A well-bred herd of Jerseys can readily be brought to over 400 pounds annual production of butter, and from 5,000 to 7,000 pounds of milk in 365 days. Individual records of 600 to 800 pounds are not unusual, and as high as 1,000 pounds and even more have been produced. They are heavy feeders and have great assimilating powers, converting food into milk and butter at a moderate cost. Without taking on flesh, they will convert more rich food into milk and butter fat than most other breeds. They do not fatten readily and are not valuable beef producers. The owner must look to milk and butter for the profit.

It would be pleasant to pass by the weaknesses of the several breeds; but the dairy student and breeder desires to be informed of the weak as well as the strong points of the breed into whose merits he is inquiring, in order to determine the feasibility of their modification. Like all other breeds, the Jersey has its weak points. Bred in the warm climate of the Channel Islands for centuries, it seems to be less hardy than some of the more northern hreeds, and 


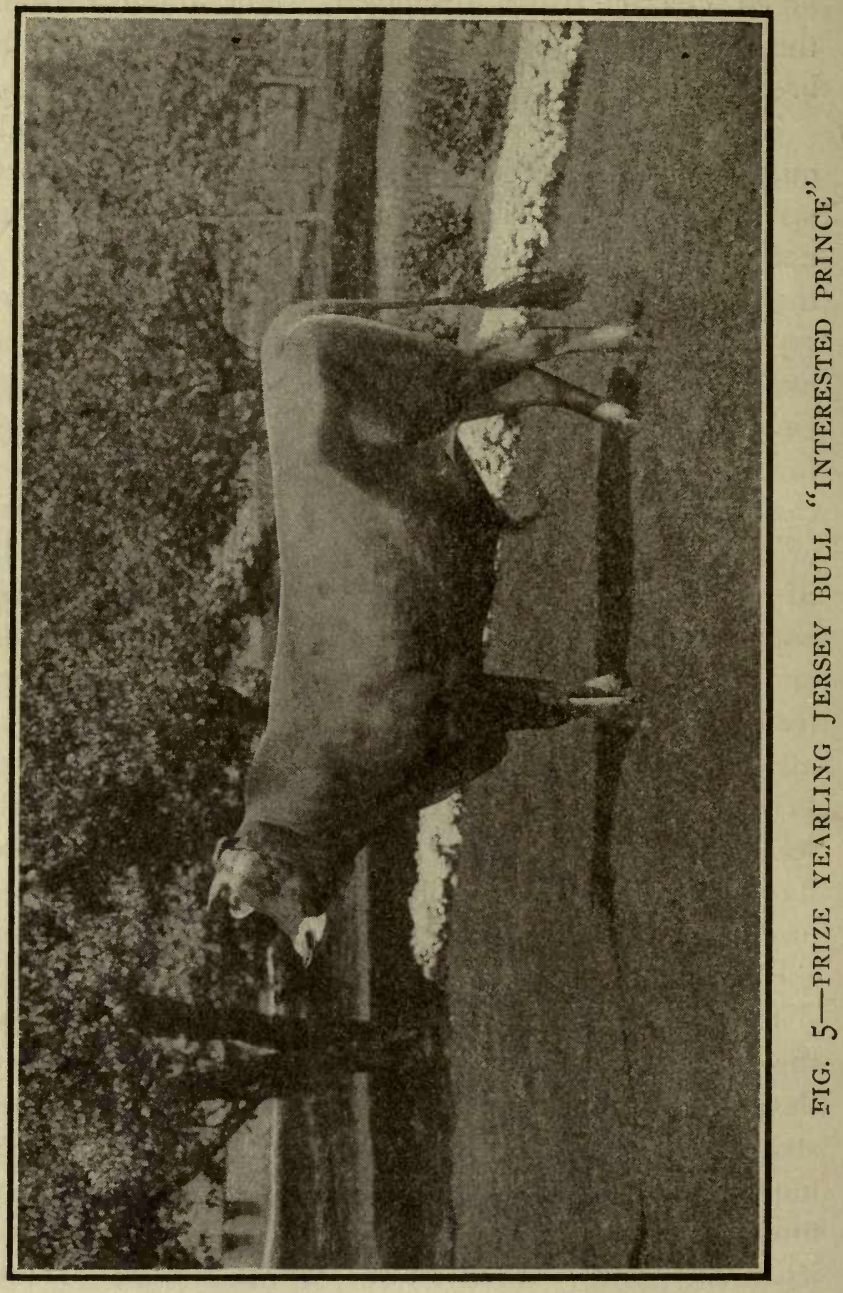


somewhat more disposed to udder weakness and difficulties. These are attributed to the hundreds of years of less perfect methods of breeding that are now applied; methods which perpetuated characteristics of no importance and even of positive detriment. But American breeding and gradual acclimatization is slowly but steadily overcoming these difficulties. In these respects the Jersey and Guernsey have much in common.

A high-bred Jersey cow and bull are shown in Figs. 4 and 5 .

\section{THE GUERNSEY *}

The home of the Guernsey cow is the Island of Guernsey, one of the Channel Islands, nine by four miles in extent. The foundation of the breed was laid by crossing the large Red Normandy on the Little Black Brittany, or the breeds which the early settlers of the island took there years ago. Since the early part of the century stringent laws have been enforced prohibiting the importation of live cattle to the island, and the islanders have given every attention to the purity of their breed.

The Guernsey is the largest and hardiest of the Channel Island breeds. An average Guernsey cow weighs 1,050 pounds and bulls 1,600 pounds. This may be due possibly to the fact that the climate of Guernsey has induced the larger growth, heavier bone, and more rugged animal. They are fawn with white markings, and present an attractive and graceful appearance. In disposition they are kind and

*Endorsed by William H. Caldwell, Secretary and Treasurer American Guernsey Cattle Club. 


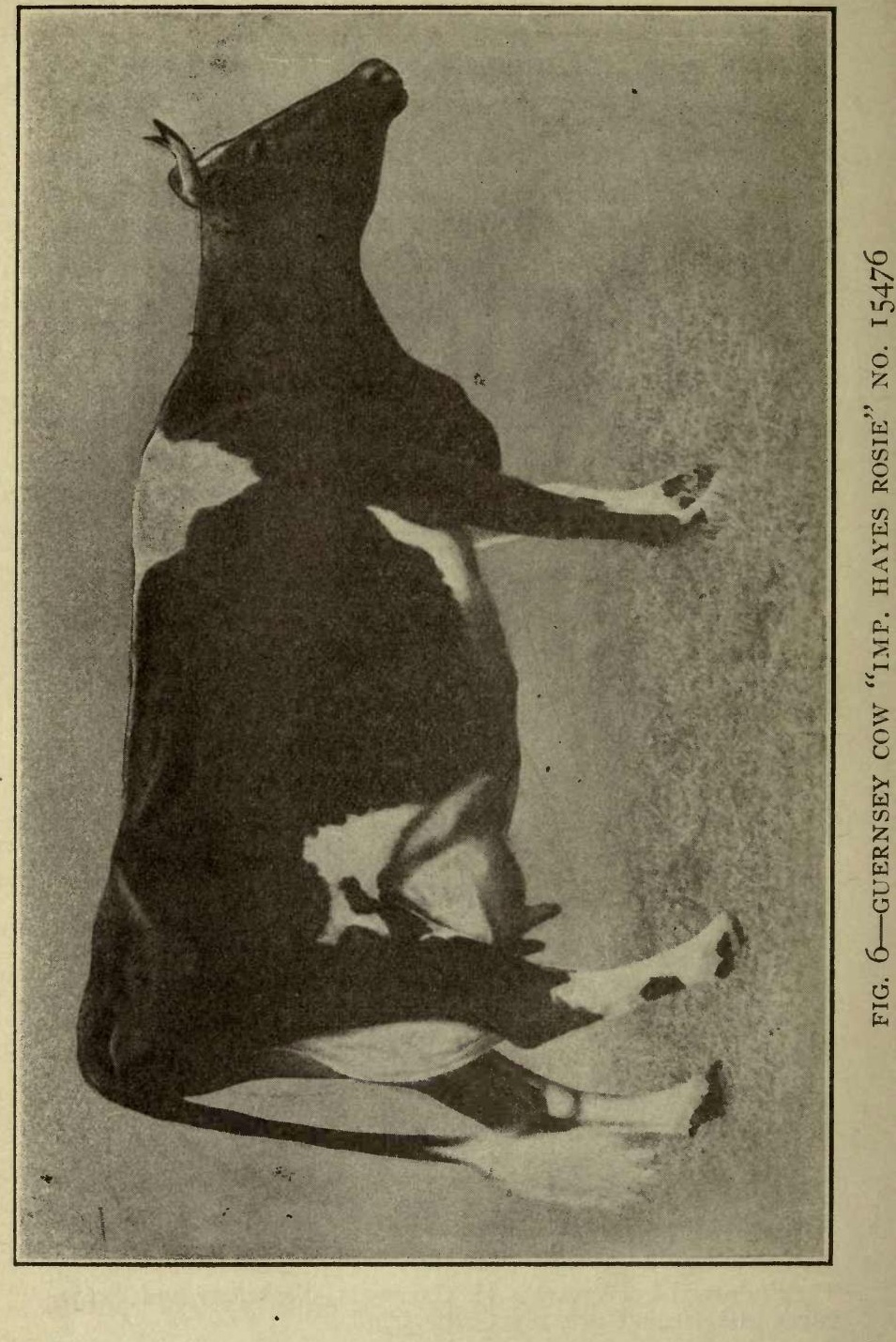


affectionate, undoubtedly due from the fact that on the island they are largely cared for by the women and children.

They have never been inbred with an idea of developing strains or families or to produce uniformity of color. They have always been regarded as the farmer's cow. A few animals were shipped to the United States about fifty years ago, but from I 870 to I 880 they began to be introduced more frequently, and from that time the importations have been in considerable numbers.

In form they are of a pronounced dairy type, so much so that the American Guernsey Cattle Club in their new scale of points have given 95 out of roo to what is recognized by the best dairy students of the country as the ideal dairy type of a cow, leaving only five points for what is usually termed as breed characteristics.

The great distinguishing feature of the Guernsey is her ability to produce cream or butter of the deepest yellow color and to do so at the least cost. This has been proven in public trials at the experiment stations, and at Chicago and Buffalo. At the latter place they showed the greatest profit in butter making over all breeds participating. Their large size, attractive appearance, high-colored milk, cream, and butter, and their quiet disposition, has won for them many friends, and they have steadily increased in favor during recent years.

They were the first breed to establish an Advanced Register on the yearly record basis, and their highest records at present time are: Princess Rhea I5479, Adv. Reg. 59, I4,009.89 pounds milk, 775.69 pounds 


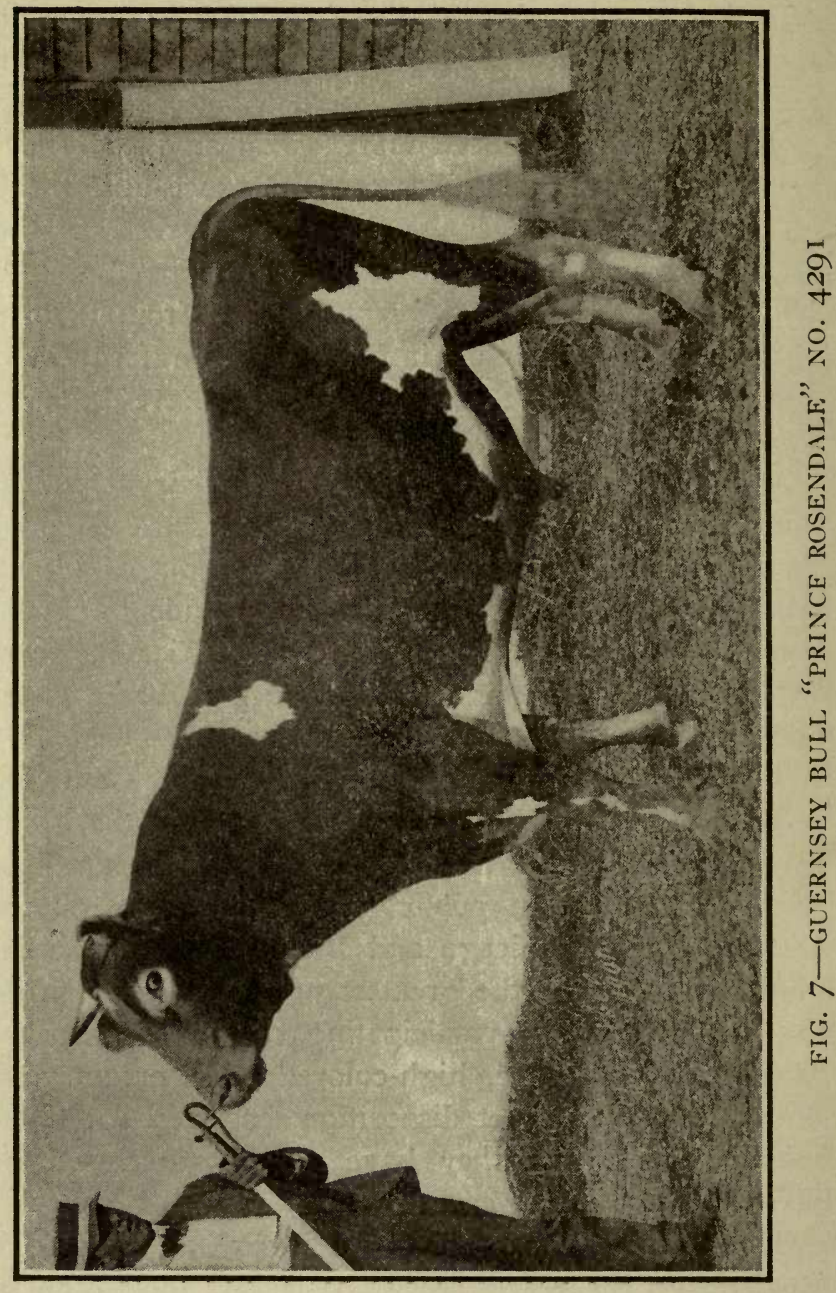


butter fat. Hayes Rosie 15476 , Adv. Reg. I16, I4,633.08 pounds milk, 714.3I pounds butter fat. Guernseys can be expected to produce from 8,000 to 10,000 pounds of milk and from 350 to 500 pounds of butter fat in an ordinarily fed and kept dairy.

One great ability of the Guernsey is to stamp her qualifications in the grading up of a dairy herd, and through the dairy sections of the East and West the Guernsey grade will be found standing high in favor and commanding $\$ 5$ to $\$ 10$ a head more in the market.

Figs. 6 and 7 show fine specimens of this breed.

\section{THE AYRSHIRE *}

The origin of the Ayrshire, like that of most other breeds, is lost in tradition. But this is of little consequence to the American dairyman; the important question with him is: "What can she do?" The County of Ayr, in the southwestern part of Scotland, is for the most part undulating and hilly. For a century, perhaps much longer, this has been the home of the Ayrshire cow. The first specimens of this breed imported into the United States arrived in 1822 , and the breed has been three-quarters of a century in building up to its present degree of perfection. The earliest importations were brought to New York State. Eight years later New England secured some animals, and in 1837 others were introduced into Canada.

* I think this a good article, candid and not overdrawn in either praise or criticism. I see no occasion to offer any suggestions.-C. M. Winslow, Secretary Ayrshire Breeders' Association. 
Ayrshires have for many years been highly esteemed both in this country and in Scotland as milk and butter producers. Their natural hardiness and muscular development, increased by breeding and by lives spent in a hilly country, have adapted them for foraging on all sorts of land; their feeding and digestive powers and hardiness have fitted them for most parts of the United States. While capable of enduring the hardships that would overcome cows of most other breeds, they respond readily to good treatment in an increase of production of both flesh and milk. Cold and storms affect Ayrshires less than most other breeds. For persistence of flow under adverse conditions they are surpassed by none.

Ayrshires, like all other well-bred milch cattle, are of a nervous temperament; under kind usage they are docile and tractable, but are quick to resent insult or abuse. Bulls when properly managed rarely become ugly. The Ayrshire cow has been bred and developed with a view to the production of an animal which will economically convert feed into milk and butter. She is a good feeder, and is an example of the Scotch adage: "The cow gives her milk by the mou." She is well adapted to the production for town market, where a liberal flow of milk reasonably rich in butter fat and solids is desirable.

Usually the color is red and white, occasionally brown. Canadian breeders have bred toward the white; Americans have preferred red. Among dairy cattle, Ayrshires are of average size. The bulls attain a weight of from 1,400 to 1,800 pounds, 1,500 to 1,600 being the desirable sizes. The larger types are prone to develop beef tendencies. The cows weigh from 


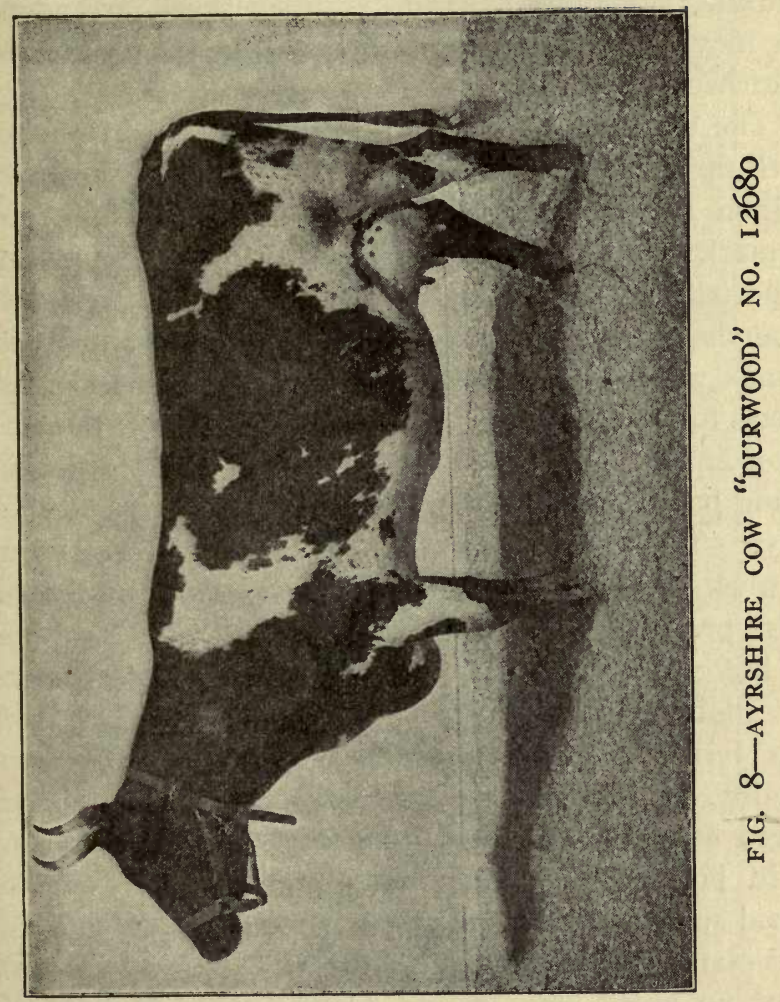


900 to $I, 100$ pounds, $I, 000$ being the average. When in milk, they carry no superfluous flesh. They are wedge-shaped, have a thin neck and head, slender muzzle, large, bright, and expressive eyes, are quick in movement, and have the appearance of extreme watchfulness.

The udder is remarkably square and blocky. It is well up in front and behind, rarely low and swinging. When not distended with milk, the udders are not remarkably prominent; but when well filled, they are especially large and well formed. A yield of 6,000 pounds of milk is an average for the breed in good hands with fair treatment and feed; for whole herds, 7,000 to 8,000 pounds is not unusual. A not uncommon annual yield for an Ayrshire is 10,000 pounds; some have reached 14,000 pounds in 365 consecutive days. Individual production of 14 pounds of butter a week is not at all unusual. Members of the breed have produced 28 pounds in seven days. The average of butter fat is not far from 4 per cent. The butterfat globule of the Ayrshire is smaller than that of the Jersey or Guernsey, and it does not cream so readily. It is also lighter in color. Members of the breed have produced 607 pounds of butter in a year.

In buying Ayrshires, care needs to be taken to avoid short teats. Most American breeders have been successful in eradicating this defect. There is perhaps no breed more nearly exempt from diseases of the udder than the Ayrshire. In breeding and milking Ayrshire cows for the last twenty years the writer has never had a case of defective teats or udders in a herd of from twenty to thirty cows.

Typical specimen Ayrshires are seen in Figs. 8 and 9. 


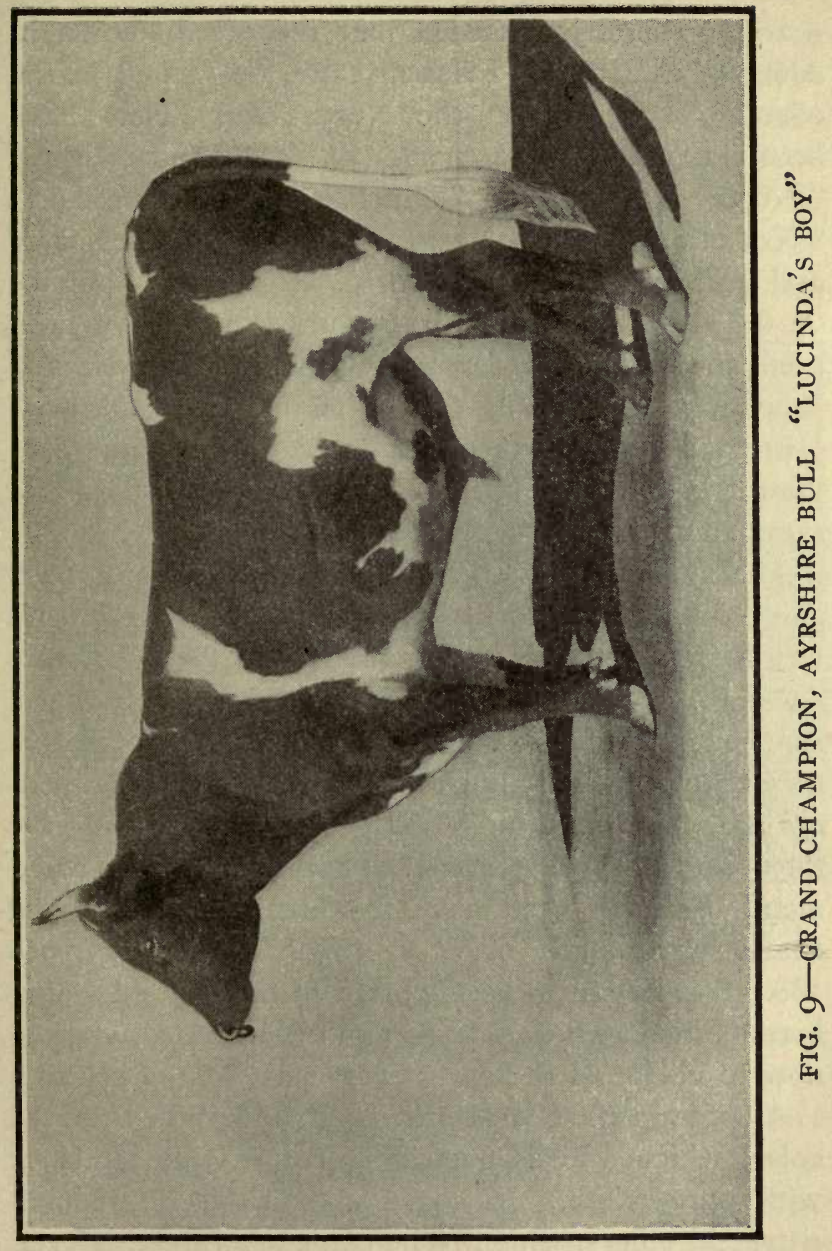




\section{THE HOLSTEIN-FRIESIAN *}

It is generally conceded that the breed known in America as Holstein-Friesian cattle originated in the country bordering on the North Sea. They have been known by the name of "Holland Cattle," “ North Hollanders," “Dutch,” "Dutch-Friesians," "Netherlands," etc. They are strongly marked black and white, and are one of the oldest and most notable of the dairy breeds. For centuries they have been bred and developed for the production of milk and supplying of food in the shape of veal and beef. History shows that they can be traced back for more than two thousand years, continuously occupying the same countries.

The animals are larger than any other recognized dairy breed, and equal the Shorthorns. The cows weigh from 1,200 to 1,600 pounds, and the bulls from I,600 to 2,000 pounds, often more. Their frame is symmetrical, large, strong, and bony. When not in milk they take on a liberal amount of flesh. The Hollanders are very proud and fond of their cattle, and give them every advantage in both breeding and environment. Few importations of this breed into the United States were made prior to 1850 . Beginning with 1880 , they began to be imported in considerable numbers. Since then they have rapidly increased, and are now to be found in nearly every part of the country.

A prominent characteristic of this breed is the color, which affords a striking contrast of jet black with pure white. In some animals black predominates; in others, white. The cattle are rarely, if ever, of solid color. Some have been nearly all white. As

\footnotetext{
* Revised by F. L. Houghton, Secretary of the HolstemFriesian Association.
} 
in the Ayrshire, the dividing outlines of the color are irregular; the black and white are never mixed; each is clearly marked and defined from the other. The neck is long, and fine and clean at juncture with the head; the head slim and spare of flesh; legs comparatively short, clean, and nearly straight; tail long, and tapering finely to full switch. The udder is often of extraordinary size, well up in front and behind.

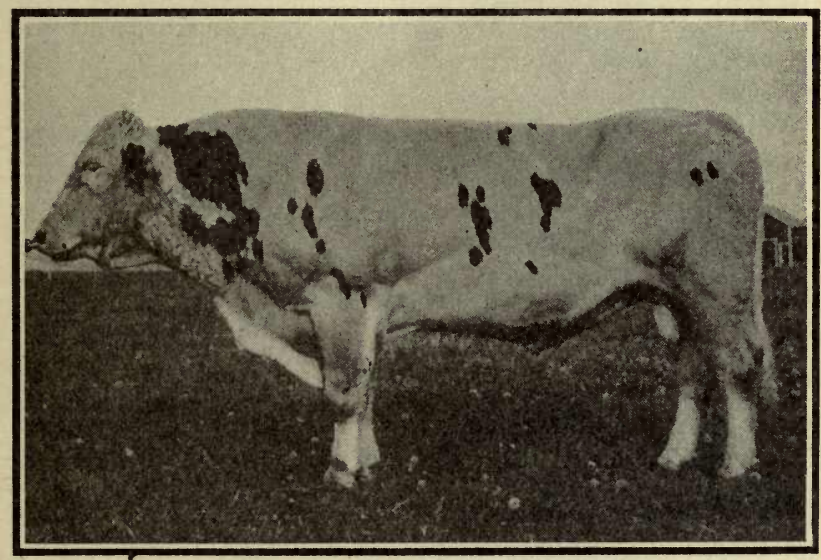

FIG. IO-HOLSTEIN FRIESIAN BULL "HENGERVELD DE KOL"

Teats are of large size, milk veins large, tortuous, and prominent.

The breed is famous for milk production. It is not uncommon for the Holstein to produce her own weight in milk in thirty days, and from ten to twelve times her weight in a year. Individual productions of over IOo pounds of milk in a day are well authenticated. From 8,000 to $I I, 000$ pounds is not an 
unusual average for a herd. There are many records of herds of from three to eight years of age averaging II,O0O pounds each for one year. One cow owned at Cuba, N. Y., is known to have produced 30,318 pounds of milk in 365 days. The percentage of butter fat is from 3 to 4.5 per cent. There are, however, many families of Holsteins that have made phenomenal butter records. One cow has a wellattested yield of $\mathrm{I}, \mathrm{I} 53$ pounds of butter in a year. This is the largest yield known up to the date of this writing.

While every breed of cattle may have its special adaptations and its special field in which it is most profitable, no other breed has spread so widely in those countries where no artificial barriers have been erected. The Ayrshire breed is scarcely known outside the British Islands; the Jerseys and Guernseys are not found to any extent upon the Continent; the Shorthorn is limited to a few localities in Belgium, France, Germany, while the Holstein-Friesian breed, with its offshoots under various names, is everywhere the prevailing breed in the lowlands of France, Belgium, Holland, and the western provinces of Germany.

Where the pastures are moist and nearly level the Holstein is at her best. She is, under such circumstances, the superior of any cow bred at the present time in the production of quantity of milk and milk solids. She does, however, readily adapt herself to side-hill pastures, and under all circumstances is a large and profitable producer for butter or cheese making or the production of milk for city use.

The Holstein cow Jamaica, No. 1336, H. H. R., is 


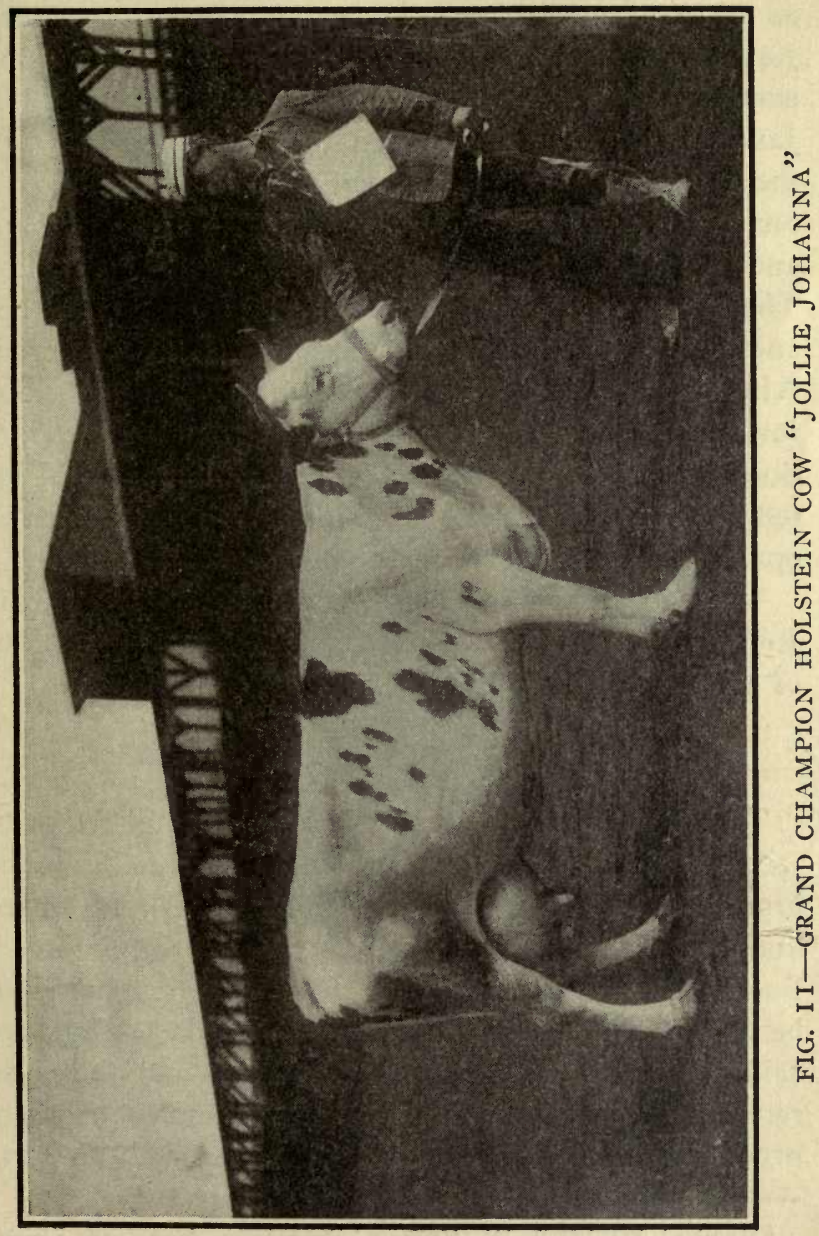


worthy of special mention. She came in in 1882 as a two-year-old, and in her first year produced 7,450 pounds of milk. Her first month's production exceeded all former productions for the age. In January, I884, she produced 73 pounds a day. In the following month she increased to 112 pounds 2 ounces in one day. She gave 535 pounds in five days, and for a whole month averaged 100 pounds a day. The owner of this cow was offered $\$ 15,000$ for her and her calf before she made her greatest record. After that event the offer was increased to $\$ 25,000$ for the cow and $\$ 10,000$ for the calf. Such productions are not the work of chance, but the result of intelligent breeding and painstaking care in the development of the heifer and the cow.

The bull Hengerveld de Kol (Fig. Io) and the cow Jollie Johanna (Fig. II) are splendid representatives of this breed.

\section{THE SHORTHORN OR DURHAM *}

The Durhams, now generally known as Shorthorns, were among the first of the high-bred cattle to be brought to the United States. They have been longer known to the breeder than any other dairy breed. Soon after the Revolution a few cattle, supposed to be Shorthorns, were brought to Virginia. They are said to have been well-fleshed animals and the cows remarkable for their milk production, some of them producing over thirty quarts of milk a day. In 1797

*Verified by John W. Groves, Secretary American Shorthorn Breeders' Association. 


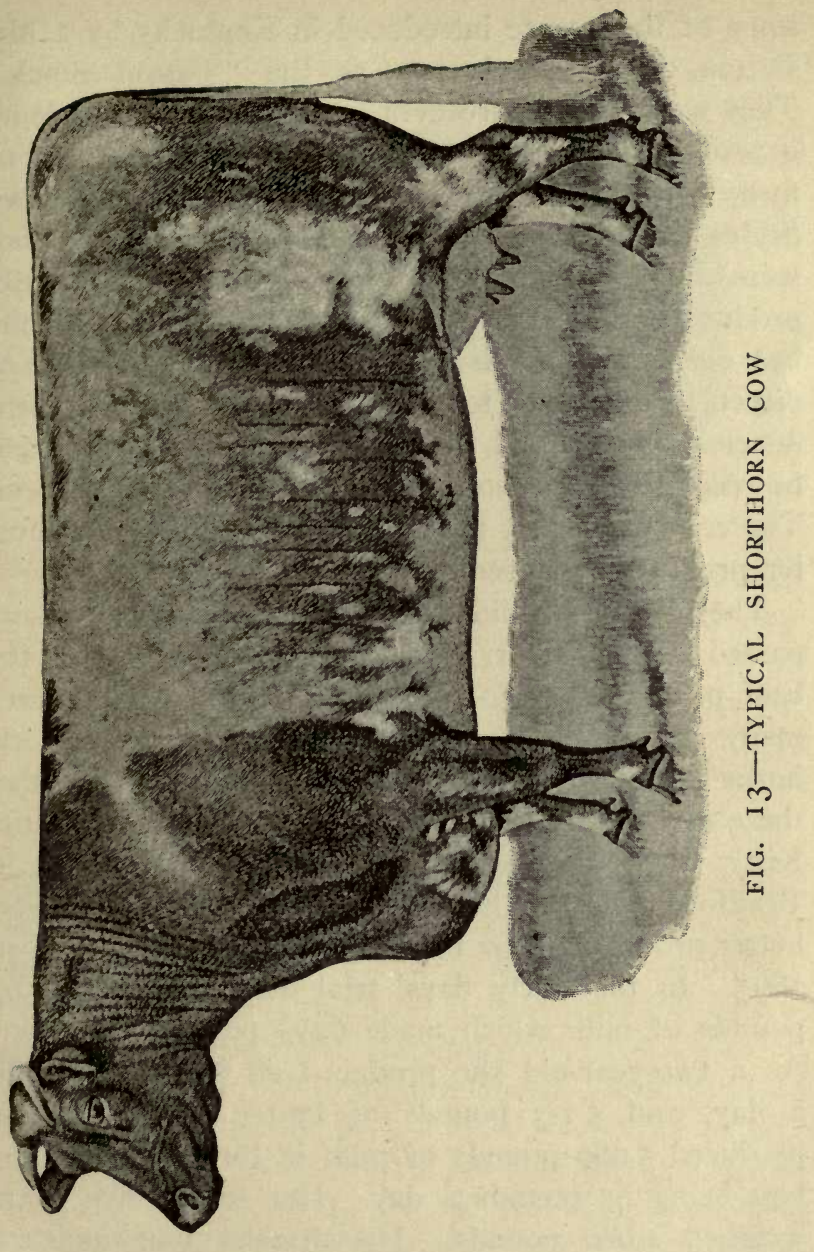


some of them were introduced in Kentucky by a Mr. Patton, and were known as the "Patton Stock." They were used as breeders, and their strain decidedly improved the cattle in the blue grass region. For many years the Shorthorn was bred in the United States as a milk producer. Among their number were found some of the finest specimens of milk producers in this country. About the middle of the last century many breeders of Shorthorns began to direct their efforts toward developing the beef tendencies of the breed, and this class of cattle came to be recognized as among the very best in that respect. The result was that their reputation of milk and butter producers was somewhat overshadowed.

They have splendid constitutions, and stand unsurpassed in their ability to assimilate food profitably for beef production. For the last quarter of a century many dairymen among the admirers of the Shorthorns have been developing the dairy type. To-day there are many herds doing fine work as dairy cattle. Kitty Clay, fourth, bred in New York, owned in Bradford County, Pennsylvania, was the champion butter-producing cow in the great test in Chicago in 1893. In the thirty days' trial her yield was 1,593 pounds of milk which made $62 \mathrm{r} / 2$ pounds of butter. As a two-year-old she produced 28 pounds of milk a day, and $5 \mathrm{I}-3$ pounds of butter. In $\mathrm{I} 895$ she produced 5,000 pounds of milk in three months, her best being 65 pounds a day. Her son at five years weighed 2,080 pounds. His dressed four quarters weighed 1,456 pounds. Kitty's weight at ten years old was 1,348 pounds. The Shorthorns are the 


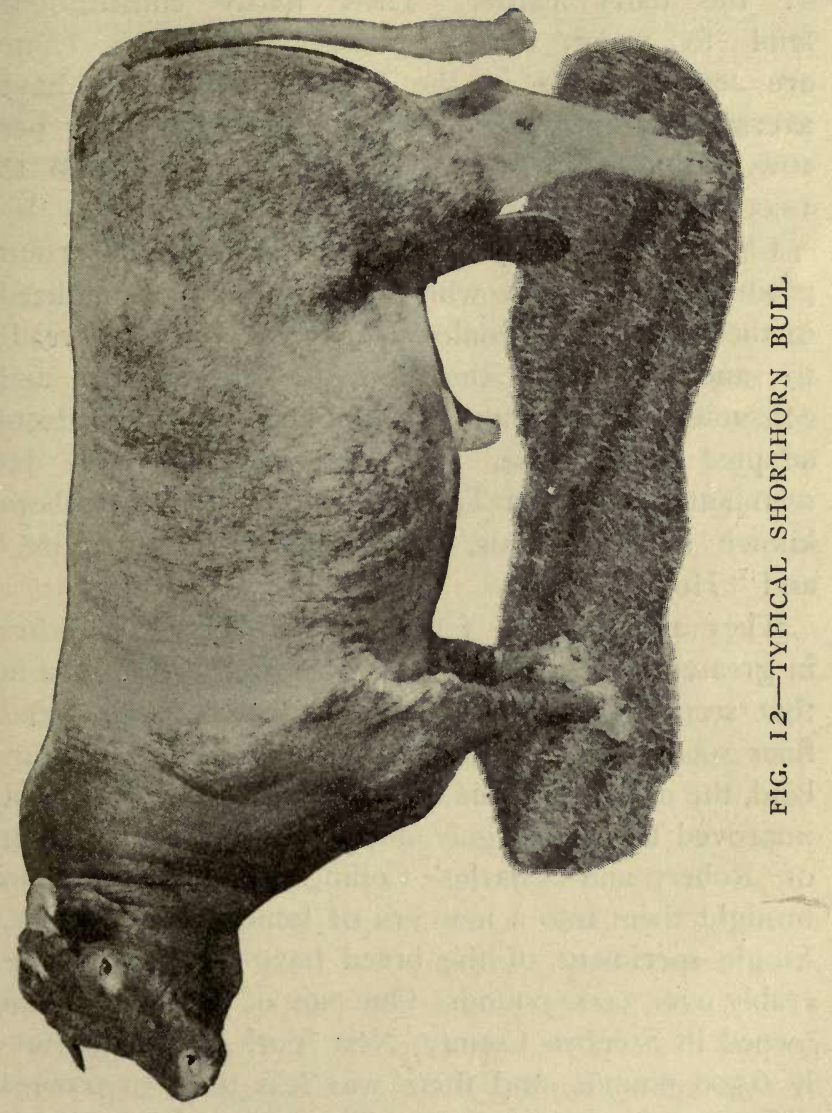

IIBRARI 
largest of the dairy breeds, if not of all breeds. They are more quiet and less nervous than most of the dairy cattle. Their hardy constitutions tend to make them persistent milkers. There are several herds in the United States that have averaged from 6,500 to 7,500 pounds of milk per cow. Single cows have produced from 10,000 to 12,000 pounds annually.

Calves from the Shorthorn cow form an important product of the dairy where skimmed milk is utilized in their feed. The males usually take on flesh readily, and are among the most profitable feeders and consumers of skimmed milk and other products adapted to their use. They are supposed to be descendants of the old Teeswater breed, and have been known as "Durhams," "Teeswater," "Yorkshire," and "Holderness."

They are, perhaps, found on the Western ranches in greater numbers than any other breed. Breeders in that section of country have, by selection, produced finer specimens than are to be found to-day in England, the native home of the Shorthorn. Their present improved form is largely due to the skillful breeding of Robert and Charles Colling, of England, who brought them into a new era of fame and prosperity. Single specimens of the breed have reached considerably over 3,000 pounds. One pair of Shorthorn oxen owned in Steuben County, New York, weighed nearly 6,500 pounds, and there was less than 50 pounds difference in their weight. The milk strains of this breed are rnore rangy and angular in form than the beef types. The udders are large, teats good size, 
skin soft and oily to the touch. The hair is usually short and fine.

Typical Shorthorns are seen in Figs. 12 and 13.

NoTE.-For much of the foregoing historical information I am indebted to the late Prof. Henry E. Alvord, of the Dairy Division, U. S. Bureau of Animal Industry, and Periam and Baker's valuable work. 


\section{SELECTION OF A BREED}

In selecting a breed the question to be answered is not how much some individual cow of the breed has produced, but what is the average product per cow of the breed under environment similar to that of the proposed herd. The purchaser must not lose sight of individual merit in the cow he is purchasing, as well as that of her immediate ancestors on both sides.

A man who expects to follow dairying as a business needs to employ the same enterprise that he would in any other business. It should be governed by the same rules that control trade generally. Lessening the cost of production and improving the quality of the product, in this, as in every other business, must be leading principles. The sole purpose in keeping the cow is for the conversion of feed into milk, butter, cheese, etc., at a profit. The use of paper and pencil will, in a moment, show the farmer the difference in producing value to him between the cow that produces 200 pounds of butter in a year and the one that, with the same care and feed, will produce 300 pounds. In ten years at 20 cents a pound he would be $\$ 200$ in pocket. An equal difference exists between the cow producing 4,000 pounds of milk and the one producing 6,000 pounds per annum. Dairymen of to-day have at hand the results of the labor of generations of careful and skilled breeders in the 
development of the specially bred cow. Such cows are now so plentiful and so easily secured, there is no longer any excuse for the existence of the scrub cow. She is rapidly becoming a thing of the past. While we cherish a kindly feeling for her memory, there will be none to mourn her loss.

In building up a herd, a dairyman must decide upon what branch of dairying he purposes to enter. In butter making he desires the cow that will, at the least cost, reduce feed to butter fat without regard to quantity of flow. If cheese, or condensed milk, then the cow that will best meet his requirements, whether for quantity alone, or quality and quantity combined. If for city or village delivery or special customers, where milk reasonably rich in cream and butter fat as well as quantity is important, still another kind of cow should be selected.

\section{ADVANTAGES OF SPECIAL BREEDING}

The great advantage of the specially bred cow that has in her veins the results of generations of breeding in a single direction is the prepotent power thus imparted, the power to impart to her offspring the same qualities which she has inherited from her ancestors. In this she greatly excels the ordinary native cow. As, shown by results, cows one-half, three-fourths, or seven-eights bred have a much greater proportion of the qualities of the full blood ancestors in their veins. The tendency to what is known as back breeding is much greater than is generally supposed. The chances are more than one in two that an animal will go back two or three generations for its predominating qualities. 
In breeding up a herd it must be remembered that the bull is half the herd. As a rule he is more than that. The breeder should never allow a few dollars difference to stand between him and the animal he thinks will make a satisfactory head to his herd. If he be financially able to do so, he will, of course, stock up his herd with the breed of his selection; but if not, he will proceed to build up the herd.

Having selected the breed best adapted to his purpose, the dairyman will secure the best pedigreed bull he can find-one whose form and general make-up stamp his as a getter of dairy stock. No greater error can be made than to allow mere size to control in his selection. As a rule, overgrowth is a mark of lack of dairy quality instead of merit. Under its appropriate head, "Dairy Form," this will be further treated. He must select the best quality of cows he can secure, native or otherwise, and upon them use the bull selected.

No bull should be used before he is sixteen or eighteen months old. From the heifers of this get the strongest and most promising (which does not always mean the largest) are to be bred again to their sire. The get of this cross may again be crossed from the same bull if he has proved to be a getter of good, vigorous stock. This latter get will then be three-fourths blood. Many successful breeders have made still another cross upon the same sire with good results. I am aware that this advice is contrary to generally accepted ideas of successful breeding, and is branded as incestuous breeding. This prejudice is purely a matter of sentiment and is not founded upon fact. On the plains it is a well- 
known fact that among the cattle and horses the strongest takes the herd and remains at its head until a stronger conquers him.

In thus closely inbreeding, care should be used. The direct result is concentration of the qualities of the sire, bad as well as good. If the sire be possessed of a marked weakness in any direction, this quality is likely to appear in the offspring in an increased degree. When found objectionable, inbreeding should be stopped, and another bull selected possessing as far as possible the same breed characteristics, and the breeding continued on the same line. This is called breeding in line, and is the only safe manner in which to develop a herd. By discarding the poorest and selecting the best, by the time fifteen-sixteenths bloods are obtained the owner will have a herd which will serve his purpose quite as well as full bloods.

Except as a matter of necessity, no cow that has been in milk should be purchased unless the buyer has a thorough personal knowledge of her. Intelligent dairymen do not part with their best cows for a price below what they regard them to be worth. They know the animals' qualities, peculiarities, faults, and characteristics. They know whether an animal is nervous, a poor feeder, uncertain, likely to dry off too easily, and all the other conditions affecting her value. If the buyer does not know these things he is at a disadvantage. If, however, he can learn the qualities of the dam and the sire and their ancestors he has a better knowledge of the conformation of the dairy cow than the man from whom he is buying; he has in the purchase of heifers that have never been in milk at least an equal footing with the man from 
whom he buys. A first-class heifer can be bought, before she has come fresh, dollars and dollars cheaper than after the owner has milked her for a season and has learned her true value. It is safer to buy the heifer before the owner has learned her virtues and vices than after.

\section{CROSS-BREEDING}

More valuable time is lost by those seeking to build up a herd for special purpose in pursuing that ignis fatuus, the "general purpose cow," than in any other way. It takes from four to eight years to breed a cow of any specified quality. This is too large a part of a lifetime to be lost in mere experiment.

Crossing a beef breed with a milk or butter breed neutralizes the best qualities of both. The result of years of effort is lost in the cross. The writer, after years of investigation and study, has ventured upon one cross, that of an Ayrshire father upon a Jersey mother. Both are bred for milk and butter. The Jersey for butter, and the Ayrshire for milk and butter. The breeds have much in common. The strong points of the one seem to supply the weak points of the other. The Ayrshire is possessed of a strong constitution and excellent digestive powers. Its butter-fat globule is small, light in color, and does not cream as readily as that of the Jersey. That of the Jersey is large, creams readily, is high in color, and produces an excellent quality of butter. The prepotency of the Jersey is strongest in this direction; that of the Ayrshire in imparting strong constitution and excellent digestive powers. 
I learned of two herds in Massachusetts of the cross-bred Jersey-Ayrshire that were averaging 400 pounds of butter a year per cow. Acting upon this information, I procured some of the best Jersey cows I could find and used them with a bull of satisfactory ancestry. The result has been heifers of a remarkably uniform quality in production. Eighteen of twenty heifers were perfectly satisfactory milkers; and, barring the cow Daisy, hereafter referred to, have proved themselves the best butter producers I have ever owned. Their milk production is from 30 to 50 per cent. increase over that of the full-blood mothers, with quality but slightly inferior thereto. For family use they are superior cows. They are attractive in appearance. So far as I have been able to learn, this is the only successful cross of dairy cattle that has been made. The cross of the Jersey with the Holstein has produced some excellent cows, but the cross, generally speaking, is worse than a failure. The types are opposite in almost every respect. The prepotent qualities of both breeds are lost in the cross. The cross of Jersey, Guernsey, or Holstein with the beef breeds is equally unsatisfactory. Steady and persistent breeding in one line and for a single purpose is the only safe rule for a dairyman to follow.

After having raised the standard of a herd by careful breeding comes the final and crucial test-to wit, individual selection. It is, after all, capacity of the individual demonstrated by actual test that fixes the standard of the dairy cow. By breeding the average the general chances may be vastly in- 
creased, and from the stock thus produced the cows for dairy work should be selected.

As assistants in making selections the scales and the Babcock test are indispensable. They are to the dairyman what the scales are to the grocer and the yardstick to the merchant. They are impartial. They fix the value of the cow as a part of the herd with inflexible accuracy. The cream test is better than none, but it is so variable and uncertain that it is of little value. It is not uncommon to find cows whose cream is twice as rich in butter fat as that of some others. I have known the difference to be so great that it took two and one-half quarts of one cow's cream to furnish the same amount of butter fat as contained in one quart of cream from another.

The milk of each cow should be weighed on the same day of each week. At the end of the year these weights will have a basis which will give a practically accurate result. The butter-fat test should be used once in two months. The data derived from these two tests will tell what the cow has done and is worth. The fat test should be of a mixture of samples taken from four consecutive milkings. A case made to hold eight or ten numbered eightounce bottles, each one used for a cow, is a handy means of lightening the labor of testing. An ounce capacity tin cup may be used to take samples from the milking to put in the bottles. Every time a sample is added it should be mixed thoroughly with what is already in the bottle. In a book arranged for the purpose a record of these tests must be kept. 
CHAPTER VII

\section{THE DAIRY COW AND THE DAIRY SIRE}

YEARS of breeding and of development in opposite directions have made the beef and dairy type almost distinct species. Among skilled stock raisers one-half the individual characteristics of an animal are attributed to heredity, the other half to environment. This latter part is the result of feed and surroundings, for which the owner is responsible.

The beef animal is possessed of a strong, vigorous external circulation developed to convert the elements of food into flesh, and place this on the ribs, etc. The milk and butter cow has a strong, vigorous internal circulation fitted to convert food elements into butter fat, casein, etc., and deposit these in the udder. The milk veins are the external evidence, and to a great extent a measure of the capacity of this internal circulatory power. In the beef breeds this feature is deficient. To be other wise would condemn a cow of the beef breed as a producer of good beef stock.

\section{THE DAIRY COW}

The milk veins of a dairy cow are well developed. There is often a difference among breeds and between individual cows of equal capacity, but in a first-class dairy cow these veins are always well developed. They enter the body well forward in large 
openings, and among the best of the Jerseys and Guernseys there are often two and sometimes three of these openings of branches that will admit the end of the finger. This strong interior circulation characteristic of the dairy breeds is always at the cost of the exterior circulation. It is a rare thing for a producer of large quantities of rich milk to be otherwise than thin in flesh. The cow Daisey (Fig. I4) was a cross-bred Jersey-Guernsey weighing I,IOO pounds. Her annual milk production was over I0,000 pounds of 5 per cent. fat milk. She had good average pasture and only a fair grain feed, at no time exceeding twelve pounds daily. When in milk she was never in better condition than she appears in the picture. Her maximum production was forty-five pounds a day.

Note the make-up as applicable to the dairy cowmuzzle slim; upper lip large, coming well down; nostrils wide and open; face, from end of nose to top of head, dishing; the same between the eyes; eye large and expressive; head devoid of flesh and the veins standing out clear and distinct; neck thin and well cut up under the chops (the loose skin partially conceals this in the picture); shoulders, at the top thin and sharp, slightly above the line of the back; back dropping slightly down behind the shoulders; hips high, prominent and wide apart; pelvic arch, just back of hips, well arched, prominent, and distinct; tail long and slim, but firm and strong where it joins the body, heavy brush at the end, setting on well front instead of back, as in the beef type; skin loose but firm, flexible, and thin; neck setting in the body at a sharp angle instead of by rounded, graceful lines, as in the 


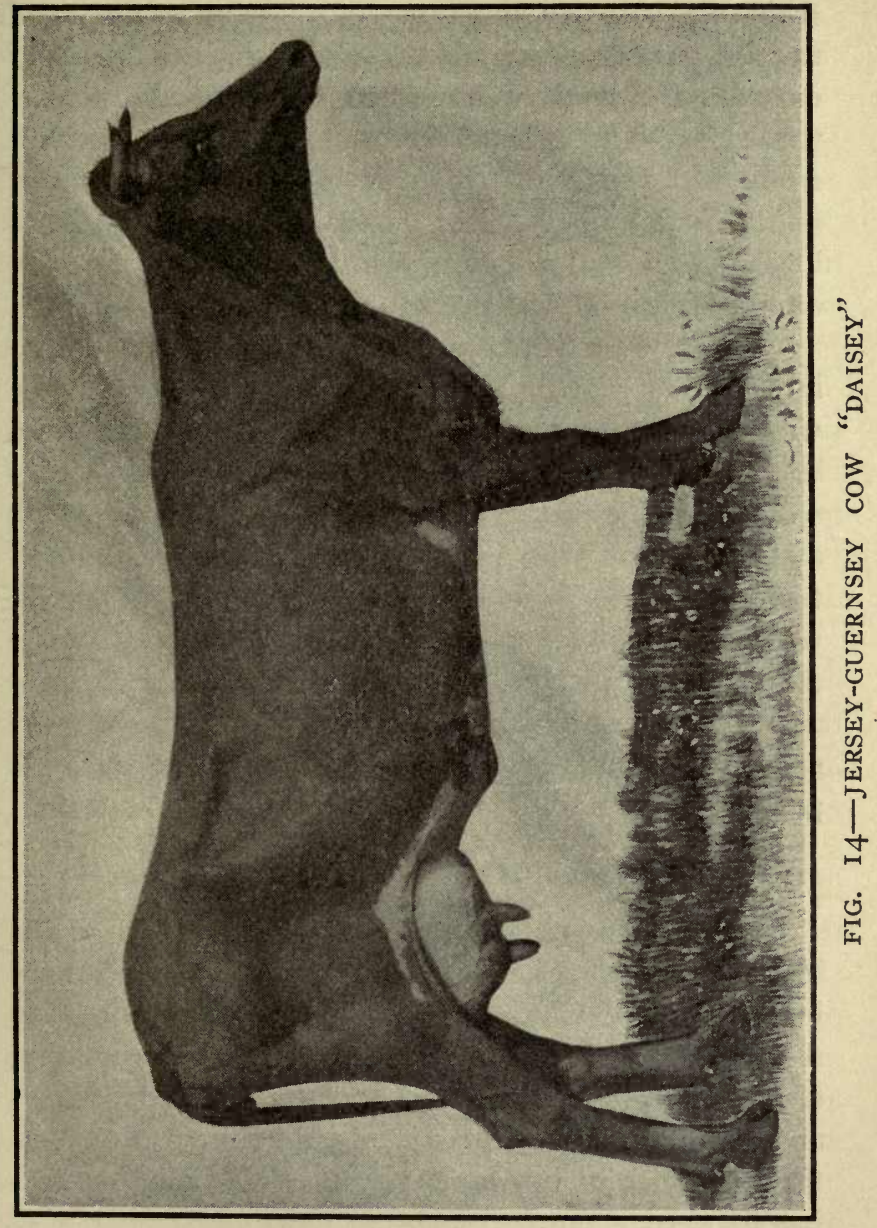


beef type; shoulders pointed and projecting well in front, almost to an apparent deformity; legs wide and thin, but firm, nervy, and strong, with veins standing out clearly; flank well arched and devoid of fatty tissue; same from hock to root of tail; udder well front and well up behind; escutcheon distinctly marked, running to and above the vulva; general loose, open conformation, characteristic of the true dairy type; milk veins large and tortuous.

Daisey when fourteen years of age, was still doing excellent work. While she was not so much of the wedge shape as most breeders like to see, she combined as many dairy qualities as any cow I have ever seen. Among these is the ability to produce milk and butter fat. She was good for 600 pounds of butter and 10,000 pounds of milk annually. She gave twenty-five pounds of milk within ten minutes of the taking of the picture. She was the result of no mere accident, but of persistent breeding for a special purpose. She came from a long line of butter and milk producers.

\section{SELECTION OF THE SIRE}

Much has been said about "heifer neck" in bulls, but the same leading feature should appear in the bull as in the cow. The neck should show strong masculinity and constitution, but be at the same time clear and distinct from the beef type. Dairy marks and make-up, instead of size, should rule in the selection, whether in buying to improve the herd or selling to weed it out.

Note the form of John Webb, (Fig. 15) Ayrshire Bull No. 5180 Ayrshire Herd Book, Chief Alvord, of 


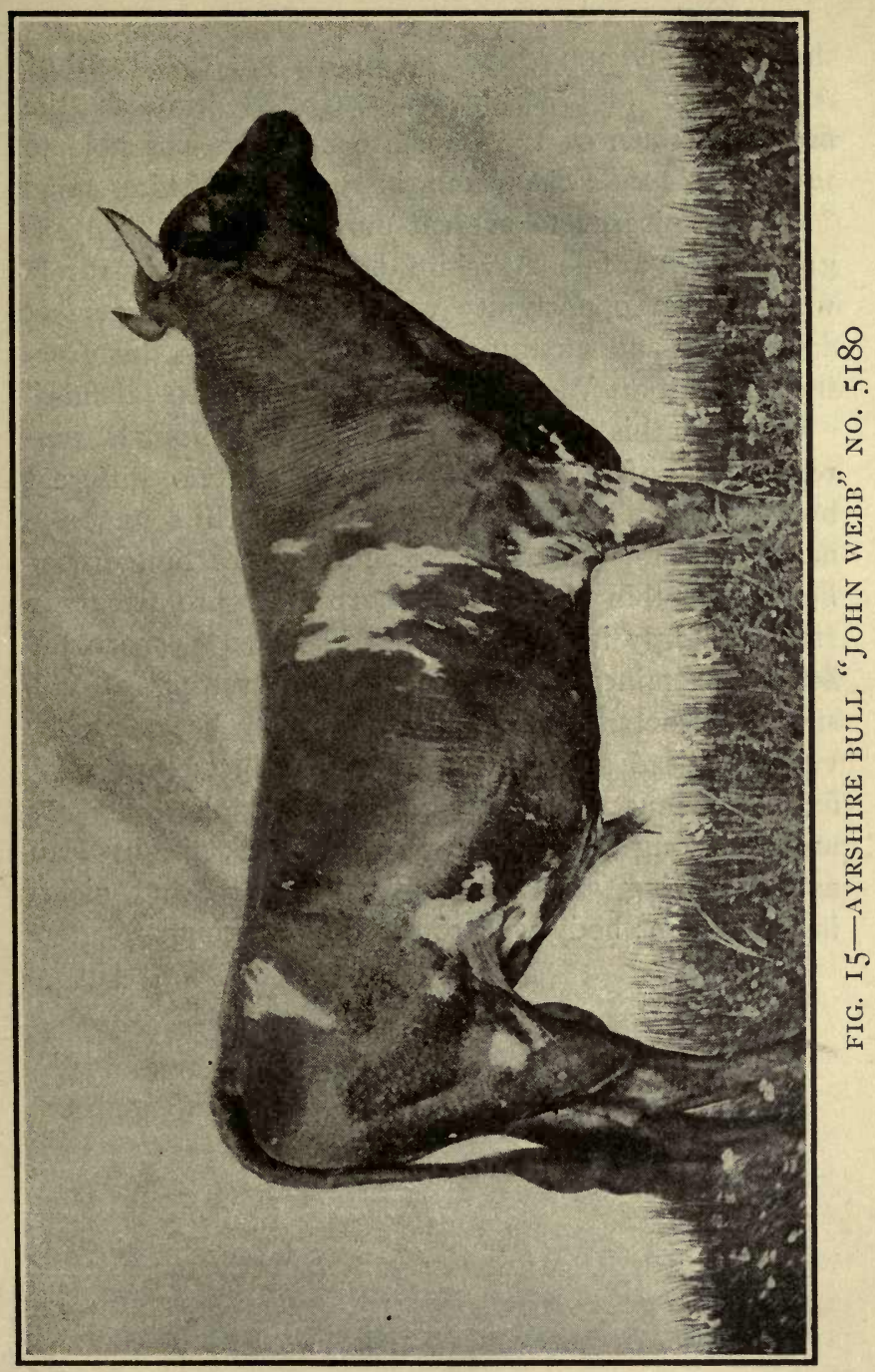

FBRART 
the Dairy Division of Animal Industry, Department of Agriculture at Washington, selected him as the finest specimen of the Ayrshire male he was able to secure. Hoard's Dairyman, in speaking of him, says : "We are pleased to present our readers with an engraving of a fine Ayrshire bull. . . . It is rarely we have an opportunity to present a more perfect dairy form and quality than is here seen in this Ayrshire bull John Webb. His weight is I,400 pounds."

Compare this bull with Daisey. These animals, representative of the two sexes and of two different breeds, have all the leading dairy marks in commonnamely, clean, thin nostrils; thin overreaching upper lip; high, thin shoulders, sharp and prominent in front; slightly incurving spine; high, wide, sharp hip bones; prominent pelvic arch; front setting of tail, strong at roots, but long, slim, and with heavy brush; veins on head and legs clear and distinct; legs wide, flat, thin, muscular as a race-horse; flank thin; hips arching, long from rump to hip-bone; thighs lean and incurving at rear line; loose, soft, and yielding, but firm; body well rounded and strong. 


\section{DAIRY STANDARD}

IN building up a herd a fixed standard should be applied to cows five years of age and over. In a butter-producing dairy that standard should not be less than 250 pounds, and in the milk-producing herd not less than 5,000 pounds annually. This, of course, means under favorable conditions. The cow should not be charged with the result of neglect on the part of her owner. If a heifer comes from good producing ancestry and is of good dairy form, she should not be discarded after the first, second, or even third, calf. One of the worst mistakes ever made by the writer was selling a fine, well-pedigreed cow at four years old because she did not come up to his expectations. The following year she became a cow producing between fifty and sixty pounds of milk daily on average pasture feed with a little grain. Among well-pedigreed, high-producing cows, ill or unkind treatment will make a greater reduction at the pail than with the scrub.

\section{REARING THE CALF}

The calf should be removed from the mother before it is a day old. If it is not well developed, with good teeth; if it is dainty and not inclined to drink, has a poor appetite and is generally offish, it will not be worth the raising. Feed three times a day with new milk, to which add a little hot water, for the first week or more, and give not much over a quart 
at a time. More calves are spoiled by overfeeding than by underfeeding. After the first week gradually substitute warm sweet skimmed milk for the full milk and add a little flaxseed or oil-cake meal. Prepare this daily by soaking five or six times the bulk of the meal in warm water until it becomes a jelly. Start with a tablespoonful of this, well stirred into the feed, slowly increasing the amount. Loosening of bowels or other indication of indigestion is proof that too much is being fed.

At the third week begin to add a little wheat middlings. At that time the feed may consist of warmed skimmed milk, oil-cake meal, and wheat middlings, with a little fine ground corn-meal added in winter. After the second week two feeds a day will do. Six quarts of milk a day with oil-cake meal and wheat middlings is abundant. A quart of hot water may be added to each feed to warm the milk. It is an easy way to warm the milk, and will be attended with good results.

As soon as the calf begins to eat hay, feed clover cut when it begins to blossom, and placed where available. Corn-meal should be sparingly fed in winter, but not at all in summer. In winter it should not form over one-third of the grain feed at any time. Corn-meal keeps the animal warm, and tends to fatten it. Milk, oil-cake or linseed-meal, and wheat middlings form blood, muscle, nerve, bone, hair, etc., and tend to develop milk qualities. All changes in feed for calves should be slow and gradual. Sudden changes in feed are likely to result unfavorably. In feeding grain, put the grain feed into the milk. Do not pour the milk on the feed. 
The quarters must be kept warm, and well supplied with dry, clean bedding. They must be comfortable if the calf is to do well. Never try to fatten; simply keep the animal growing nicely. The fat in milk has less feeding value than is generally supposed. Nearly all the protein, that substance which forms blood; nerve, and muscle, is in the skimmed milk. Feed regularly and by measure. Pet the calves. Keep them in separate pens while in a shed or barn in winter and spring. Calves do better in the barn than in the pasture.

\section{THE HEIFER}

Keep the heifer growing and in good condition. Clover, or mixed clover and timothy hay, ground peas and oats, and other nitrogenous food should constitute the winter ration. One-fourth to one-third cornmeal may be added, especially if the quarters are cool. Upon good management at this time depends the future cow. Her care and development up to the time of her first calf will go far to fix her capacity as a producer. Treat her kindly and keep her in confidence. Never speak to or treat her roughly, nor allow the hired man to do so.

When she comes in, milk her clean and pamper her appetite, so as to keep up the flow of milk until near second calving. If allowed to dry off early she will be hard to cure of it afterward. Four to six weeks is plenty long enough for a heifer to go dry. Accustom her to handling before she comes fresh the first time. Give the calves and heifers warm, comfortable quarters and comfortable, dry bedding at all times. 
Each generation of cows should be better than the preceding one. If this is not so it is the fault of the man. Lou Dillon did not trot a mile in $I: 581 / 4$ purely by inherited powers. None of her ancestors ever showed their capacity to equal her performance. Inherited powers are conceded to exercise a powerfu] effect; but increased power, developed by environment and training, must be added to make the twominute horse possible. The same is true of the heifer being reared. The raiser has as much to do with developing her into a profitable machine as the man who bred her; as much as her father and mother.

The properly reared heifer resulting from the cross of the Ayrshire father upon the Jersey mother can be depended upon at four years to produce 300 or more pounds of butter and 5,000 pounds of milk. 


\section{CHAPTER IX}

\section{FEED OF THE DAIRY COW}

The properly bred and reared dairy cow cannot help but produce milk and butter if her owner does his part. She cannot, however, "make bricks without straw." In a series of tests conducted by the different experiment stations in the United States as to feed for cows, it was ascertained that the nearer certain proportions in food elements were reached the more satisfactory were the results in economical production of milk and butter fat. Those elements are protein (which forms bone, nerve, muscle, and tissue) and carbohydrates (which produce fat and heat). These, with moisture extracted, form what was known as dry matter. More will be said of this hereafter. The proper proportion was found to be twentyfive pounds dry matter, of which 2.25 pounds were protein and 16 pounds carbohydrates daily. While there is a difference in the amount needed for individual cows, proportioned to their production and size, the ration of these elements should be preserved. For example: If the cow were fed twenty pounds of carbohydrates, or heat food, and only one and onehalf pounds of protein, she fell off in production, and there was a waste and consequent loss in carbohydrates. The same follows in any other disturbing of the ratio or balancing of food. The food prepared in this way has been known as a balanced ration. 
Other elements enter into the feeding problems, so that a mere balanced ration is not the only thing tc be considered. Cottonseed-meal, a highly nitrogenous food, has a tendency to create feverish conditions and is irritating in its nature. Oil-cake meal, another nitrogenous food, has exactly the opposite tendency. It follows that where the balance in ration is made uf of either of these feeds the result may not be satisfactory. The effect upon the system must be considered. Wheat bran and middlings are bulky. Buckwheat middlings are heavy and a concentrated food. Mixing these feeds produces a much better effect than when either is fed separately. Oil-cake meal and cottonseed-meal may be mixed with the same result.

The feeding problem must be carefully studied by the man who would feed successfully. No single food or ration can be adopted with profitable results. Clover hay and alfala come the nearest to a perfect ration of any single food. No chemist can tell the kinds of food to use or the proportions necessary to produce milk or butter. The cow is her own chemist, and it was only through her aid that the balanced ration was determined. Her tastes, her appetite must be taken into consideration in determining what she shall eat, and the quantity should be increased or diminished as she makes corresponding returns. Compounding rations will be treated under a separate head.

\section{WATER AND SALT}

When practicable it is well to have fresh water constantly within reach of the cow. Devices for this purpose in considerable variety are on the market. 
Salt should always be within reach also. Where cows are confined in stanchions there should be a partition in the feed-manger to every second cow. On this should be fastened a cast iron or other box; inside dimensions, about eight inches long, four wide, and two deep. Over the top at the end farthest from the cow should be fastened a strip of zinc or iron about an inch in width to prevent the cow throwing the salt out with her tongue. Salt should be kept in this box at all times. Now and then a cow will be found that will eat too much for her good. It may be necessary to stint her to three or four feeds a week.

\section{SILAGE}

Among the cheap modern feeds that go to make up a ration none, when properly fed, surpasses silage. It is a succulent food that aids in the digestion of other foods, materially increasing their value for the production of milk, butter, and beef. The partial fermentation which takes place in silage, after it is cut and stored, starts the process of digestion and renders it the most valuable of succulent foods. Many feeders depend too much upon silage as a balanced food, and feed from forty to fifty pounds daily; an ample ration is thirty to thirty-five pounds daily for the milk- producing cow. If eight to twelve pounds of hay and what oat or buckwheat straw she will eat clean be added to the grain food, a complete ration will be formed. No greater mistake can be made than to keep the manger filled with hay or straw. Give the cow only what she will eat; when she stops, clean the manger, and leave it so until next feeding time. 
Most skilled feeders agree that two feeds a day are better than feeding oftener. Some favor a light feed of hay or straw at noon, but the majority favor the two daily feeds. Buckwheat straw properly cured contains more food value than good oat straw. It has about 25 per cent. more protein than oat straw.

\section{BALANCING A RATION}

The table below shows the constituents of some of the feeds used in forming a balanced ration. A full list is at the end of the book. Wheat bran, wheat middlings, corn-meal, gluten feed, oats, pea-meal, cotton-seed meal, oil-cake are among the most available foods for this purpose. Nearly all, except cornmeal, are highly nitrogenous, hence must be balanced with corn-meal, which is low in protein and high in carbohydrates. The word "protein," "nitrogenous," and "albuminoid" all refer to the same elements which are commonly called "protein."

\section{PROTEIN}

This is the constituent food used to build up and keep in repair the working tissues of the body. In other words, it supplies the material for the growth of tissue. This includes blood, bone, flesh, and hair. Protein also forms a large part of the solids in milk. It is indispensable for all these purposes; no substance can take its place. If, however, more is fed than is needed for these various purposes, the excess is consumed like carbohydrates. 


\section{FAT AND CARBOHYDRATES}

These are so similar in their uses that in modern feeding tables they are classed together. They serve three purposes. First, they are consumed in the body to furnish animal heat. Second, their consumption furnishes motive force, energy, as coal burned under the locomotive boiler furnishes power. Third, the excess not consumed for the other purposes is deposited as fat in the body. An animal may be fed with an oversupply of carbohydrates in the shape of corn, and an undersupply of protein, and while laying on fat actually starve for want of material to make blood, nerve, and muscle. An instance which came under the writer's observation illustrates this. A farmer, having nothing for his team to do during the winter, kept them in the barn, feeding them on a poor quality of timothy hay, some oat straw, and a liberal supply of corn-meal. In early spring they appeared to be in fine condition, but when he hitched them up they soon became exhausted, and he was unable to get one of them home. In calling a veterinarian it was discovered that the muscle, flesh, and blood of the horses had been so impoverished as to produce the same result as actual starvation. On a balanced ration they soon recovered.

The feed value of fat is two and a half times that of carbohydrates. Skim-milk can be fed to milk cows to advantage. The place of twenty pounds of average mixed ground feeds can be taken by one hundred pounds of milk. It is worth twenty cents a hundredweight. The following table may be found of assistance in producing a balanced ration: 
Protein Carbohydrates

Per cent. Per cent.

Corn silage . . . . . . . . I.I

18.2

Alfalfa hay ........ 10.4

Clover ........... . . 6.4

43.0

Oat straw . . . . . . . . I.4

Timothy hay . . . . . . 2.9

Corn-meal . . . . . . 5.5

Buckwheat middlings . . . . 23.7

Pea-meal . . . . . . . . 16.8

Wheat bran ....... 1.28

Oats

9.2

Suppose a ration is being fed from the above products as follows: Silage, 30 pounds; clover hay, I2 pounds; oat straw, 6 pounds ; buckwheat middlings, 4 pounds; wheat bran, 4 pounds. The value of this ration may be calculated by removing the decimal point in the above table two places to the left. This will give the value of one pound. Multiply this num. ber by the number of pounds being fed of each kind, and add the results to give the total value of the ration. Thus:

Protein.

Silage .... 30 pounds

Clover ..... I2 pounds

Oat straw .... 6 pounds

Buckwheat ... 4 pounds

Wheat bran ... 4 pounds

Total protein

Carbohydrates.

Silage ..... 30 pounds

Clover .... I2 pounds

Oat straw $\quad 6$ pounds $x$

Buckw't middlings. 4 pounds $X$

Wheat bran ... 4 pounds $X$

Total carbohydrates
Pounds.

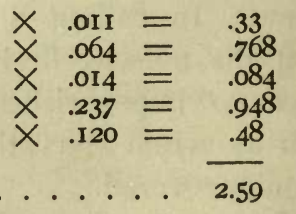

Pounds

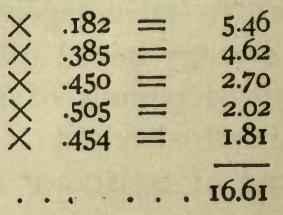


Following the above method, it is easy to ascertain the value of any ration being fed and how to correct it. This knowledge is indispensable in conducting a profitable dairy. Whatever the food, if the ratio of protein and carbohydrates differs materially from the formula of one to seven, one or the other is being wasted. This is only the ratio; the quantity and character must be governed by the demands, taste, and appetite of the cow. What each cow will consume at a profit can be ascertained only by actual experiment. Increase the grain feed as long as there is a corresponding increase in the flow of milk. Production of milk is a natural function. The cow's health will not be impaired by giving her all she will profitably eat and make into milk and butter fat. Under the above conditions the cow's period of profitable production will be greater than that of the neglected, half-starved, and half-frozen cow too often seen.

The ground feed should be scattered on the silage, so that both will be eaten together. By so doing the value of the ground feed will be considerably increased. Where cows are watered outside of the stable it is better to water them after eating. 


\section{CARE OF THE COW}

THe profitable work of the dairyman is in the care of the dairy cow. To do good work the surroundings must be to the cow's liking. She must have a warm, well-lighted, and properly ventilated stable. There should be a good-sized window every ten or twelve feet all the way around the stable. This should be as well lighted as the kitchen or sittingroom. There should be at least 800 cubic feet of stable space for each cow.

\section{LIGHT AND VENTILATION}

If a new barn is being built special attention in its construction should be given to ventilation, which must be under control, so as to avoid drafts all the year round. The following hints will be found useful in repairing an old stable, which may serve until a new one can be built.

Put in a goodly number of double-sash windows, made so that the lower sash will raise. On the inside of the window, dropping down tight on the casing and about four inches away from the window, nail a board about ten or twelve inches in width. When the window is raised to admit air, it strikes against this board, takes an upward draft, and gradually mingles with the air of the stable. On the leeward side of the barn open the windows in the same 
way, so that the foul air will pass out. A pure atmosphere can be kept in the stable in this manner without draft. Warmth can be obtained by lining the building throughout with heavy building paper, again lining that with old lumber from some torn down building. Stables should be thoroughly whitewashed at least once a year.

\section{CARDING AND BRUSHING}

Given a well-bred herd, a stable well lighted and ventilated, swing stanchions or other comfortable fastenings, a well-balanced ration, the intimate relation between the cow and her attendant begins. The cow has no means of retaliation for neglect or illtreatment, except to kick and to stop her flow of milk. These she is likely to use effectively. Kind treatment is always in order; regular feeding and milking times are among the first requirements. After these the most profitable operations in the barn and stable are carding and brushing. Repeated experiments have demonstrated that these practices, while the cows are in the stable, will increase the flow of milk sufficiently to pay the wages of the attendant. Three minutes to the cow will do the work well. For a herd of twenty-five cows the seventy-five minutes devoted to this work will result in more profit than an equal amount of time expended in any other way. An average difference of from two to four quarts per cow a day will result. One who has not tried this should divide his herd in halves, card and brush one-half daily, and let the other half go without for one month and note the result. 


\section{TEMPERATURE OF STABLE}

In winter the stable should be kept between $40^{\circ}$ and $50^{\circ}$ Fahrenheit. The latter is not too warm. This should not be trusted to the guess of the attendant. A thermometer should always be kept hanging in the barn at such a point as to give average temperature. Temperature and ventilation go together and should be carefully watched. The colder the weather the more rapid will be the circulation of air. The windows should be raised and lowered accordingly. Heat from the cows will keep the temperature all right when ventilation is well under proper control. 


\section{CHAPTER XI}

\section{MILKING}

So far as possible, the same person should milk the same lot of cows. No greater nonsense was ever promulgated than that all talking and whistling should be prohibited in the stable. The cow should be familiar with the voice of her attendant, and she should never hear it in other than kindly tones. She should be called by name, and talked to individually when he has occasion to speak to her. Whistling and singing to a moderate degree are not objectionable in the stable.

Mr. H. B. Gurler says that the cows invariably fell off in their yield under the care of a certain attendant. The man was kind, milked his cows quickly and clean, and seemed to give the same care as others. Still he could not keep up the flow of cows under his charge. It was noticed that he rarely spoke in the stable, and still more rarely to the cows he milked. His attention was called to the fact, and he was asked to change his methods and familiarize the cows with the tones of his voice. He did so, and the problem was solved. The cows had never become acquainted with him. Cows like to hear the voice of the attendant, especially when in a kindly manner he speaks their names.

Milking should be done quickly, kindly, and cleanly. If a part of the flow is left in the udder, each time, the cow soon learns to secrete just that amount 
less, and there will be a corresponding falling off in the flow. The same sequence of milking should be followed each day, so that each cow will know when her turn comes. Attendants have probably noticed that when they sit down to milk one cow the udder of the next one will begin to fill, and milk will often begin to flow from her teats before they get to her. If she is not milked in her order she will manifest her displeasure by her nervous actions, indicating disappointment. The first few streams of milk from each teat should not be put in the pail. Bacteria gather in the end of the teats between milkings. These in the milk will increase with great rapidity, often seriously injuring its quality for butter and cheese. As soon as drawn the milk should be removed from the odors of the stable. There is nothing that will more readily absorb noxious odors than cooling milk.

The cow is a creature of habit. If regularly fed before milking she will, when this order is changed, be restless and often refuse to give down her milk. It is better to feed after milking. If silage, at all defective, be fed before milking the odor is likely to appear in the milk. Odors from food reach the milk in an incredibly short space of time. Two minutes will serve to take the odors of food to the udder and milk-pail. If fed after milking, silage will not, unless very bad, taint the milk. Milking should be done at periods as near twelve hours apart as practicable, and at the same hours each day.

After the cow has fed and lain down she should not be disturbed more than can be helped. Good, comfortable bedding, such as barn-floor litter, chaff, 
and buckwheat straw, should be kept under her. Oat straw is good, but does not keep its place as well as the articles mentioned. There is no economy in stinting the cow in the matter of bedding, as no more is wasted when liberal bedding is used than when it is stinted. No dog should be allowed in the barn or about the cows, and the animals should never be chased or hurried. Ill treatment of this kind will be evident in the production. In winter turn the cattle out not more than an hour a day in mild weather; less time when colder, and in stormy weather not at all.

\section{BAD HABITS TO AVOID}

Jerking downward with the hand when milking is a bad practice. It is not uncommon to see a milker jerk a teat as if he were trying to separate it from the udder. Many a fine cow has been ruined in this way. After the attendant has carefully wiped off the udder with a piece of dry burlap or other suitable material, he should grasp the teat, milk slowly for the first few moments, then with a slight downward pressure force the milk from the teat. He will find that it requires less exertion to milk in the proper manner than in the old way. An attendant who will not reform should be promptly discharged or dismissed from the barn. Garget, injured quarters, lumps in teats and udder, deformed udders are common results of this violent jerking down when milking. Wetting the hand or teat is another bad practice. It is filthy as well as injurious. If the teat be feverish, sore, or cracked, a little vaseline will soften it. 
This is an article that should always be on hand in the cow stable.

Cleanliness should be a standard requisite in the dairy. Cows well bedded and daily carded and brushed will be in condition to produce pure milk. The udder should be wiped with a coarse, rough cloth. This cloth should not be allowed to become filthy. If necessary to bathe the udder it should be wiped dry before milking. 


\section{CHAPTER XI}

\section{WHEN TO HAVE COWS COME FRESH}

Cows coming fresh in October, November, and December will, if properly fed and cared for, produce 25 per cent. more milk in the year than they would on the same care and feed coming fresh in March, April, and May. There is but slight difference in the cost of feed. The reason is this: a cow naturally begins to fall off in flow when from six to seven months in lactation. A cow coming in in fall or early winter reaches this condition when pasture is fresh and feed good. This counteracts the natural tendency, and through June and July she will hold her own with the cow fresh in the spring. The fall fresh cow is ready to begin to dry off as she reaches the dry weather, short pasture, and flies of August and September. The cow fresh in the spring reaches this period at the same time that nature tends to diminish the flow. This tendency is aggravated by the surroundings. It is difficult if not impossible to keep up her flow. The flow of milk, materially diminished for three or four weeks, cannot be fully restored until she is again fresh.

Silage and soiling crops, such as peas and oats, alfalfa, millet, hay, etc., are of great assistance, but they cannot entirely counteract the effect of heat, short pasture, and flies. The male should be kept from the cows except when turned with them daily in the winter to secure cows fresh in the fall and 
winter. About December Ioth is a good time to begin to allow the bull with the cows. Nine months and ten days is the average period of gestation. This brings the first cows in near the ist of October. At that time most of the flies have disappeared, and fall feed is plentiful. The fall fresh cow not only produces about one-quarter more than the one fresh in the spring, but she produces a large portion of it at a time of the year when it is worth 25 to 50 per cent. more than it is in late spring and summer. This is especially true in localities where milk is produced for condensing purposes.

Where the location will permit of dairying all the year round to supply local butter trade, winter, or year round dairying, is most profitable. Customers are always willing to pay a few cents more a pound where the quality is prime and the supply can be depended upon. In order to hold trade of this kind it is absolutely necessary that the supply be regular throughout the year. When once a customer has acquired a taste for a certain make of butter he will soon prefer it to any other, provided it is of uniform quality and flavor. Three grades of salting will suit the different tastes, salt, medium, and quite freshone and one-half ounces, one ounce, and one-half or three-fourths ounce to the pound. In some instances the location is such that cheese-making is the only available market for milk. In such case, from March Ist to May $15^{\text {th }}$ is of necessity the season for freshening.

Farmers often say: "My barns are cold and unfit for winter dairying." In such case dairying is not profitable at all, and the sooner it is abandoned 
the better. They are feeding their cows for summer work. A cow that is not well wintered will not do justice to herself or her owner even in the summer. January feed and care has much to do with July butter. It is well not to have heifers come fresh before twenty-four months old, but as soon after that, if they be of average health and growth, as possible. Close observation for twenty years has satisfied me that the heifer coming fresh at two years is likely to make a better cow than the one remaining dry until three years old. Milk production by a heifer still growing tends to develop milkproducing qualities. During every moment of her growth she is fixing her future capacity as a milk and butter producer. If her energy be directed only toward the growth of tissue and fat she will not be as good a cow as if this had not occurred. The heifer must have care and be kept growing. The best cows I have ever developed were those that came fresh for the first time between twenty-two and twenty-eight months of age. 


\section{CHAPTER XIII}

\section{FEEDS AND THEIR VALUES}

\section{CLOVER AND ALFALFA}

IN regions where alfalfa can be grown it is one of the most economical of dairy foods. It is highly nitrogenous, being worth 75 per cent. as much, ton per ton, as wheat bran. Its yield is three to five, and sometimes as high as six, tons to the acre. Its growth is controlled by local conditions, and it is worth while for each farmer to learn whether his conditions are adapted for it. (The reader is referred to F. D. Coburn's book on Alfala for full information.)

In colder localities, where alfalfa will not grow, clover may be considered the most valuable crop. It derives nitrogen, the most valuable of fertilizers, from the air, and furnishes its own fertility of nitrogen as well as leaving large quantities in the soil for future crops. A ton of clover has nearly twice the food value for milk production that a ton of timothy hay has. The dairyman who can sell his timothy hay and buy clover at the same price, to take its place, is making money. As a rule, timothy hay sells for quite an advance over clover, so that two tons of timothy will buy nearly three tons of clover. In the exchange the farmer is nearly doubling his money for the trouble and labor of so doing. 


\section{OATS AND PEAS}

Among the farm crops adapted to dairying there are few more profitable than oats and peas combined. The peas should, on most ground, be put in by plow, disk-harrow, or seeder, at least four inches deep, and should precede the putting in of the oats by about a week. There should be about one and onehalf bushels of peas and two bushels of oats per acre. They make an excellent forage crop when needed in July and August. Crops can be put in a week apart for succession forage supply. When not needed for supplemental food in a dry time they may be cut to hay, just as oat straw starts to turn color; or they can be allowed to ripen and can be threshed and ground as a grain food. The peas contain nearly 19 per cent. of protein and 53 per cent. of carbohydrates. The straw is good as a roughage for cattle eating silage.

\section{MANURIAL VALUE OF FEED STUFFS}

This division of feed values as it relates to economical feeding has not heretofore been considered. If the herd is to be charged with the value of the feeds, it must also be credited with what it returns to the soil in fertilizing values. As a rule, the cow uses up in the process of producing milk, butter, and beef, and in keeping up her animal heat, about 20 per cent. of the potash, phosphoric acid, and nitrogen contained in her food. The remainder is manure.

A large amount in value of this product is contained in the liquid excretion. This is the most readily available for plant growth. On many farms all, or a great part, of this is wasted. The total 
value of the excretion from a well-fed animal, based on the current prices for manurial elements, to wit, potash at $\$ 4$ per hundredweight, phosphoric acid at $\$ 4$, and nitrogen at \$15-amounts to \$25 annually to each one thousand pounds of stock. These values are taken from the analyses furnished by the Pennsylvania Experiment Station. (See computation of rations for farm animals, page 78 .)

As the cow consumes one-fifth of the potash, nitrogen, and phosphoric acid, and excretes fourfifths, it follows that she should be credited with four-fifths of the valuation for every ton she consumes. These figures are an important item in the economy of the dairy. They should never be lost sight of in the dairy balance-sheet. In the aggregate it means the difference between profit and loss. Of the annual excrement of a cow, about two-thirds is voided in the stable or yard. If the liquid is allowed to waste, and the solids are exposed to the elements and deterioration from leaching, three-fourths of the fertilizing elements in the excrement are lost.

Suppose an annual per capita manure production of \$24. Two-thirds of this, or \$16 worth, is left in the stable or yard. But it does not follow, of course, that the farmer will secure a direct return of the $\$ 24$ worth of fertilizer which each cow makes, even if he saves it all. It would, however, cost him that amount to put back in the soil the elements contained in the excrement if he were to buy them at commercial rates. Still, in purchasing feeds their fertilizing values should be considered. They form just as important a part in dollars and cents as the feed value of the product. 


\section{CHAPTER XIV}

\section{CARE OF THE MILK}

AfTER the milk has been properly and safely delivered in the dairy-room the really skilled work of the dairy begins. The cow has performed her work. The responsibilities from that time on rest with the butter-maker.

There are two methods in common use in separating the cream from the milk: the gravity process and the mechanical separator. After years of experience and observation the writer does not hesitate in expressing a preference for the gravity process where the conditions are favorable for its use. In former times shallow pans were used, in which, under the most careful methods, a large percentageoften in warm weather amounting to nearly 20 per cent. - of the butter fat was lost. This process was later improved by surrounding the pans with an outer jacket, through which the water was allowed to circulate. For some years these pans were in great favor. They enabled the operator to control the temperature, independent of outside conditions.

Later some inventive genius and keen observer originated the deep-setting process. It operates on the theory that rapid cooling of the milk causes the cream or fat to rise rapidly to the surface. It also keeps the milk from souring and thickening, which condition prevents cream from rising. This process consists in putting the milk in cans about eighteen 
inches deep and immersing them in water below $45^{\circ}$. The deep-setting process is a great improvement over former methods. As a rule, not over 0.4 of I per cent. of butter fat is left in the skim milk. To be properly used, cold running water should be in the

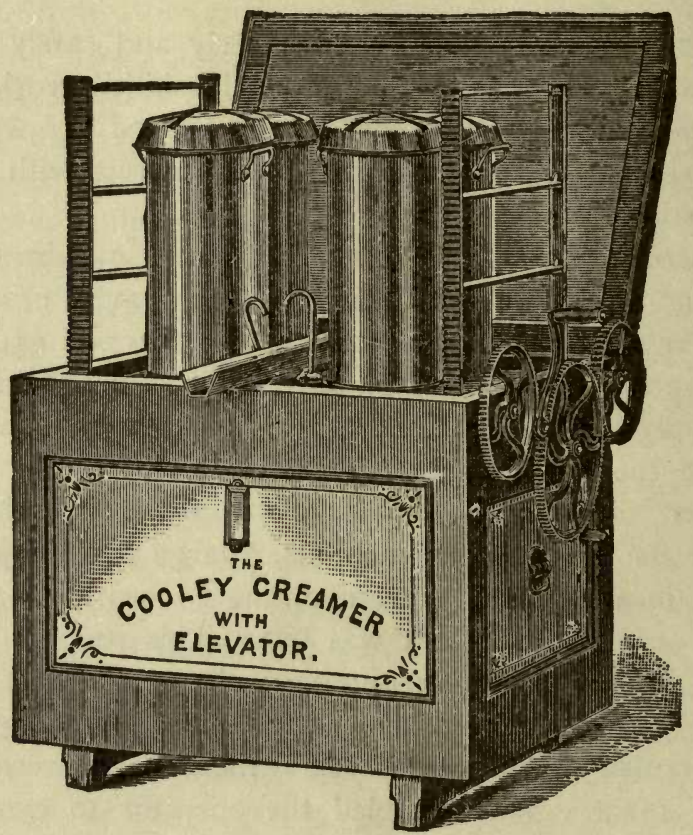

FIG. I6-THE COOLEY ELEVATOR CREAMER

dairy-room. Ice is also essential. An improved form of the apparatus used in this process is shown in Fig. 16.

Finally the centrifugal process came into use. It operates on the principle that casein, ash, and water are of greater specific gravity than butter fat, 
and that, if revolved rapidly, they will pass to the outside of the whirling column of milk, leaving the light or fatty part of the milk in the center. A means of discharge being provided for the outside

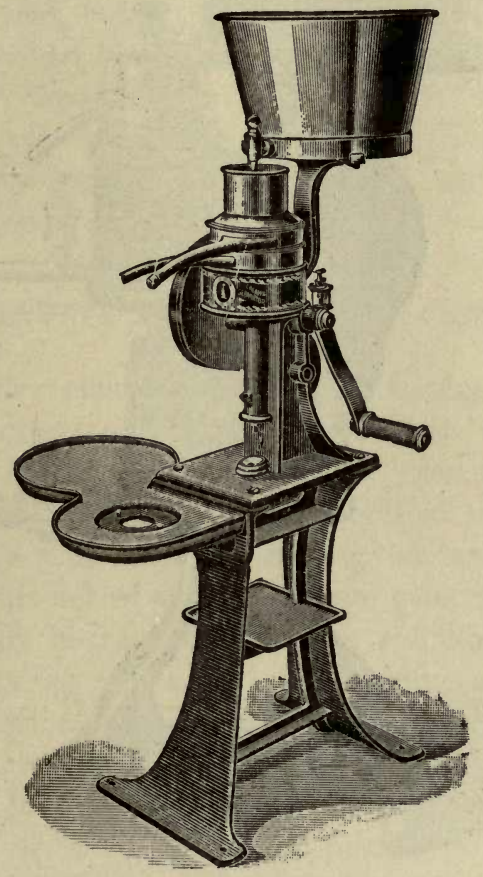

FIG. I7-THE DE LAVAL CREAM SEPARATOR "HUMMING BIRD"

of the column, and another for the inside, or center, the fat or cream will come from one opening and the skim milk from the other. Various inventions and improvements have contributed to make the centrifugal separator almost perfect in its opera- 
tion. Often not more than one-tenth of I per cent. of butter fat remains in the milk after separation;

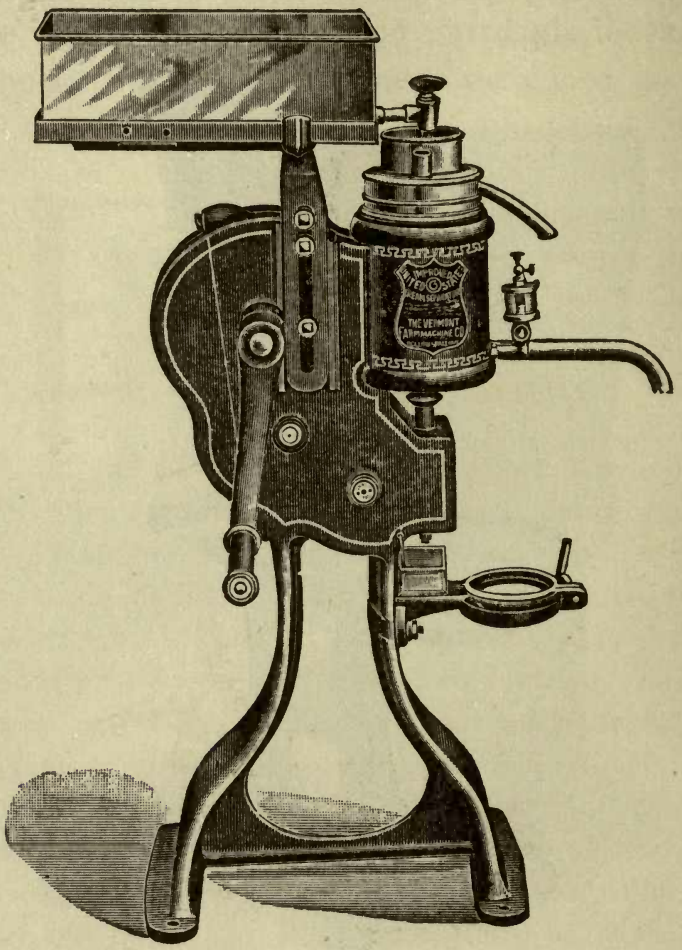

FIG. I8-IMPROVED U. S. CREAM SEPARATOR LOW SUPPLY CAN

that is, one pound of fat in one thousand pounds of milk.

These are great improvements on the methods used in the days of our fathers. They have added a large per cent. to the possible profits of the 
dairy. Among the advantages of the centrifugal separator is that of having warm skim-milk for the calves. An owner of one of the first of the centrifugal separators informed a guest at his breakfast-table that butter on the table was made from milk which had been taken from the cow that morning. The cream was churned sweet in order to show the wonderful advancement in scientific dairying. Forms of leading separators are shown in Figs. 17 and 18.

\section{GRAVITY SETTING FOR CREAM}

The writer claims the credit of having originated a new method for raising cream by the gravity process. By its use the milk is creamed as perfectly as by the best separators and at less expense. Some years since he was raising his cream by the ordinary method of immersing the cans in ice-water. One August he ran short of ice, and had to economize in its use. He had been using a large vat, or box, lined with zinc. In this he put a water-tight partition across the middle, and ran spring-water into one end. Ice was put in the water in the other end. The cans of milk were first placed in the springwater, which was at about $54^{\circ}$. After cooling to that temperature they were carefully lifted into the ice-water, so as not to disturb the rising cream. The only object sought was the saving of ice. But on the first morning the cans showed more cream than had previously been obtained from the same cows. To make sure he mixed two cans of warm, fresh milk, and put equal quantities back into the two 
cans, setting one in the ice-water and the other in the spring-water. After two or three hours the one in the spring-water was transferred to the icewater, with the same result as before. The next night four cans of milk were mixed in the same manner and the previous experiment repeated, with the same result. Three samples of milk from each can, the first from an inch below the cream line, the second from the middle, and the third from an inch below the bottom of the can, were tested for butter fat. In the double-setting cans the first sample contained but little fat; that from the singleseitting can showed the milk rich in fat. The sample from the single setting showed 4-IO of I per cent.; that from double setting, only a mere trace-less than I-20 of I per cent.

The double-setting process was at once adopted. Repeatedly tests have shown rarely over I-2O of I per cent. fat after twelve or fourteen hours' setting. Ordinarily the milk is allowed to set from sixteen to eighteen hours, but fourteen hours' setting is sufficient. The author believes that better butterbutter which holds its grain and flavor better-can be made by the gravity process than by the centrifugal method.

A very neat argument is made by separator agents who display the filth, or "separator slime," gathered by the separator, and say: "See what we clean from your milk That goes into the butter under the gravity process." But does it? It goes to the outside of the separator because it is heavier than the butter fat or the milk. Cream rises in the milk because it is the lightest substance in it. The same 
law that takes the filth to the outside of the separator would prevent it rising with and into the cream. Its tendency is downward. At the writer's suggestion an experiment was made at one of our experiment stations. This proved that gravity process cream is as clean as that produced by the centrifugal process. Gravity process carries less casein, ash, etc., into the cream than the separator process. This discovery of an improved gravity method of raising cream and another in cream ripening, to be mentioned hereafter, the writer considers as important advancements in the art of butter-making.

\section{RIPENING OF CREAM}

Bacteria are the dairyman's best friends. The science, or knowledge, of bacterial growth as applicable to the dairy has become a matter of practical utility at a comparatively recent date. Thorough knowledge of it is, however, an important branch of the dairyman's education. How to develop and encourage the growth of the desirable, and prevent the appearance of the undesirable, are important points for the dairyman to know.

Bacteriologists inform us that germ growth in milk is very rapid. Bacteria increase in geometrical ratio, doubling their number under favorable conditions several times every hour. Undesirable bacteria are but another name for filth. Where they get the start of the dairyman no prime dairy product can be made. They abound in poorly kept stables and on unclean cows. Hundreds of thousands of them drop into the milk-pail from the teats, udder, and body of an 
uncleaned cow during milking. They are too small to be seen by the naked eye, but their work soon becomes apparent to the taste and smell. They may be, to a great degree, eliminated by whitewashing the stables, keeping the cobwebs and dust and dirt swept out, carding and brushing the cows, and using good clean bedding. The end of the teat furnishes a home for bacteria, and the first few streams of milk from each teat teem with them.

A temperature of $50^{\circ}$ is most favorable to the growth of bacteria. Where the temperature of cream or milk is kept below $50^{\circ}$ the growth of bacteria, desirable and undesirable, is retarded. It nearly ceases at $45^{\circ}$. The effort of the dairyman must be to prevent the presence of filth bacteria. To accomplish this the first and last rule is cleanliness. It was a great discovery to find that the ripening and curing of cream is caused by the growth of bacteria, the germ of ferment. It is the key to the solution of many of the difficulties met in the manufacture of butter.

If the ripening of cream is merely another name for the growth of bacteria, it follows that there is a period in the ripening when the cream will make butter of better grain and flavor than at another time. It also follows that cream twelve hours old cannot be mixed with that twenty-four hours old, thirty-six, forty-eight, sixty, and the mixture be called twentyfour-hour bacteria, any more than a mixture of corn, oats, and peas can be called corn. The reasoning man at once determines that the cream must be kept cold and sweet until enough has been accumulated for a churning: then ripened all in one mass as 
rapidly and as perfectly as experiment and experience direct.

\section{KEEPING THE CREAM SWEET}

Until the commencement of the ripening process immersion in ice-cold water is all that is needed to keep the cream sweet as successive skimmings are added. Cream may be kept sweet in this manner for three or four days in summer without injury. If perfect butter is to be made the cream must be ripened in one body. If several cans of cream, taken from the same body, be set in a room kept at a uniform temperature, they will not all ripen together and reach the proper condition for churning at the same time. There will often be four or five hours' difference. In the ripening of cream there is a point at which, if churned, butter of a delicate nutty flavor can be secured. If churned too soon or too late this is lost. The result is a loss of several cents a pound from the market value of the product.

\section{A STARTER}

It has already been stated that the ripening of cream is the development of the bacteria of fermentation. Perfect butter depends largely upon this development being perfect. In all cream there are more or less foreign bacteria detrimental to the production of first-class butter. It is important that the proper bacteria be developed rapidly and ahead of the other forms existing in the cream. To do this the cream ready to ripen should be thoroughly inoculated with the proper kind of bacteria, instead of awaiting the slower process of natural develop- 
ment. To produce this effect, what is known as a starter is used. The most approved method of using this is as follows:

Put a quart or more of milk from a cow as nearly fresh as possible, and after the animal has been partly milked, in a clean glass jar, and set it in a reasonably warm place, suitable for ripening cream, from $65^{\circ}$ to $70^{\circ}$, and wait for it to sour to about the thickening point. If somewhat thickened it will do no hurt. There should be from 3 to 5 per cent. as much starter as cream. Take the amount of good, sweet skimmed milk necessary for the amount of starter needed, and heat it to about $180^{\circ}$ for fifteen minutes. This kills all forms of germ life. Reduce the temperature to about $70^{\circ}$ and add and stir in the starter made in the glass jar, which must be covered with a cloth to allow the gas generated to escape, and at the same time keep out all dust and bacteria floating in the air. The liquid should be stirred occasionally and allowed to stand until nicely soured to about the thickening point, when it is ready for use. Put this in the cream that is ready for ripening and stir in well.

A quart of starter to twenty or twenty-five of cream is enough, but less will do. The cream should be warmed to $62^{\circ}$ or $65^{\circ}$ in summer, and three or four degrees warmer in winter, and the whole mass thoroughly stirred every few hours until the ripening is complete. Cream is properly ripened in from eighteen to twenty-three hours. But curing is not to be measured by hours. Condition is the sole guide. 


\section{CHURNING POINT}

There are several practical tests to be used to determine the churning point.

Taste.-The cream should be just slightly acid, enough to give a clearly defined acid taste, but not what would be called sour.

Appearance.-At the churning point the cream will have the smooth, velvety, shiny appearance which comes just prior to the actual thickening. Wrinkles will form ahead of an instrument or paddle slowly passed through the cream.

Texture.-At the proper point of fermentation for churning, if a dipperful of the cream be taken up and poured back it will cut a smooth hole in the body of the cream, like oil or molasses, and will not spatter.

All of these conditions should appear about the same time. The oily pour will come slightly in advance of the others. The taste is among the most reliable tests, but all should be considered. 


\section{CHAPTER XV}

\section{DEVICE FOR RIPENING CREAM}

IN storing and ripening cream the control of temperature is of vital importance. It is, at the same time, a matter most difficult to master. One authority says: "Keep your cream cold until ready to ripen the whole churning, then raise the temperature to $62^{\circ}$ and keep it there." Another told how he keeps it cold, and then raises the temperature by setting the cans of cream in a vat of warm water until the cream reaches about $62^{\circ}$. How to do this he did not state. Steam, which must stand at $212^{1} 2^{\circ}$ in order to be steam, will not maintain an even temperature without constant watching and regulating.

The author then tried a plan of his own. He made a box about three feet square and high enough to contain the cream-pails. This was set on legs about eighteen inches high; in the middle of the bottom a hole, a foot or more square, was cut and covered with sheet iron tightly nailed on to prevent outside odors entering the box. A false bottom, one inch above the true bottom, was then put in. In this holes were bored all about the outside edges, but none in the middle, to insure circulation of the warm air. A small iron oil-stove was placed under the iron-covered opening. Then a hole was cut in the side of the box and covered with glass, behind which was a thermometer. The apparatus was a partial success, and a great improvement over former 
methods; the flame could be regulated and the temperature controlled quite well.

However, two difficulties arose. Although the cans of cream were at the same temperature, they would not all ripen at the same time. Second, air is too variable a medium for transmitting the heat; it heats and cools too quickly, and requires too close watching. By substituting warm water for warm air, and substituting a cream-vat for the cream pails, these difficulties were overcome.

An apparatus, consisting of a wooden box, was made, $47 \times 24 \times 18$ inches. At the corners legs were fastened, so that the top of the box stands 34 inches high. The vat is $36 \times 12 \times 16$ inches. The top of the vat is fastened to a frame-work with sidepieces long enough to extend four inches beyond the sides of the box when resting upon it. The pieces of this frame-work to which the vat is fastened are I $\times 2 \frac{1}{4}$ inches. These stiffen the sides and edges of the vat, making it substantial. A space of about four inches is left between the vat and the sides of the box and $2 \frac{1}{2}$ or 3 inches between the bottom of the box and the bottom of the cream-vat. The box is lined with heavy zinc; galvanized iron will do as well. The vat is made of heavy tin with rounded bottom, which form is much preferable to a flat bottom for many apparent reasons.

A hole sixteen inches square is cut in the bottom of the box, through the wood, exposing the metal lining. The edges of the wood about this opening are covered with asbestos packing, to protect it from catching fire. The legs are high enough to bring the bottom of the box about eighteen inches from 
the floor. One end of the vat comes close to the end of the box. At the other end is a space of several inches for the admission of ice when needed. Ice can also be put in the four-inch space at the sides. The top of the vat is thus about two inches above the top of the box, for the frame of the vat to fit into to keep it in place. A lid is attached to each side of the box by hinges, so as to drop against the side of the vat and close the space between the vat and

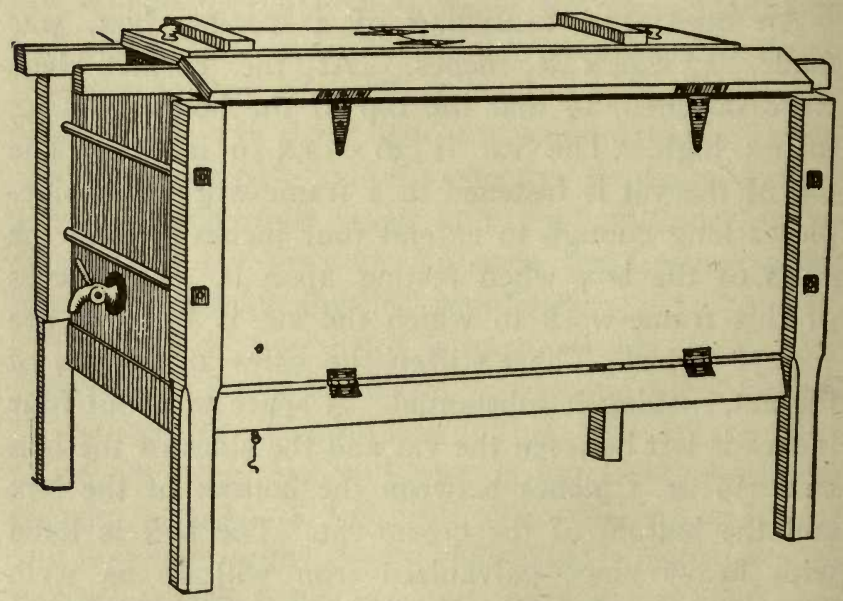

FIG. I9-FRONT VIEW OF CREAM RIPENER

the box tight at the top. The same is done with the end, so as to close the space between the box and the vat all the way around. At one end at the bottom of the box a faucet is fitted, from which to draw off the water. At the other end another faucet is connected with the cream-vat. This is made with screw couplings and packed so as to allow it to be 
removed when cleaning is necessary. This faucet should be smaller than one inch bore. It is a convenience but not a necessity, as the cream can be dipped.

The cream-vat should be covered by a lid, jointed in the middle with hinges, so as to be turned back at either end; or, better still, it may be covered by two or more thicknesses of cheese-cloth. In warm weather this should always be used as a cover for the vat. The lids will drop down and hold the cloth in place. Some strips should be nailed to the legs around the bottom of the box, projecting three or four inches below it. This forms a chamber which retains the air heated by the oil-stove. The whole should be substantially made and the woodwork should be well painted. A small three-chimney oil-stove, costing about $\$ 1.50$, blocked up so that the top of the burner is within an inch or two of the bottom of the box, will furnish the necessary heat. One of the heat-retaining strips on the bottom of the box should be hinged so that the stove can be put under. A front view of this apparatus complete is given in Fig. 19, a side view in Fig. 20.

By using ice in summer and cold water in winter this device will keep the cream at a temperature below $50^{\circ}$. When enough is secured for churning, the oil-stove and warm water control the temperature of the cream while ripening. This cream-ripener has simplified one of the most difficult problems in winter dairying. The operator soon learns how to regulate the blaze in the stove so that he can leave the ripener all night, and find in the morning the temperature had not varied more than a degree or 
two. It requires attention not oftener than once in two or three hours during the day. With a proper starter the cream will ripen for churning in about eighteen hours.

When sufficient cream has accumulated for a churning, the cold water should be partly drawn

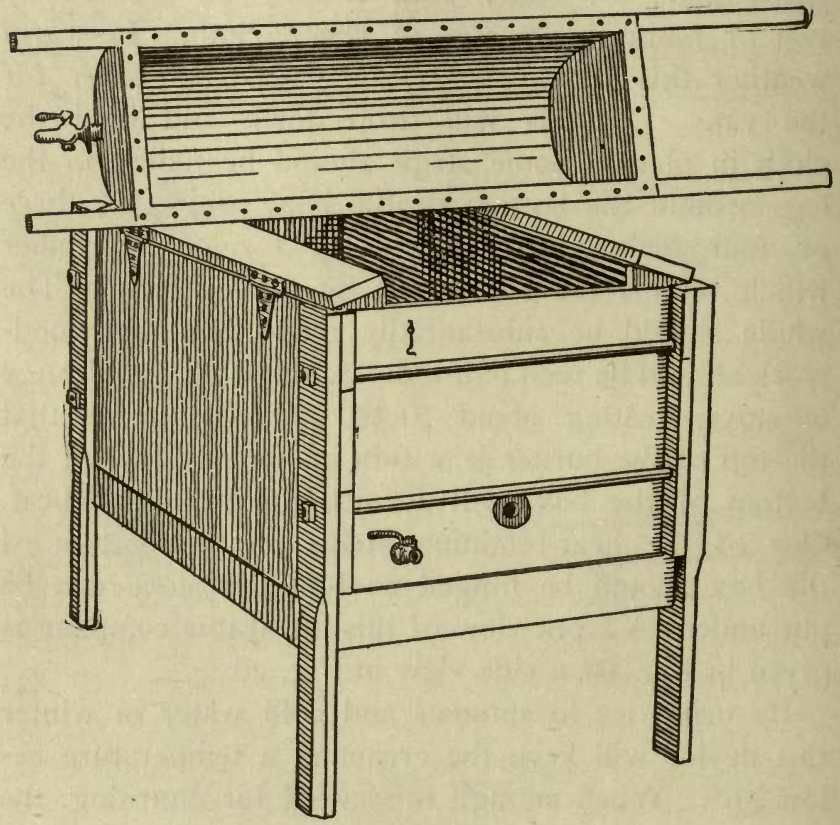

FIG. 2O-SIDE VIEW OF CREAM RIPENER

off, and enough boiling water added to bring the temperature up to the desired point, about $160^{\circ}$, but not so as to touch the bottom of the vat. This warm water coming in contact with the vat would heat the cream at the point of contact and injure 
it. Over the exposed portion of the metal bottom must be placed a piece of sheet or galvanized iron about eighteen inches square, with supports at the corners and one in the middle, so as to raise it about an inch. The corners of this piece may be turned down an inch for corner supports, and a small block nailed to the center for support at that point. This is to prevent the heating water from rising and coming into direct contact with the bottom of the cream-vat. It is an essential part of the ripener.

When the stove is lighted a vapor at once begins to rise and surround the cream-vat. If the cream be frequently stirred the desired temperature for ripening will soon be reached. Cold water should be added from time to time, as it is heated, until the warm water is nearly as high on the outside of the vat as the cream on the inside. Then the blaze should be turned down until there is just enough to keep the water at the proper temperature. The temperature of the cream will be two or three degrees below that on the outside of the vat. The water must be kept at a temperature to maintain the cream at the proper point-to wit, from $62^{\circ}$ to $70^{\circ}$, a little cooler in summer than in winter. Temperature at exactly $62^{\circ}$ is not as important as is generally supposed.

The cream should be stirred from time to time in the process of ripening the last thing before retiring at night and the first thing in the morning. If, when the cream has about reached the churning point, the water be partly drawn off and enough hot water added to bring the temperature up to about $85^{\circ}$, and be left at that point about fifteen 
minutes and then cooled, by adding cold water until reduced to $60^{\circ}$, it will churn much more readily and perfectly and the quality of the

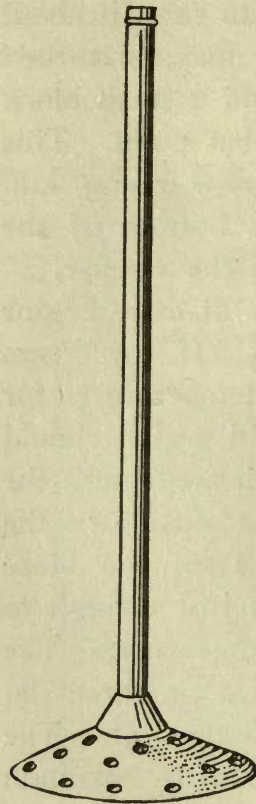

FIG. $2 \mathrm{I}-$ butter will not be impaired.

On one occasion when the author was using the hot-air ripener the temperature was accidentally allowed to get to $85^{\circ}$. The whole churning was supposed to be ruined, but the temperature was reduced to $60^{\circ}$ and the cream churned. It produced excellent butter. After that, raising the temperature in this way has been tried with success. The appliance described, with proper conditions, renders winter dairying as easy as summer dairying. It places the temperature of the cream absolutely under the control of the operator at all seasons of the year. Silage, clover hay, the Cooley can, and water creamripener control the question of butter-making at all times of the year. CREAM AGITATOR As perfect butter can be made in January as in June.

\section{A CREAM AGITATOR}

The cream agitator, illustrated herewith, works perfectly. A similar one is advertised by some supply house at twenty-five cents. It is made of medium weight tin, slightly conical in shape, like a saucer bottom side up. The disk is about nine inches 
across. At the apex is fastened a tin handle of convenient length, about twenty-four inches. The disk is punctured full of half-inch holes, as shown in Fig. 21. As the agitator is pushed through the cream, back and forth, it cuts the cream and prevents lumps from forming, and stirs more thoroughly than the paddle or large spoon. It is an instrument that, for the purpose, would be hard to improve upon. 


\section{CHAPTER XVI}

\section{CHURNING}

CHURNING is something more than a mechanical process. Properly ripened cream will churn in nearly the same space of time for each churning. The introduction of the concussion churn did as much for this branch of the dairy as the invention and improvements in other departments have done for them.

Some fifteen or twenty years ago a concussion barrel churn was advertised which was claimed would not only produce better butter than the old method, but more of it from the same quantity and quality of cream. The manufacturers sent the writer one on trial, with privilege of returning if not satisfactory. On its arrival the cream was weighed and put in. The milk from which the cream was raised and the butter also were weighed. The same process was followed with the cream churned in the old dash churn. There was a difference of 12 per cent. in the amount of butter produced. The test was repeated for three separate alternate churnings in each churn, with substantially the same results. The Babcock butter test showed the missing butter fat to be in the buttermilk from the dash churn.

There are many varieties of the concussion churn. 
The barrel churn gives two concussions to each revolution. The square or box churn gives four, and the sexangular, or Fenner, gives six. The last turns easier than any of the revolving churns. The rectangular churn, pivoted at opposite corners, also gives six concussions to each revolution, and for churning small quantities of cream it is an excellent churn. It does not seem to be adapted to churning

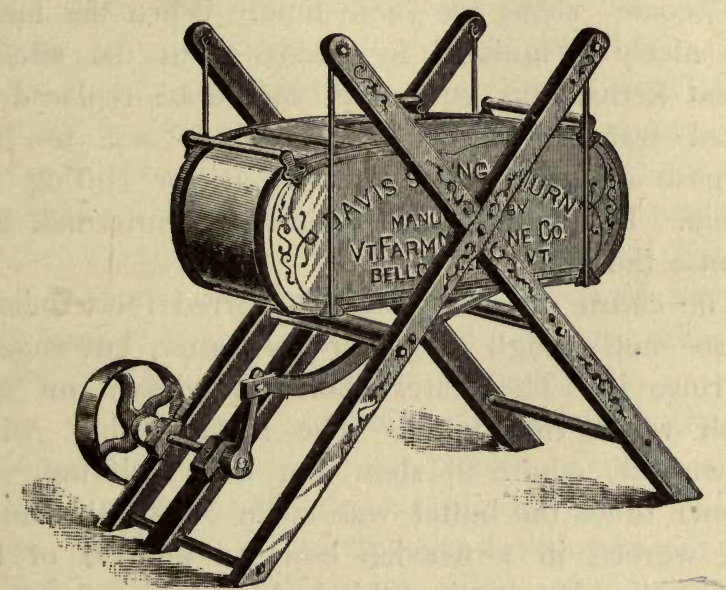

FIG. 22-THE DAVIS SWING CHURN

large quantities. The four and six sided churns are adapted to dairies of almost any size. The Davis, or swing, churn (Fig. 22) does good work, and for hand use can be used in larger dairies than most other churns. The sixty-gallon churn, capable of churning twenty to thirty gallons of cream, is perfectly adapted to hand use. In the writer's judg- 
ment, when power is used, the revolving churn is preferable. The Davis churn has one decided advantage over the revolving churn; it admits of perfect ventilation and allows the gas to escape.

The capacity or cubical contents of the churn should be more than twice the volume of cream to be churned. To secure perfect work the churn should be not more than half full at the time of churning. In properly ripened cream the butter will all "come" about the same time. When the butter has nicely granulated in grains about the size of wheat kernels the buttermilk should be replaced by salted water. This salted water is not for the purpose of salting the butter, but for cutting the casein. It also tends to remove the buttermilk and cleanse the butter.

The churn should be slightly stirred for a minute or so-not enough to gather the butter, but enough to rinse it. The water should be drawn off and fresh water substituted. The third rinsing, when drawn off, ought to show but little coloring. In former times the butter was taken out of the churn and worked in a wooden bowl to get rid of the buttermilk. By the time this had been done the grain had been so injured that the butter would not to-day sell for first class. This was not all. Standard butter of to-day contains about 83 per cent. of butter fat, 12 per cent. to 14 per cent. of pure water and salt, and the balance casein, ash, and other material. In the old process, by the time the buttermilk was worked out, most of the water was also gone, so that it took about ten pounds more of butter fat to make a hundredweight of butter than it does to- 
day. This increase in percentage of butter fat, and the poorer quality of the product, made a loss of from 12 to 15 per cent., often more, on the market product.

\section{WORKING AND SALTING}

When the butter has been washed or rinsed in the manner described it will have begun to gather. The water for this rinsing should be at a temperature of about $55^{\circ}-$ not cold enough to make the butter crumble, nor warm enough to make it salvey. The butter is then put into the worker, and, after being partially worked together by passing the worker over it two or three times, so as to spread it out, the salt is added. This should be done through a sieve, and spread evenly over the surface of the butter. Salting should be done to meet the taste or demand of the customer. It differs in different localities. As a rule, from three-fourths to one ounce to the pound is sufficient. Many customers prefer one-half ounce to the pound. Butter salted in the proportion of one-half at one ounce to the pound, one-fourth at one and one-fourth ounces, and the balance at one-half ounce, will meet the demand of average village custom. The dealer will in a short time tell the producer what the demands of his customers are. The different churnings need not be separated for the purpose of salting.

The butter should be worked just enough to work in the salt, no more. It should stand for two or three hours for the salt to get well dissolved, and then worked a little more. The mechanical butter workers in ordinary use work very rapidly, and 
there is danger of overworking. As soon as the butter begins to have a waxy appearance it is time to stop in the second working. The consistency at the time of this second working is important. The temperature of the room must be such as to make the butter just right in this respect-to wit, about $60^{\circ}$. Judgment and practice are the only guides. When the working is done the texture should be such as to admit of its being packed or printed without crumbling or breaking, and should be sufficiently plastic to pack readily into the tub and at the same time hold its shape.

The demand of the day is for pound or onehalf pound prints. Pound prints that are twice as long as wide, with a double stamp, are as a rule preferable. The stamp should have a particular design, something which will distinguish the brand from other butter. If the quality is prime there will soon be an increased demand, and the price may be increased.

Grain, flavor, color, and texture are the leading points to be attained in butter-making. Grain and texture are closely allied. Butter worked with a ladle, unless the utmost care is used, is liable to be salvey; the sliding of the ladle over the butter destroys the grain. The ladle should be used only to press the butter. Texture is indicated by general appearance and by the breaking apart of the butter. If texture and grain be all right, the butter will show a granular appearance like a piece of broken cast iron. It should not show a crumbly appearance, the result of working when too cold, or not working enough; nor a salvey appearance, the result of 
overworking or working when too warm. When broken the end should show minute particles of brine, small and clear and sparkling, diffused all through the butter.

Flavor is better tasted than described. The test is: allow a small piece to melt in the mouth and inhale the breath slowly over it and exhale through the nose. The nose will detect any improper flavor sooner than the palate. Flavor is affected in many ways. If undesirable bacteria have been allowed to get into the milk before setting, no subsequent treatment can prevent the fault showing in the flavor of the butter. Underripening gives a flat flavor. Overripening is even more injurious, both to flavor and texture; the butter has a bitter flavor and quickly becomes rancid.

Color must be made to suit the market. It is a matter of taste. The general rule is a medium color, dark enough so that no traces of a lardy appearance remain. Overripening is often a cause of mottled butter.

One motto should be conspicuous in dairy practice: "Like causes produce similar results." Methods and practices that produce prime butter at one time will do so at every other time. If there be a difference in the results there must have been a change in the causes. When a prime butter has been made the same methods should be followed to secure favorable results again.

Good sales from a dairy depend upon the dairy's reputation. This is made by the uniform quality of the products. Modern methods and appliances permit almost perfect uniformity in practice. Where this is attained, uniform results must follow. 


\section{CHAPTER XVII}

\section{MARKETING DAIRY BUTTER}

THERE are many ways of marketing dairy butter. Local conditions must be considered in determining the method by which the products of the dairy are to be put upon the market. In former times it was the practice to pack the produce of the season in tubs or firkins and sell in the fall. This method is now nearly obsolete. The market demands a fresh product. If a good price is to be obtained for it, the product must be prime.

Prints are rapidly coming into favor for both city and village trade. Local markets are preferable where possible. It is generally possible to obtain a market near home for butter superior to one's rivals. Some local dealer should handle the entire product, which should be delivered to him at regular intervals. The quality and salting must be kept the same at all time. A printed sign should supplied for the use of the dealer-as, "Glen Farm Butter for Sale Here." When customers find that they can rely upon a brand every time they will call for it. Not only that, they will mention the matter to their neighbors, and the dealer will call for more and more. If the brand be placed on any butter that is a little off, the trade will be quickly injured. The customer may stand it once, but the second time you have lost him. No one can afford to allow a single print not strictly prime to go to the market with 
his stamp on it. If he finds that it has occurred he should see that the dealer replaces the inferior butter at once, without expense to dealer or purchaser. Custom once lost is hard to get back. If a churning is not prime, it should be put in a tub and sold in the general market.

If the dairyman lives near a town of sufficient size it will pay him to make contracts for custom delivery the year round at given prices-one price from May Ist to October Ist, and another price from October ist to May ist. As a rule, a fixed price for the year is not satisfactory. When butter is low in the summer, customers give all sorts of excuses for not wanting as much as usual. When it is high in the winter they will want more than the usual weekly allowance. It is a convenient way to help out their neighbors when market butter is scarce and high. It is hard for them to pay in summer several cents more than they would have to pay in the markets and their cooking-butter is likely to come from the stores.

\section{A NAME FOR THE FARM AND A BRAND FOR THE PRODUCT}

Each farm should have a reputation for prime products. Glen Farm Dairy, the name of the writer's farm, is well-known within a radius of one hundred miles. The name and reputation of a farm is a part of the owner's stock in trade. This is especially true in the dairy business. Merridale Farms, of New York, is a brand which brings from thirty-five cents to fifty cents a pound for its butter. The same butter bearing the brand of an unknown 
dairy would not be worth two-thirds the price "Merridale" commands. The brand should be uniform, and, whether initials or an emblem, it should be used only on prime butter. It should also mean that the butter will be replaced if by accident an inferior grade is stamped with it-in short, that the quality is warranted. A little printer's ink, judiciously used, calling the attention of the public to the dairy and its products, is money well invested. It requires effort to make a reputation, and continued vigilance and effort to maintain it.

\section{APPEARANCES ON THE DAIRY FARM}

The external surroundings of the dairy farm have much to do with its reputation. Well-painted buildings, clean whitewashed stables, clean-looking cows, a tidy dairy, generally attractive appearance of the house-all form important parts of the make-up of the dairy farm. They are loud-speaking advertisements assisting in the sale of the products at an attractive price. Every opportunity should be taken advantage of to show possible customers and their friends over the buildings and premises. Confidence in one's self and pride in the business will soon draw customers, instead of forcing the dairyman to seek them. It is not at all difficult in this way to secure five cents a pound above the average local markets in a short time.

In delivering to special customers, one dollar a hundred pounds should be added for the cost of delivering and collecting, which last should be done as often as once a month. In making weekly deliveries to individual customers this added cost must be con- 
sidered. Print butter will not retain its flavor for more than two or three weeks, and should be consumed within that time. It should, therefore, not be allowed to accumulate at the dealer's. When any left over is more than two weeks old it should be taken back, packed, and sold as tub butter. Deliveries to local dealers should always be placed where there are no foul odors. Fish, kerosene, tobacco, and the like, if stored near it, will taint the butter. The average dealer is not careful enough about these matters. 


\section{CHAPTER XVIII}

\section{THE DAIRY BARN}

THERE is in agriculture, as in all other kinds of business, an indispensable adjunct. That requisite is a man. That wanting, all other conditions, no matter how favorable, will bring no success. The man must be one who follows his business because he likes it. If dollars and cents alone be the motive in making the selection, it is not likely to be many years before he decides that some other business is better adapted to his tastes and purposes. Assuming that the first motive has induced the man to select dairying as his business, and that he has entered it with the determination to win success for himself and happiness for his family, his first thought will be to surround himself with the conditions which make success and happiness possible.

One of the first requisites for succesful dairying is a barn adapted to the purpose. Three elements deserve prime consideration: light, warmth, and ventilation. The idea of ventilating by a long airshaft, such as is often found in barns, should be abandoned. The writer's barn, which has been largely patterned after, has been used for ten years, and if he were to build another no material changes would be made in its plan. The first problem was to have ventilation but to eliminate draft, no matter from what direction the wind 
blew. The next proposition was to have ventilation readily controllable. To accomplish these ends all parts of the stable had to be as nearly air-tight as possible, except at the points from which ventilation was to be secured.

The barn is of the type known as basement-i.e., the cow stable extending under the entire structure. The first, or basement, story is eight feet in the clear. There are windows of ample size on every side, so that the stable is better lighted than the average living-room. It is sided up with surfaced lumber, to secure an even surface for the first covering. The surfaced side is placed inside for whitewash. This course of boards is nailed to a strip on the beam and sill, one inch inside of the outer edge of the timbers, so that the next sheeting comes flush with the outside. Good building paper is put on the outside, and a second course of boards covers the whole, carefully breaking the joints. The outside course of boards is battened with freshly painted strips, painted inside, put on while the paint was still soft. This makes the joints air-tight all the way around, and prevents the entrance of air except at the ventilator made for the purpose.

\section{FLOOR}

The outside measurement of the width of the barn is thirty-eight feet. This is the best width for a stock barn. It allows about seven feet for a feedingalley next the side of the barn, the cows facing the outward. It also allows about two feet for a manger, four feet six inches for platform for cow, in 
addition to the room taken for the stanchion, fourteen to sixteen inches for drop and eight feet for driveway between the drops, with similar room on the opposite side for a double row of cows. Mangers of box form that come to a level with the cows' heads should be avoided. A box that comes to the nose of the cow as she stands catches her breath and makes her breathe the same air over and over again, contaminates her food, and renders it unpalatable, so that she will not eat it. When cows face each other, with a narrow feeding-alley between, and a high manger before each cow, the conditions are highly unsanitary. The cow breathes not only her own exhalation, but those of the others as well; their heads are in the warmer atmosphere and the bodies in the cooler-conditions regarded as injurious to health.

In the barn being described the feeding-alley floors are ten inches above the level of the cow platform and feeding-places. A slope board, or plank, extends from the edge of the floor to the bottom of the feeding-place. The bottom of this slope board should not be over twenty-three inches from the front of the stanchion. More than this makes a cow strain to reach the feed at the front side of the feeding-place, and in doing so she pushes her bedding from under her into the gutter behind. This space, ten inches deep and twenty-three inches wide, is all that is needed. From four to four feet six inches should be allowed from stanchion to gutter for standing room. Few cows are less than four feet long in body and few more than four feet six inches. From the edge of the cow platform to 
the bottom of the drop, or gutter, should be eight inches. The platform should slope slightly toward the gutter. One-half an inch to the foot is plenty. Too much is believed to produce injurious effects. The level of the driveway should be two inches lower than the cow platforms. Drops should be from fourteen to sixteen inches wide and watertight. Driveways should be eight feet wide, no more, no less. Wider is inconvenient for shoveling the manure on manure boat or wagon, narrower will make the whiffletrees interfere with the cows when driving through.

In the past few years there has been so great an advance in the price of lumber that the cost of construction of stable floors has become a considerable item. Wood floors must be occasionally replaced. Cement floors seem to be the only solution of the question. Of late years many of these have. been put in and are in successful use. It seems advisable to arrange for wood platforms under the cows. Oak, red beech, or some other durable wood can be imbedded in the concrete as stringers upon which to spike the platforms. The surface of the concrete must be roughened to prevent slipping. When once put in, these floors are permanent, and in the end are cheap. One great advantage is the saving of all liquid manure, an important item.

\section{STANCHIONS}

The stanchion should be three feet four inches to three feet six inches from center to center; three feet is too narrow and crowds the cows. This is a place 
where inches count. A rigid stanchion should not be used at all. The swing stanchion, fastened at top and bottom with a few links of chain, so as to allow a play of two inches or thereabouts, back and front, will be found satisfactory. The swing stanchion turning upon a pivot, stationary at top and bottom, does good work, but is not as satisfactory as the former. This is a point upon which dairymen differ in opinion, and each is left to his choice. The use of the swing stanchion lightens the task of keeping cows clean better than any other method.

Sloping partitions reaching within a foot of the drop should separate the cows. This prevents injuries to udders and teats by cows stepping on each other. The space between the end of the partition and the drop leaves room for the milking stool. In front of the cows a similar partition should be placed for each alternate cow. This permits each cow's feed to be placed where the next cow cannot steal it, and each may eat her own food unmolested. It allows a watering device to be placed between two cows, so as to be available to each. A cast iron salt box should be bolted to each side of the manger partitions so that each cow may have her individual salt dish.

\section{VENTILATION}

Nothing in the construction of the barn is more important, and at the same time more difficult, to secure than ventilation. Much has been written upon this subject; a great deal of what has been said has been based upon erroneous ideas of aerial circulation. All successful ventilation must be based 
upon the fact that warm air rises and co!d air falls. The ventilation in the barn described was arranged with this law as its basis, and has worked satisfactorialy. The construction is as follows:

The driveway in the second story crosses the barn at right angles with the cow stables, and is entered by a short bridge and grade at the side of the barn. On each side of this driveway, about three feet above it, separating it from the bays in either end of the barn, are the "breast girts." Next to the side of the barn, under the girts, a space is partitioned off, allowing an opening about three feet square from the side of the driveway to the stable beneath. There are three of these openings. In the fourth corner is the stairway, which makes the fourth ventilator. Slides are placed before the three openings, closing them wholly or partly, as needed. The stairway is closed by a trap door, operated by pulley and weights. The cold air being heavier than the surrounding atmosphere, as it comes through the opening, drops to the floor. As it is breathed by the cattle and warmed by their bodies, it courses toward the center of the barn and toward the ceiling, thence to the openings and out. At each of these openings will be found the two currents, the cold air going in and the warm coming out. These currents have been proved experimentally with smoke. The moisture formed by the breathing in the stables below often condenses in cold weather in the barn above, and forms considerable quantities of ice; another evidence of the circulation. At the "peak" of the barn is a ventilator $8 \times 6 \times 5$ feet. Its sides are composed of slats, which admit the 
passage of air, but keep out the storm. The fresh air enters at the windward; the warm air escapes to leeward.

In cold weather this system works perfectly; in warm, foggy weather, the circulation is sluggish and the ventilation not active enough. Then a slide door put in at the end of the driveway may be partly opened. This makes the circulation sufficient to ventilate the barn perfectly at all times. Another opening under breast girts in the center of the barn is made for the purpose of throwing down bedding material, but this is never used for ventilating purposes. The other places are also used as hay chutes. In dropping from these to the floor of the basement, the major part of the dirt is shaken out.

\section{FEED ROOM}

In one corner of the barn is a room for storing feed. It is divided into bins, one of which is used for mixing. From it there is a spout leading to a box in the stable below. On the opposite side of the barn a space is partitioned off for another feed bin for use on that side.

\section{HOSPITAL STALLS}

Every barn should have two or more hospital stalls. In a herd of twenty-five cows there should not be less than three, each at least $9 \times 12$ feet. They are for use of cows expected to come fresh. When not needed for these purposes, they may be 
used as stable room for the bull. To be used for this purpose the partitions and gates should be made strong.

\section{THE MILK ROOM}

The dairy or milk room, above all places on the farm, requires pure air and perfect ventilation. Pure water and perfect cleanliness are also absolutely essential. When the location of the dwelling house is available a part of the cellar can be used. The space from the ground to the top of the cellar may be used, and this must be enough to admit plenty of air and light. Light should be admitted, where possible, from the east, south, and north. The grade of the ground must be such that the cellar can be entered by a level passageway, which should be from the east or north side, when possible. If the slope does not admit of a level passageway, the cellar is not available as a first-class dairy room. It is not possible under such conditions to secure the ventilation required in the dairy. Air in a cellar is cooler and heavier than the outside atmosphere. Unless there is an egress as low as the bottom of the cellar, the air remains stationary and a defective dairy room is the result. The dairy cellar should not be less than seven feet between joists; higher where possible. Windows should be hung on hinges, so as to enable their raising and opening upward. The window openings in summer should be covered with fine wire screens. They should be closed after 8 A.M. to keep out moist air, and be opened again at night to admit the dry night air. 
This may sound paradoxical to persons who have never given thought to the subject. Night air is dryer than that of midday. During the day the air is absorbing moisture. At night, as it cools, the moisture is precipitated. Therefore the night is dryer by just this difference. It is also cooler and is for that reason better for the dairy room than that of the day.

Stone or cement floors should always be used in the milk room. Good drainage, so that the floors can be rinsed and cleaned frequently, should be provided. The drains, constructed of good tiling to admit of thorough cleansing, should be cleaned, at stated intervals, with concentrated lye. If a separate building be used for a milk room, and be constructed of wood, the outer and inner lining should be separated by studding at least five inches wide; six is better. This provides an air chamber to act as non-conductor of heat. If this space be filled with sawdust it will aid in keeping the room cool. The building should be shaded by trees. In four or five years, Carolina poplars will grow large enough for the purpose. Maples planted at the same time, in a little longer time, will furnish a better shade. A good-sized ventilator should be built in the top to permit the warm air to escape from the space under the roof. When the milk room is in the cellar, it should be separated from the root cellar by an air-tight partition, and the doors between hung with springs to keep them closed. If an outdoor building is used a refrigerator will be necessary to store the prints.

A good stove is an indispensible adjunct to the 
dairy room. Building paper will aid in keeping the room cool in summer and warm in winter. The outside should be double-boarded and battened with building paper between. The temperature must never be allowed to get to the freezing point. Plenty of light is essential, but with no more of the sun's direct rays than can be avoided. A steep roof is better than a flat one. The door should open to the east or north, and the building stand with the long way north and south. This gives less exposure to the sun's rays. 


\section{CHAPTER XIX}

\section{THE SILO AND SILAGE}

For several years past the silo and silage have become matters of great interest to the eastern stock raiser. There is no one branch of the business that strikes deeper into the pocketbook than that of feed. Important as is the subject of breeds and breeding, it can never overshadow that of feeds and feeding. Breed without feed would be of no avail to the stock raiser. Does silage pay? is the first problem to be solved by the man who has not already informed himself on the subject. If it does not, or there be some food that is more readily available and can be used with greater profit, the how of raising silage and how to save and feed it are of little consequence.

In the early days of the silo in this country, $\mathrm{Mr}$. Devereaux, of Deposit, N. Y., determined to know what it was worth to him. He had followed the tanning business until the hemlock bark in this country had been exhausted, and then turned to stock raising. He constructed a silo and filled it with a good crop of corn, raised and stored according to approved methods. He went to Buffalo and purchased thirty-six steers. These he divided into two lots of eighteen each, weighed them, and began feeding. To one lot he gave hay, grain, and a half bushel of turnips daily; to the other he fed turnips, silage, and 
the same amount of grain. $\mathrm{He}$ soon found that the steers eating silage did not need the turnips, and discontinued their use as to that lot. The steers were again carefully weighed at the close of the test, which lasted thirty days. The silage-fed steers gained seventy-seven and a quarter pounds a head; the hay-fed gained a little over thirty-nine pounds, making a difference of thirty-eight pounds. Mr. Devereaux did not report the amount of silage fed to each, but it probably did not exceed fifty pounds daily. The added beef was worth five cents a pound, or $\$ 1.90$ a head advantage in favor of the silage-fed steers. The total cost of silage per capita was not over \$I.oo.

All over the country to-day farmers are using silage as a prominent part of the dairy feed. The general opinion among observing feeders is that the gain in feeding for milk is fully as great as when feeding for beef. The cost of raising silage will not average over $\$ 1.25$ a ton when economically and properly conducted. Its value as a food cannot be based upon the analysis as reported by the chemist. A great part of its value consists in its ready assimilation. It is succulent and aids in the digestion of the hay, grain, and other foods forming the balance of the dairy ration. Its value as an auxiliary to the digestion of other foods is fully as great as its direct food qualities, as shown by chemical analysis.

The acidulation which occurs in the curing process aids digestion. Until lately condensed milk factories have refused milk from silage-fed cows. Some factories are now successfully using milk for condensing purposes where silage of good quality 
has been fed in moderate quantity. Undoubtedly in the near future good silage will come into general use for this purpose. It should be fed under prescribed methods and not to exceed thirty-five pounds a day after milking. For the production of butter, if fed at the above rate and after milking, silage is certainly an improvement. Better butter can be made with its use than without it. I have found that not only was better butter the result of its use, but also the cost was greatly reduced.

The flow of a silage-fed cow, with clover hay and grain to make a balanced ration, is very little behind that of a cow on grass in May and June. When turned into grass in the middle of May, after the pastures have a good start, the flow was increased but very little. The cow that comes fresh late in the fall or early winter, fed on silage, and enough other food to make a balanced ration, will produce 25 per cent. more milk and butter than the cow coming fresh in the spring with the same care and rations, for reasons given hereafter. In producing this result, silage is in favor.

An important item in the raising of silage is economy in land. Good silage ought to yield at the rate of from ten to twelve tons to the acre. This at a relative food value of two and one-half tons to the ton of hay is equivalent to about five tons of hay per acre, or a saving of nearly one-half the land, in taxes, interest, repairs, etc. Yields of from fifteen to twenty tons of silage to the acre are not uncommon. Land which will yield two tons of hay to the acre is likely to exceed twelve tons of silage. 
The cost per acre of producing silage is about as follows :

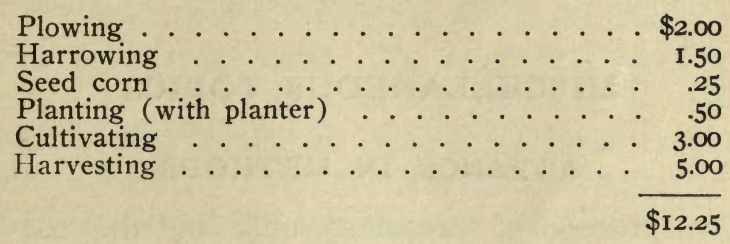

This will average about $\$ 1.00$ a ton, interest and taxes not included. The foregoing allowances are liberal. The writer has raised silage, keeping strict account, when it cost but eighty-five cents a ton in the silo. One dollar a ton, however, is the safer estimate.

When properly grown and harvested, silage is one of the most economical feeds grown on the dairy farm. It makes one acre do the work of more than two, and balances the competition between the high-priced lands of the East and the cheap but fertile lands of the West. In its production, land, money, and labor are greatly economized. The most exhaustive work on this topic is "Soiling Crops and the Silo," by Prof. Thomas Shaw, of University of Minnesota. Another practical treatise is "Silos, Ensilage and Silage," by Dr. Manly Miles. 


\section{MISCELLANEOUS TOPICS}

\section{ADVANCE IN METHODS}

The process of creaming milk by the use of shallow pans, as followed thirty years ago, lost fully to per cent. of the cream. Fully io per cent. more was lost by the old dash churn, and went into the swill barrel. Butter made by old-fashioned methods would to-day bring at least Io per cent. less than that made by modern processes. It takes the same labor to milk a cow to-day that it did one hundred years ago, but from that point on the results of labor-saving appliances are apparent. The labor required to set and skim the milk in small pans, wash and set the pans for the next milking, ripen the cream, churn it in the old dash churn, work the butter by hand, is twice that required to produce better results by modern methods.

\section{WEEDING OUT THE DAIRY}

One of the most unpleasant tasks of the stock breeder is picking out the unprofitable cows and disposing of them. The scales and the Babcock test are an unfailing measure of merit and should be rigidly applied. Great expectations as to some well-bred heifer are often disappointed. Any cow that at five years of age does not prove at the pail her right to stay in the dairy should be sold for beef 
for what she will bring. No matter if her dam was of exceptional value, and the sire of great worth, if she has not the individual merit she should give place to a better cow. She must first have a fair chance to prove that her performance is not the result of bad feeding or some other cause capable of being remedied. The fault must be proved to be hers and not that of her. environment. By always taking care to select sires of the best quality, and to get calves from the best mothers, this method will in a few years secure a herd in which individual preferences will be few.

\section{DEHORNING}

Horns are the weapons of offense and defense by which in the wild state cattle protected themselves. As a domestic animal, the cow has no further use for them. The condition of fright and fear common among herds where horns are worn materially affects the average flow of milk. Careful observation has shown that the dehorned cow is not affected by the operation for more than two or three days, and then not to a great extent. The time to dehorn a heifer is while she is a calf less than a week old. As soon as the knob begins to appear, the hair is cut close over it about the size of a nickel. Caustic potash, in the stick form, is then moistened and rubbed on until the blood shows through the skin. After a few minutes the operation is repeated and the work is done. Allowing the potash to get soft and then pasting it on is unnecessary cruelty. 


\section{WASTE IN MILKING}

The hired man is not likely to stop to compute the loss incurred by leaving a half-pint in the udder at each milking. The last half-pint is three times as rich in butter fat as the average of the whole milking. Figuring on this basis, there would be a loss equivalent to 900 pounds of milk in 300 days; at one dollar per hundred, this means a loss of $\$ 9$ a year per cow. In a herd of fifteen cows, this would mean a loss of $\$ 135$-nearly the wages of the man. But the loss of milk and butter fat is not the only one. Under such treatment the flow of the cow will decrease. The man who has charge of the dairy should see to it that every milker milks his cows clean. It is from these apparently small matters that the gain or loss in a dairy comes.

\section{FEEDING THE DAIRY COW}

Enough has been said on cow feeding to give a general idea of this subject. The cow cannot be expected to furnish all the brains needed to run this branch of the dairy. No more hay or straw should be fed than the cow will eat at a meal. When she stops eating, her manger must be cleaned out and allowed to remain clean until the next time for feeding. She will soon adapt herself to this order of things, and when done eating will lie down. She will not get up every time the attendant comes into the stable as if she expected another feeding. She is a creature of habit. Upon the attendant depends the regularity of those habits. The more regular they are the better work she will do in the dairy. 


\section{KICKING COWS}

There is no excuse for having a kicking cow in the herd. The kicking cow is invariably made so by her attendant. If a cow is handled before she comes in, so as to become familiar with her attendant, and has been kindly treated, there will be no trouble. If a cow or heifer gets the habit of kicking, or seems in the way of forming the habit, one of the following remedies is suggested: A strap or rope buckled tightly around the body just in front of the udder and the hips. This usually effects a cure. Another method which has been successfully tried is to use a stick about eighteen or twenty inches long, crooked and hollowed so as to fit the leg at the hock joint. This is fastened by a strap at the top, another just above the hock, and a third several inches below it, the straps being made long enough to go around the leg and some to spare, and with the tongue holes close together. The middle strap is buckled first and then the upper and then the lower one. After this is put on the cow will try to kick, but she will soon discover its impossibility. After a few trials there will be little difficulty, and it usually is but a short time before the cow will stand without the contrivance. In using this appliance, the dairyman must be patient with the cow. She must be made to know that she is not to be hurt, except as she hurts herself. The stool described elsewhere should be used, and the pail protected by placing the knee against the cow's leg. When she tries to kick she cannot get her leg forward nor into the pail. 
When kicking becomes chronic, so that the cow will yield to neither of the above treatments, she may as well be considered as a hard case and disposed of.

\section{WARM WATER FOR COWS}

Having water before each cow in the stable is desirable. In most places it is practicable. The gain in milk will pay heavy interest on the money invested in the cost of the appliance. When this is not practicable, it will pay in a large dairy to have a small boiler from which steam pipes pass into the trough to raise the temperature.

In the celebrated dairy districts in the town of Bovina, Delaware County, N. Y., a number of these appliances are used. The dairymen of that section find that warming the drinking water of the cows materially increases the flow of milk. A useful appliance where water is kept always before the cows is a dish covered by a board that drops over the bucket. The cow raises it when she desires to drink. When the water is at the proper temperature the cows drink many times a day and but a small quantity at a time. No cow can both digest her food to warm ice water and at the same time convert it into milk and butter fat.

\section{COST OF PRODUCING MILK}

If one thousand farmers were asked what it costs to produce a hundredweight of milk or a pound of butter, it is doubtful if twenty could give an intelligent reply. The cost of butter depends upon so many conditions that each case must needs be answered by itself. In a well-kept herd of specially 
bred animals, adapted to the production of milk and butter, under favorable conditions, the cost is about as follows:

\section{FEED COST PER ANNUM PER COW}

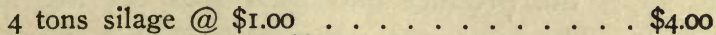

I,500 pounds hay $@ \$ 8.00$........ 6.00

I ton ground feed . . . . . . . . . 20.00

Pasturage ............. . . 6.00

I,200 pounds straw ......... 3.00

$\$ 39.00$

Labor, cost, including butter making . . . . . I0.00

Total expense ........ $\overline{\$ 49.00}$

Under the conditions enumerated, a per capita product of 6,000 pounds of milk, or 300 pounds of butter, could reasonly be expected. This would make the cost of producing milk 81.6 cents a hundredweight; butter, I6 I-3 cents a pound. If the cow be credited with skim-milk at ro cents per 100 pounds, it would reduce the cost of butter about 2 cents a pound.

The cost in the average dairy at the present time, throughout the country, is about as follows:

Hay, 2 tons ........... \$16.00

Pasturage ............ . . 6.00

Grain, 600 pounds ......... 6.00

Labor cost ............... 10.00

Total ............. . $\$ 38.00$

Average milk production .....3.500 pounds

Average butter production .... I50 pounds

Cost per hundredweight milk . . . . . \$1.08

Cost per pound butter .......... . . 24

Crediting the skim-milk reduces butter cost to about 22 cents.

There is one important item in this calculation 
of which the feeder must not lose sight. The farmer has sold his hay to his cow at $\$ 8.00$ a ton, his pasturage at $\$ 6.00$, his grain at $\$ 20.00$ a ton. Into this hay and grain has entered his labor precisely the same as if the product had been sold off the farm for cash. He must not, therefore, charge as labor account against the cow any of the time expended in producing his feeds. Incidental expenses, such as taxes, interest account, repairs, etc., should be taken care of in the by-products-calves sold, manure saved, etc. The manure alone is worth from $\$ 12$ to $\$ 15$ a year per cow. It is the fault of the owner if this fertilizer value is not saved.

\section{SKIM_MILK}

The value of skimmed milk depends largely upon the uses to which it is put. If there are facilities for producing steam to cut hay and straw and grind feed, the skimmed milk can be sprayed into the feed. When so fed, it takes the place of an amount of grain which makes its feed value about 25 cents a hundredweight. This statement is made on the authority of John T. McDonald, of New York, one of the most successful dairymen in that State. $\mathrm{He}$ conducts his dairy upon business principles and is a close and careful observer. For feeding calves and hogs for the market, skimmed milk is cheap at Io cents a hundredweight.

The following is a comparison of the feed values of buckwheat middlings with skimmed milk:

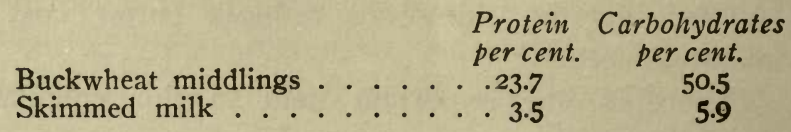




\section{CHAPTER XXI}

\section{NECESSARY APPLIANCES}

\section{BUTTER WORKER}

ONE of the important appliances of the dairy is a butter worker. Its capacity should be greater than thc estimated use. There are many varieties, roller,

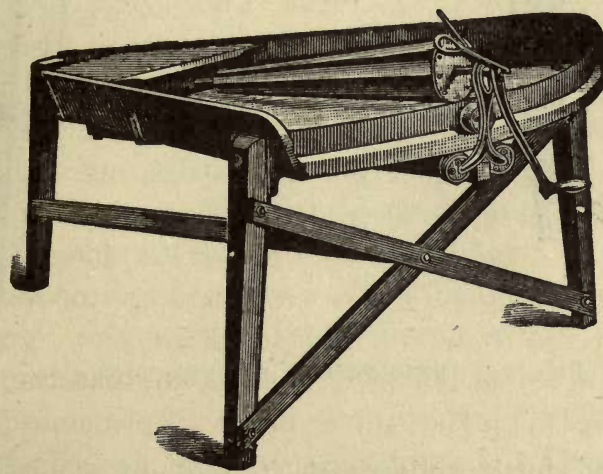

FIG. 23-THE SKINNER BUTTER WORKER

corrugated, lever, etc. The best is the corrugated roller worker that passes back and forth over the butter. The corrugations should be rounded instead of angular. Rounded corrugations squeeze the butter, forcing out the brine, and work more by press- 
ing than by cutting and sliding. (Fig. 23.) One machine reverses action by slipping a cog-wheel. It rolls the butter after working it. (Fig. 24.) The writer has used one of these machines for the last ten years, and considers it the best he has ever used. The roller is stationary, the table sliding

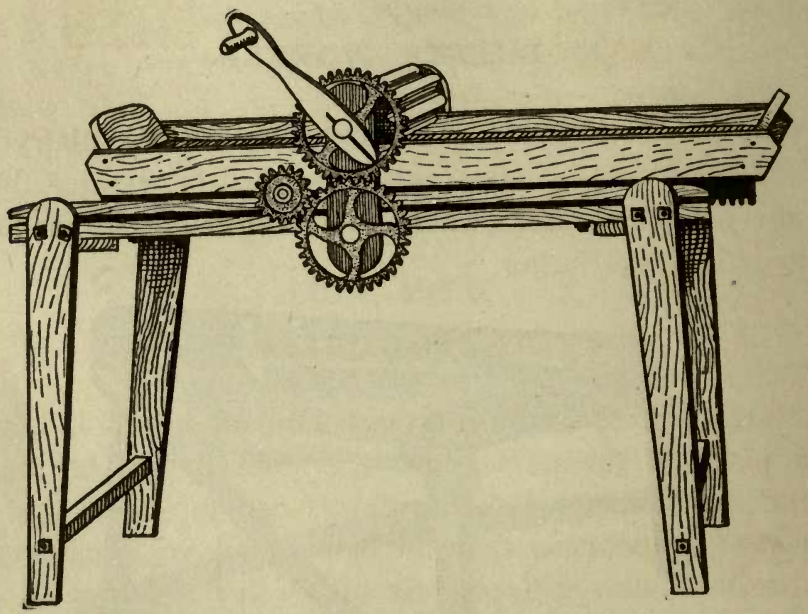

FIG. 24-REVERSIBLE BUTTER WORKER

back and forth underneath it, without changing the direction or reversing the handle. Any form of worker that slides or slips over the butter greatly injures the grain. The hand should not be allowed to touch the butter at any time. The ladle (Fig. 25) should never slide over the butter to smooth it for the reason mentioned. A butter bowl is not needed. A straight-edged paddle (Fig. 


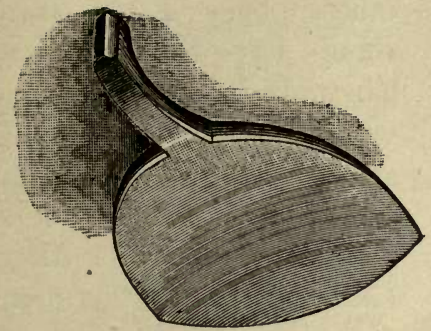

FIG. 25 -LADLE

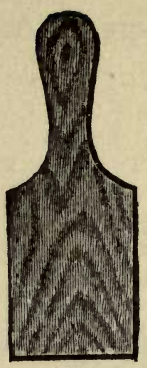

FIG. 26

STRAIGHT PADDLE

26) is the best form of wood instrument with which to handle the butter.

\section{THERMOMETER}

Of all the instruments and appliances which have a place in the dairy, few are more important than the thermometer. Nothing is more unreliable as a test of temperature than the hand or finger. Temperature must be registered to a nicety in the dairy.

A large proportion of the thermometers for sale in the markets are faulty. A dozen taken at a time and compared with a tested thermometer may show three-fourths of them to be incorrect. Those costing one, two, or even three dollars may be as much out of the way as the cheaper ones. Thermometers should always be purchased from some reliable dealer who can vouch for their accuracy. In most counties in the State there are weather stations supplied by the government with accurate thermometers with which purchased thermometers may be tested. 
A correct one may be kept as a standard to test

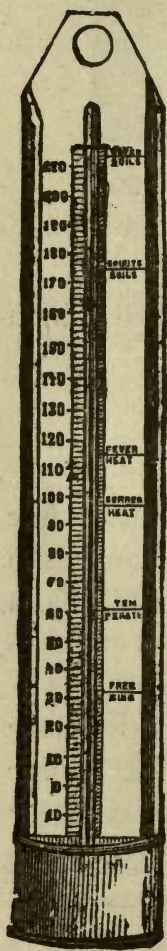

FIG. 27

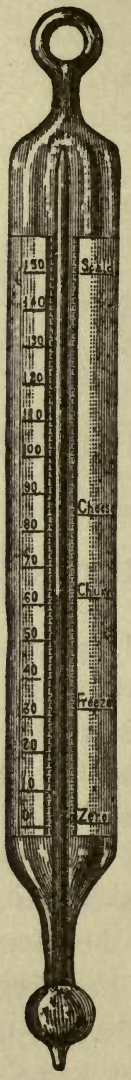

FIG. 28

FIG, 27-DAIRY THERMOMETER

FIG. 28-FLOATING GLASS

THERMOMETER

others by. Each farm should have three or four. They are inexpensive. One will be needed in the cow stable, one in the living rooms, one out of doors, and one or two in the dairy. Leading styles of thermometers are seen in Figs. 27 and 28 .

It is not sufficient merely to compare a thermometer with one known to be correct. The test should be made as follows: Place the thermometer in ice water. Gradually raise the temperature to $100^{\circ}$. Note carefully as they pass from $40^{\circ}$ to $70^{\circ}$ to see if they are all alike; if not, note the variation and mark it on the thermometer so that it cannot be forgotten. In raising cream by the gravity process the temperature must be below $50^{\circ}$. It is best, if possible, to keep it under $45^{\circ}$. This temperature of the barn, in cold weather, should be maintained as near $45^{\circ}$ as possible. 


\section{THE ICE HOUSE}

The ice house is another important adjunct to the dairy. The manner of erecting ice houses is so generally understood that little need be said about it. The bottom should be constructed of poles and straw, to permit drainage. Studding not less than $2 \times$ io inches should separate the lining boards from the outside sheeting. This space should be filled with dry tan bark or sawdust. Ice houses made in this way will need but a few inches of sawdust around the ice. The ice house should be banked with sawdust and the banking covered with boards. It is important that this banking be kept dry, for dry sawdust is a more perfect non-conductor than wet.

Before taking the ice to the dairy room, every. particle of sawdust must be washed off. Moist sawdust produces an odor injurious to the milk and is likely to clog drains. Ice should never be allowed to come in contact with milk, cream, or butter. If it touches either the effect will be nearly the same as that of boiling water. It will make the butter white and streaked. The cooling effect of the ice must be conveyed indirectly. The water in which the ice is put should be changed every two or three days.

\section{CARE OF DAIRY TOOLS}

Carelessness with tools will invariably work ruin in the dairy accounts. Cleanliness is imperative in the dairy. There is nothing more susceptible to odors and flavors from surrounding objects than milk, 
cream, and butter. Nothing must be permitted in the dairy that is not sweet and clean. Tinware should have all seams filled smooth with solder to prevent the accumulation of dirt. Utensils should not be allowed to become rusted; a rusted surface is difficult to keep clean.

Tin vessels should be carefully cleansed with warm water, and then scalded. Warm water will melt the butter fat. The hot water destroys all bacteria. Covers must be removed from cream pails, and all other receptacles, when not in use. Coats, overalls, vests, etc., worn about the barn should not be worn in the dairy. Whitewash, water, and paint should be freely used in the dairy room. The churn should be frequently inspected to see that no dirt or grease is accumulating in it. The scrubbing brush should be freely used. The nose will be likely to discover anything wrong with the churn, but the eyes must assist. The author once discovered that his churn was not making good butter. After a long hunt it was found that the attendant had not kept the vent hole in the cover clean. The butter worker needs to be carefully looked after. It should be taken apart frequently and every part cleansed. The top of the table can be easily scrubbed and cleansed, but the whole machine needs looking after. In cleansing dairy utensils, scalding water should never be used. Boiling water will cook the milk or cream and cause it to adhere tenaciously to the sides and bottom of the vessel. On tin dishes it will have to wear off before it can be gotten rid of. Scalding water is to be used only after the vessel has been cleansed; prior to that only warm 
water is to be applied. When drying dairy utensils care should be taken to place them in such a position as to allow free circulation of the air. Wooden dishes should not be exposed to the sun enough to cause them to check. They should be kept free from contact with sour milk or cream.

\section{MILKING STOOLS}

Plenty of good milking-stools are essential in the stable. If the attendant is not comfortable while milking, the cow will find it out from the irritable-

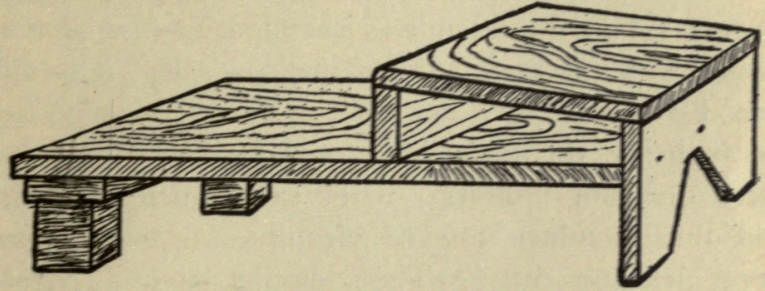

FIG. 29-PUK'S MILKING-STOOL

ness and ill-temper likely to be displayed. There are many forms of stools of merit. The ones used in the author's stables are made as follows, as shown in Fig. 29: The entire length is eighteen inches; seat, eight inches long; front, seven inches high; rear, eleven inches. This makes the pail board pitch slightly forward. The front of the seat over the pail board is three inches and the rear two and onehalf inches. This makes the seat level. Stools should be made of seasoned hardwood, although pine or basswood one and one-quarter inches thick will do. 
A strip three inches wide and one or more inches thick should be firmly nailed across the front end of the stool to hold the legs. The piece under the front of the seat should not be less than two inches thick, as it strengthens the stool and gives it firmness. A piece should be nailed across the front of the milking board to prevent the pail slipping off. The whole should be made of planed lumber and painted. It is then much easier to keep it clean, and it becomes a creditable adjunct to a well-kept stable.

A few extra stools should be provided with the pail board an inch or two lower than the regular stools. These are useful in milking short-legged cows. When the attendant is seated on one of these stools, with his knee against the cow's leg, it is difficult for her to get her foot into the pail. These stools bring the pail close to the udder in a place convenient for milking. They save much spattering and thus conduce toward cleanliness. Stools must never become dirty. They should have a regular place in the stable, and the milkers must be made to keep them there. If a stool is found to be giving out, it should be promptly repaired or a new one put in its place. Milkers should never be allowed to break up stools by careless use.

\section{THE BABCOCK TEST}

The Babcock test is an instrument that no dairyman can afford to be without. In former times the only way by which a farmer could ascertain the value of an individual cow was to raise and churn her cream separately. This was inconvenient and burdensome. The average farmer preferred to take 


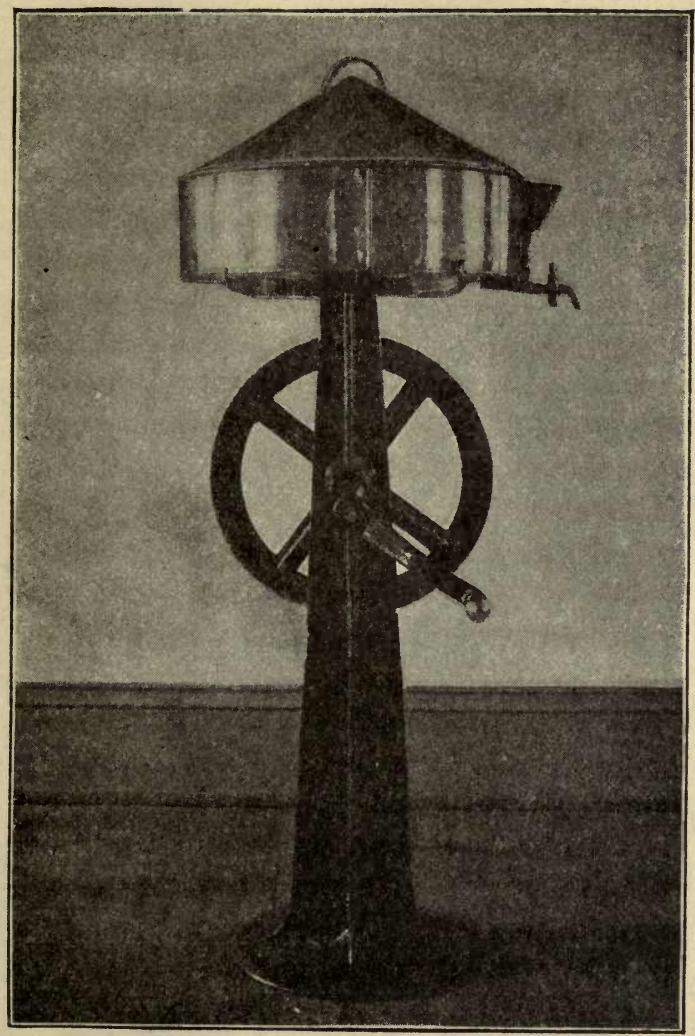

FIG. 30-THE ORIGINAL BABCOCK MILK TEST 
his chances rather than take the trouble to make this test. It was formerly supposed that a cow's value was measured by the amount of cream she produced. The Babcock test reveals the fact that cream from different cows differs as widely in the amount of butter fat that it contains as does the milk. After the advent of the Babcock test it was not uncommon to find that what had been supposed to be the best butter producer in the herd was in reality an unprofitable cow, and the little cow, supposed to be of little value, was producing more butter fat than the others.

There is really no other safe guide in learning the value of a dairy cow than the Babcock test. The matter of breeding merely increases the chances of getting a profitable cow. Poor animals will be found in the best herds. They may be rare, but the owner nevertheless needs a ready means of ascertaining their value. It is equally important that the dairyman should have a means of testing the results of his own efforts. He needs must know whether the butter fat delivered by the cow into the milk pail is conserved by him or lost in the process of butter manufacture. He must be able to trace the waste if he finds it. The Babcock test is the un- failing solver of all these questions. The original Babcock milk tester is seen in Fig. 30.

The Babcock test showed the author that his oldfashioned dash churn was wasting one pound of butter in ten. With it, his father and grandfather, without suspecting the fact, lost enough butter to pay for their farm. The appliances used in the Babcock test are now so cheap that every farmer 
can afford to have one. Neighbors having small dairies can get along very well with one instrument to two or three dairies. Where a man has ten or more cows it is better to have one of his own. Full directions come with each machine. Nothing needs to be said as to its operation. It is best to get some friend familiar with its use to come and operate it the first time. A test from a single milking is not sufficient. It should be made from a mixture of equal parts of not less than four milkings. In reading the test, the bottle should be held level with the eye, and the reading made accurately. This will be quickly learned. It should be read as soon as possible after the last whirling ceases. The fluid contracts as it cools and soon gets so that it cannot be read accurately.

When pouring in the acid, the bottle should be held in a slanting position, so that the acid will flow down the side of the bottle, which should be slowly turned as it is filled. This prevents too much of the acid coming in contact with a small portion of the milk and burning it. The bottle must be held firmly, so that it will not slip. The acid must be thoroughly mixed with the milk by rotating the bottle. When well mixed the liquid will have a bright, wine-colored appearance. The test must be made in a warm room, and some one should be present to take the record of the readings. From the results the number of pounds of butter fat the cow is producing daily can be readily computed. The butter production is calculated by adding one-sixth. If the result does not show what is expected or desired, the cow should be watched, and, if no im- 
provement be made, disposed of. Putting butter fat into milk is an individual power of the cow. A 3 per cent. producer cannot be made into one whose test shows 5 per cent. The quantity of her flow may be increased, but the quality of the milk is fixed by the cow herself. The Babcock test will not lie.

An unknown cow should never be bought without testing her with the Babcock test. If the owner of the cow has never used one he should be asked for a sample of the milk to test. Quantity of flow argues but little in the butter-producing dairy. Fifteen pounds of 6 per cent. milk is worth as much as thirty pounds of 3 per cent., and, as a rule, the former can be bought at a much smaller price than the latter. With the exception of the slight credit to be given for the skim milk, the production of the former, when it reaches the churn, is worth as much as that of the latter cow. It is better to have one three hundred pound cow than three one hundred and fifty pound cows. There are two extra cows to keep, and the big hole they make in the hay-mow and grain bin is not compensated by additional one hundred and fifty pounds of butter. The greatest profit ever made from the one hundred and fifty pound cow is when she is sold and the proceeds invested in a three hundred pound cow. All of this is demonstrated by the Babcock test.

The acid bottle should have a glass stopper. A graduate glass is needed in taking the acid from the large bottle. It should be used to pour the acid into the acid measure. It is better to have another pint bottle from which to pour into the graduate. 
Too much care cannot be exercised in handling the acid. For filling the test bottles, a pint cup with a spout at the bottom and rubber tube attached about eighteen inches in length should be used. By pinching the lower end of the tube when filling the bnttles the amount of water introduced can be controlled with great accuracy. The test bottles must be cleaned with warm water immediately after using. In pouring out the acid and milk, thorough shaking should be given to remove the sediment at the bottom of the bottle. The acid will cleanse and remove this better than water. Both the milk and the acid must be carefully measured. Negligence about this will yield unreliable results. 


\section{CHAPTER XXII}

\section{GENERAL HINTS}

\section{BUTTER PRINTS}

IN the matter of butter prints, one thing is important to retain customers. Every print must be full weight. An accurate and sensitive scale is essential. The butter print should be set so that the prints will be slightly over weight when made. They will lighten a trifle by evaporation. Allowance should be made for this. It is better to have the print half an ounce over weight than a quarter ounce short; a half ounce over weight will make the print safe. A good reputation is worth more than a fraction of an ounce.

Only good papers should be used for wrappers. It is a good idea to have the name of the dairy and the warranty printed on the wrapper. Where the market demands butter salted to different degrees the amount of salt can be indicated by some mark on the wrapper, or by a slip attached to it. By this the grocer will be able to exactly suit his customers, and those customers once secured will take the same brand of butter every time they can get it. It pays to build up a special demand market wherever possible. Once made, the dairyman is sure of it as long as the quality of the butter is maintained.

In summer it pays to use a wood or wood pulp case in which to put the prints. They cost but a 
trifle, and are an evidence of painstaking that in the end brings customers, and the dealer will appreciate these cases highly. Where delivery is made to spe-

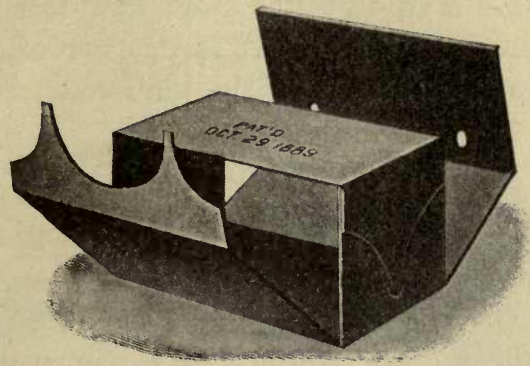

FIG. 3I-VENEER WRAPPER BOX, OPEN

cial customers, it is especially desirable to use these cases and in many places is good for an added cent a pound on the price. Maple is the best wood for the purpose. The covers are cheap when bought by

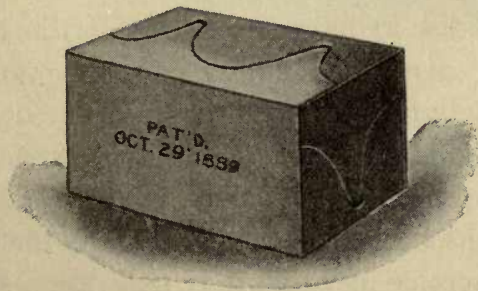

FIG. 32-VENEER WRAPPER BOX, CLOSED

the thousand and will always add to the selling price of the butter. A veneer wrapper open is seen in Fig. 31 ; closed in Fig. 32 ; the improved print carrier in Fig. 33, and the Eureka Butter Printer in Fig. 34. 


\section{MILK HABIT}

Occasionally cows will be found which show a disposition to be continuous milkers. As a rule it is better to have a cow go dry from four to six weeks, but if, after reasonable effort to dry her off, she declines to go dry, she should be humored. It is dan-

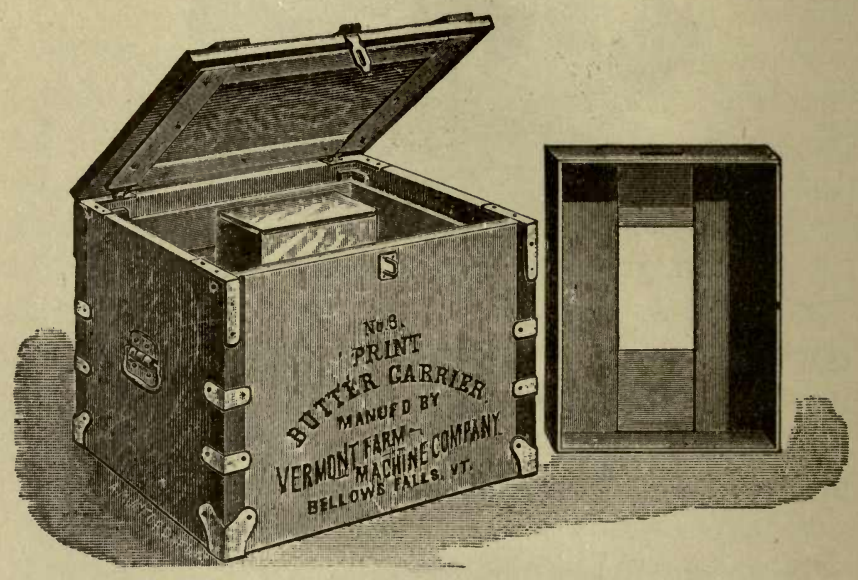

FIG. 33-IMPROVED PRINT EUTTER CARRIER

gerous not to do so. If in milk within three weeks of calving, no attempt should be made to dry her off. Heifers should be induced to continue their flow to within four weeks of calving if possible. If allowed to go dry too long, they form a habit hard to cure. An eye should always be kept open for well sired heifer calves from unusually fine milking cows. When there are not enough in a herd, the dairyman should look out for some in a neighbor's herd. The author knew one cross-bred Ayrshire-Durham cow that was 
a 400-pound butter producer, and which always had heifer calves. She did excellent work in stocking two herds with fine cows. Her daughters, granddaughters, etc., were strongly marked after her. A

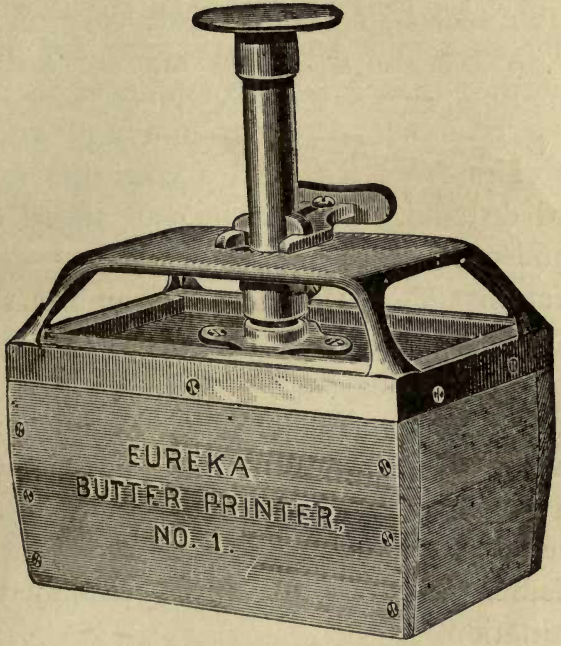

FIG. 34-IMPROVED BUTTER PRINTER

superior cow is a thing to be desired in the dairy, even though she cannot boast of registry. Quarts of milk and pounds of butter are very acceptable substitutes for a registry certificate.

\section{SELLING COWS}

No heifer or cow should be offered for sale for other than she is. If a registered herd be kept and the owner have doubts about the cow proving satisfactory to the purchaser for the purpose he desires her, no price should be fixed upon her and she should 
not be sold. If she be a fine looking cow, he may be tempted to take her and run the risk, but the seller cannot afford to allow a cow to go from his stock that does not fairly represent it. It is better to sell a cow for beef for less than she is worth than to sell her as a milk and butter cow for more than she is worth. It is a high compliment to a breeder to have a customer come to him and ask him to select for him from the herd a cow that is to fill a prescribed demand. No breeder can afford to betray such confidence.

A heifer that should go to the shambles should be killed at home so that the butcher cannot afterward take advantage of the reputation of the herd and sell her for milk prices. The reputation of the herd may suffer unless this be done. The breeder who sells from his herd as milk cows animals he has reason to believe will not do justice to his reputation as a breeder is selling that which money cannot buy back -his reputation.

\section{MILK PAILS}

Milk pails should be made to order, and all should be of the same weight, to make the weighing of milk convenient. One setting of the scales will then do for all the pails. Use nothing but strong, heavy tin for this purpose. Galvanized iron should not be used in any vessel intended as a receptacle for milk. It is rough and difficult, almost impossible to keep clean.

\section{THE SCRAP BOOK}

Every farmer, whether a stock raiser or not, should have a scrap box and a scrap book. Whenever in 
reading he finds an idea that is worth saving for future use, it should be cut out and put in the scrap box. When a quantity has accumulated they may be pasted in the scrap book. This book should be well bound. An old cloth-bound account book, with about two-thirds of the leaves cut out, is good for the purpose. A carefully prepared index by topics is indispensable. In this manner a large amount of valuable information can be soon accumulated. Experience is a valuable teacher, but an expensive one. But when experience can be procured by proxy, it is like getting an article as good as new and at a great reduction on first cost. A man may tell in half a column what has cost him years of experience to learn. The writer has in this way gathered three books full of the life experience of others. The value of such a book to its compiler is beyond estimate.

\section{RECORD OF COWS}

A book in which to enter the name, age, parentage and record of each cow is also indispensable; such data cannot be trusted to memory. A good plan is to have a marker in the ear of each animal with the rumber of the animal and the owner's name. In case of strays it is a matter of identification and enables the owner to keep a correct record of the animal. An excellent practice is to have the name and herd number of each cow placed over her stanchion. The names may be lettered with a stencil outfit costing about seventy-five cents. In the record book a sufficient space under the name of each cow is needed for any important remarks in relation to her production and history. 


\section{MEDICINE CHEST}

The writer has used a box in the barn or the house to keep a supply of standard remedies which he feels may be needed in case of emergency. The following is a partial list of the remedies he keeps on hand: Aconite, laudanum, Epsom salts, ginger, extract of pokeroot, iodide of potassium, white pine tar, sulphur, saltpetre, raw linseed oil, extract witch hazel, carbolic acid, spirits of turpentine, chloral, vaseline.

\section{CHOKING CATTLE}

Every cattle raiser should at all times have on hand a piece of stiff rubber hose about four feet long for use as a probang when cattle get chocked. Whenever any article of food sticks in a cow's throat, a piece of lard about the size of a hen's egg is introduced. The warmth of the throat will melt the lard and lubricate the throat and often enable the cow to get rid of her difficulty. If this fails, a clevice may be inserted, or something made for the purpose in the cow's mouth to keep her teeth apart. The hand and arm may then be greased and shoved down her throat to remove the obstacle. If this is unsuccessful, the probang may be put into the throat, and the obstacle pushed down to the stomach. This will usually be successful. A wilted turnip is one of the worst things to get into a cow's throat. The probang is about the only remedy. A broomstick or other stiff article if used for this purpose is likely to perforate the gullet and kill the cow. Soap and milk poured down the throat will sometimes give relief. More than a pint should never be used. 


\section{SKIM-MILK AS CALF FOOD}

The essential element of food for growing animals is protein. From it are gathered the materials that make bone, nerve, muscle, blood. The food must, however, contain sufficient carbohydrates to furnish warmth and motive power. Skim-milk contains nearly all the protein there is in new milk. A comparison of the fresh with skim-milk shows what is taken out by skimming:

Protein Carbohydrates

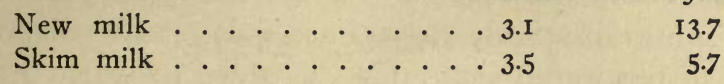

New milk is a nearly balanced ration for the calf; skim milk is too narrow for a full ration. The loss of fat must be made up with some other food. As the animal is growing, added protein is also important. The most direct method of supplying carbohydrates is to feed fine ground meal. It is better for the young calf if cooked before feeding, and then thoroughly stirred with the milk. After the calf is a couple of weeks old it can assimilate fine ground meal if fed in small quantity. Oil-cake meal soaked for about twelve hours in five times the quantity of water readily mixes with the skim-milk and furnishes cxcellent nourishing feed. 


\section{CHAPTER XXIII.}

\section{DAIRY REMEDIES}

For Scours in calves is recommended equal parts of extract of tannin and laudanum. Other suggested remedies are: one dram deodorized tincture of opium in starch three times a day; one teaspoonful of powdered asafœetida dissolved in warm water or whiskey, or fed in the powdered state in scorched milk; a tablespoonful pulverized charcoal and molasses three times a day.

For Malignant Fouls the writer recommends cleaning the foot thoroughly and applying Arabian horse liniment; it has cured every case in his herd. $\mathrm{He}$ also recomends one pound white pine tar, put in a can with two ounces gunpowder, two ounces white vitriol, two ounces saltpetre, powdered fine, and a little carbolic acid. Cleanse the foot thoroughly and apply the preparation. Repeat daily until cured. Cleansing daily is important with all remedies.

For Garget physic with one pound Epsom salts dissolved in one quart of warm water, with two ounces ginger. Follow this with one teaspoonful of phytolacca (extract pokeroot) twice a day. Bathe the udder with a solution of one tablespoonful of phytolacca in one pint extract witch hazel, rubbing it until dry. Keep the cow on dry liberal bed- 
ding. In a bad case give ten drops of aconite, night and morning.

For Bloody Milk use the above remedy. Give powdered sulphur and alum, one teaspoonful daily.

For Diarrhea and Prolapsus use the above remedies, also an injection of extract tannin, starch and laudanum.

For Caked Udder, rub the udder thoroughly for ten or fifteen minutes three times daily, with water as hot as the hand can bear. Rub dry and then apply warm raw linseed oil freely with the hand. The udder will absorb a considerable quantity, often half a pint.

Physic for Cows.-From one to one and one-half pounds Epsom salts, with two ounces ginger, according to size and condition of cow, dissolved in one quart of water, is recommended for one dose.

Prolapsus Uteri (Inversion of Womb).-Carefully place a clean sheet under the parts inverted, if the cow is down, then wash and carefully cleanse with sponge or cloth and warm water. Push back to place with folded hand. Never distend the fingers in the operation, as there would be danger of puncture. If the cow is in distress and strains so as to prevent crowding the parts back, give one ounce chloral. As soon as straining stops, crowd the inverted parts to place and hold them there with pine plug made smooth, with knob at end. The plug should be about twelve inches long and two inches thick, with cloth placed over the end. The plug is held in place by means of a heavy duck bandage. One or two of these bandages should always be on hand, for when wanted there is no time to make 
one. The upper pieces pass over the back and the others between the legs and are fastened to a horse collar about the neck, or a strap about the breast. When the cow recovers from the effect of the chloral, which is likely to cause her to sleep, give from one and one-half to three ounces of laudanum according to the size of the cow and the apparent degree of pain. Take out the plug once or twice a day and cleanse, putting on new rag. This should be oiled or greased with tallow, sweet oil or vaseline. Tie the cow so that as she stands her hind jeet will be the highest. Keep the bandage on for several days -as long as there is any evidence of straining. In giving chloral, mix it with a pint of water. Repeat the dose in half an hour if necessary to stop the straining.

Milk Fever is one of the most serious diseases of well-bred cattle. None but good cows have it. It seems to be most prevalent among grass fed cows. The danger is greatest during June, July, August and early September. The cow should be put in the barn and confined to dry hay feed for a week or more prior to coming fresh. A dose of salts and ginger is often given three or four days before calving, and another immediately after-that is, within five or six hours. A pail of warm water two or three times a day is given for several days. For several days the cow should not be allowed to drink what cold water she wants.

The "Schmidt Cure."-In former days veterinary surgeons lost 85 per cent. of their cases. Recently the Schmidt cure has been used with great success. Many report as high as 85 per cent. cures; 
some 90 per cent. Soon after the disease is developed the throat becomes paralyzed and the cow cannot swallow. If then fed at the mouth, she is likely to choke to death. The pint cup used in the Babcock test and about three feet of rubber tube, about the size used with nursing bottles, are used. A silver or rubber milking tube is inserted in the free end. In absence of this a good quill will do. After disinfection with hot water and cleansing the hands, udder and teats with hot water, I20 grains (two drams) iodide potassium, are dissolved in one quart of water that has been previously boiled and allowed to cool to Ioo degrees. The milk tube is then introduced in each of the teats and one-half pint of potassium solution is injected by holding the cup as high above the udder as the length of the tube will allow. The udder should be milked dry before the operation, after which it should be rubbed from the teat toward the body.

Just prior to the publishing of this book, a novel remedy for milk fever was announced and has received recognition from the agricultural department of the United States, in circular No. 45 of the Bureau of Animal Industry, issued by Dr. D. E. Salmon. Many remarkable cures are credited to its use. The treatment is as follows: After cleansing the hands and the udder, and disinfecting the implements, a clean towel is placed under the udder, previously emptied of milk. An ordinary bicycle pump with silver or rubber tube to be inserted in the teat is used to fill each quarter of the udder with air, and a rubber band or soft cloth string applied to each teat to retain the air. By gentle massage 
the air is worked through the udder. The tapes should be removed three or four hours after the cow gets on her feet. The operation may be repeated. When recovery is assured the air should be worked out by the process used in milking.

The progress of milk fever is rapid. If not arrested, the animal usually dies in from ten to twenty-four hours. The symptoms looked for are: first, a vacant stare of the eyes, accompanied with slight twitching of the muscles. The cow usually refuses food and drink. She ceases to ruminate. These symptoms are followed by evilences of acute pain in the body, weakness and staggering and often actions suggestive of insanity. The hind quarters become stiff and inactive and the animal goes down. She may get up two or three times, but is soon unable to get to her feet. She bends her neck toward the side. This is a characteristic symptom. If she be disturbed she will resume her former position. When she goes down remedies at the mouth are useless. She cannot swallow. Her eyes become glassy and fixed. This is followed by continued depression. Unless relief is speedily had, death follows in a few hours.

The foregoing remedy is the nearest a specific for this disease that has yet been discovered. After the cow is attacked there is little time to seek the druggist for the remedies. All this should be ready beforehand. The fæces, which will be hard, should be removed by the hand and this be followed by a copious injection of castile soap suds. In the absence of that, soft soap suds will do. A handful or so of salt may be added to the gallon of soap and 
water. Warm bran mash may be given when the cow can eat. Plenty of dry straw bedding is needed. One part carbolic acid to one hundred of water makes a good disinfectant to use on the hands and the udder of the cow before injecting the remedy.

Blackleg.-The mortality of this disease is very high. The only remedy the writer has ever used with anything like success is bleeding freely in the neck as soon as the animal is found to have the disease. If the blood can be started and caused to flow freely, recovery will usually follow. Prevention by inoculation should be always resorted to as soon as the disease breaks out in the herd, and the afflicted animals removed at once from the herd. The material for inoculation can be obtained from the state veterinarian on application.

Stringy Milk.-In reply to an inquiry addressed to the Pennsylvania State Veterinarian, Dr. Leonard Pearson, of the department of agriculture, he says:

"This abnormality is due to a fermentation caused by bacteria, which enter the milk and produce a change in the milk sugar, causing it to become viscous. The infection of the milk with the particular organism which causes this change occurs after the milk leaves the cow. It is probable that the stable dust is infected with this germ, and of course it also exists in the milk house and upon the milking, utensils. The way to get rid of it is thoroughly to disinfect the stables by spraying with a 5 per cent. solution of carbolic acid and then wash off the surface of each cow by a 2 per cent. solution of creolin. This is somewhat risky in cold weather, and 
should be deferred until the conditions are more favorable. The milk house or milk room should be thoroughly disinfected, and for this purpose it is well to use formaldehide. The utensils, in fact, everything that comes in contact with the milk, should be sterilized by boiling or steaming them in a closed chest or closet under low pressure. It may be well to repeat the course of disinfection two or even three times. If it be persisted in there can be no doubt that it will result in eradicating the difficulty."

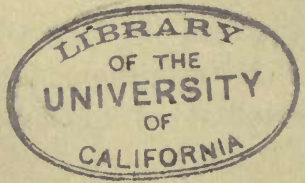


Carbo- Manurial value

Protein hydrates perton

Corn silage at glazing r.I

18.2

Alfalfa hay ... 10.4

Corn Stover, cured . . 2.0

Clover hay .... 6.4

Millet hay .... 4.5

Oat straw ..... 1.4

Orchard grass . . . 4.8

Rye straw . . . . . . 0.6

Timothy hay .. . 2.9

Wheat straw. .0 .6$

Buckwheat straw $\quad$. $\quad 5.2$

43.0

34.8

38.5

54.7

45.9

45.2

43.5

46.9

39.3

35.1

ROOTS

Carrots . . . . . . . 0.9

Mangel wurzels ... I.I

Potatoes . . . . . 0.9

Rutabagas . . . . . I.I

Turnips ..... I. 1.0

8.9

5.4

15.7

8.5

7.7

$\$ 1.13$

7.34

4.13

7.47

4.46

2.89

5.35

2.12

4.35

2.02

GRAIN

Corn ...... 6.3

Barley ..... 8.7

Oats . . . 9.2

Peas . . . . . 18.8

74.9

69.2

53.2

Rye ...... 6.4

53.5

70.3

.94

.91

.85

I.04

.90

MILL PRODUCTS

Buckwheat Mids. . 23.7

Corn meal ..... 5.5

Corn and cob meal . . 4.4

Pea meal . . . . 16.8

Wheat bran . . I 12.0

Wheat Mids. . . . . 12.8

Wheat shorts . . 12.2

$50.5 \quad 14.03$

$71.1 \quad 4.70$

$66.5 \quad 4.31$

53.I 9.04

$45.4 \quad 10.33$

$60.9 \quad 7.70$

$\begin{array}{ll}58.6 & 7.56\end{array}$

BY-PRODUCTS AND WASTE MATERIAL

Brewers' grain, dried 16.8

Gluten feed .... $\quad 19.4$

Chicago gluten meal . 27.7

Hominy chops ... 7.I

Linseed meal, N.P. . 28.9

47.1

63.3

56.9

79.5

Linseed meal, O.P. - 29.3

44.9

48.5

Malt sprouts

18.6

40.3

9.88

8.63

I 3.53

I6.73

15.73

II.29

DAIRY PRODUCTS

Buttermilk . . . . 2.8

Milk ....... 3.I

5.0

13.7

Skim milk .... 3.5

Whey ..... 0.8 


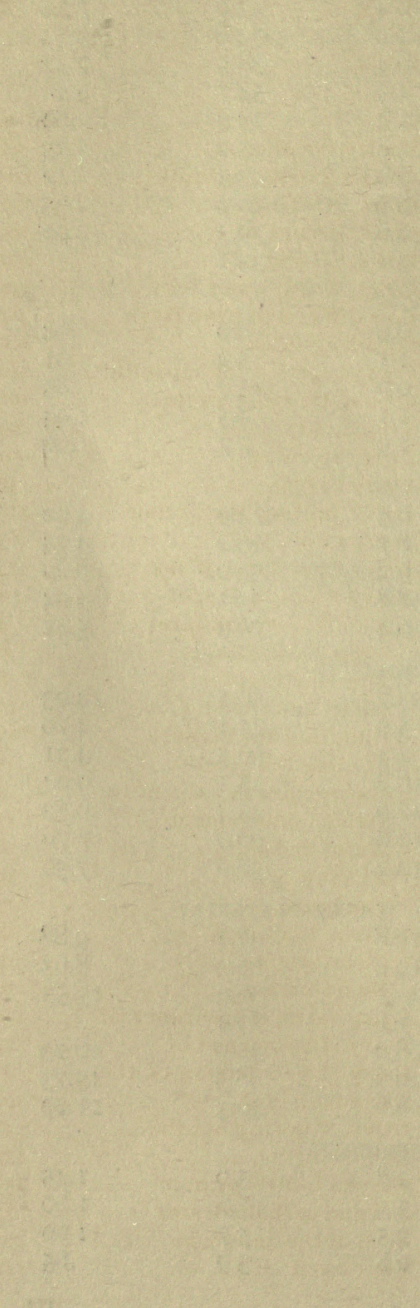




\section{N D E X}

PAGE

PAGE

Advance in methods. . . . . 136

Agitator, Cream ....... Iro

A nalyses of feeding stuffs . . . I I I

Appearances of dairy farm . . . 120

A ppliances ......... 143

Babcock Test ........ 150

Balancing a ration ...... 76

Barn The dairy ........ 122

Floor ............ 123

Stanchions........ I25

Ventilation........ 126

Feed room .......... 128

Hospital stalls ....... 128

Milk room ......... 129

Brand for the product ..... II9

Breed, selection of a . . . . 56

Breeding. Advantages of Special 57

Breeding, Cross ........ 60

Breeds Dairy........ 3I

Jersey.......... 3I

Guernsey........ 37

Ayrshire ....... 4 I

Holstein Friesian ..... 46

Shorthorn or Durham . . . 50

Butter Carrier, Print . . . . . I58

Butter printer ........ I59

Butter prints ........ $\mathrm{I}_{56}$

Butter workers. . . . . . 143

Butter working and salting . . . I15

Calf feed, skim-milk as .... I63

Carbohydrates ........ 77

Carding and brushing.... 8 $8 \mathrm{I}$

Care of milk ........ 93

Care of the cow ...... 80

Cattle choking ........ 162

Centrifugal process ..... 94

Chokıng cattle........ 162

Churning. ......... I12

Churning point ...... 103

Churns.......... $\mathrm{II}_{3}$

Clover and alfalfa ...... 90

Cooley creamer . . . . . . . . . 91

Cost of producing milk . . . 140

Cows, Kicking ....... I 139

Cows, Record of ....... I6I

Cows, Selling. ...... 159

Cows, Warm water for . . . I40

Cows, when to have fresh . . . 87

Cream agitator . . . . . . IIO

Cream. Device for ripening. . I I

Cream, Keeping sweet . . . . . Ior

Cream, Ripening of ..... 99

Cross breeding....... 60

Dairy Breeds . . . . . . . . 3I

Dairy Butter, Marketing . . . II8

Dairy Cow ......... 63

Dairy Cow, Feed of the .... 73

Dairy Farm, A Model ..... I

A walk over the farm .... 4

Soiling and silage ...... 6

The Hay crop ....... 8

Silage and the silo...... I0

Handling the manure ..... II

Feeding the stock ...... I2

Management of the milk . . . I4

Stable management ..... I5

Water and salt ....... I6

Milking .......... I6

The Barn .......... I7

Farm buildings ....... 18

Disinfectants........ 19

No failures ......... I9

Dairy farm, Appearance of . . 120

Dairy, Importance of . . . . 2 2 I

Dairy Sire, Selection of the . . 66

Dairy Standard. . . . . . 69

Dairy, weeding out the .... 136

Dehorning ......... 137

Eureka butter printer . . . . 159

Fat and carbohydrates . . . 77

Feed of the dairy cow . . . . 73

Feed room .......... 128 
PAGE

Feeding Stuffs, Analyses of . . . 17 I

Feeding the dairy cow ..... 138

Feeds and their value ..... 99

General hints ........ ${ }_{156}$

Gravity process ..... 93, 97

Heifer, The ........ 7 I

Hospital stalls ........ I26

Ice houses .......... I47

Importance of the dairy .....2 2 I

Keeping cream sweet ...... Ior

Kicking cows ....... 139

Ladles ........... I45

Manurial value of feeding stuffs. 9 I

Marketing dairy butter ..... II 8

Medicine chest ........ I62

Methods, Advance in . . . . ${ }_{136}$

Milk, Care of ......... 93

Milk, Composition of ..... 25

Milk, Cost of producing . . . . 140

Milk habit ......... $15^{8}$

Milk pails .......... 160

Milk, Physiology and secretion of 22

Milk room ........ 129

Milk, skim .......... 142

Milking ......... 83

Milking, Bad habits to avoid in . 83

Milking stools . . . . . . . 149

Milking, Waste in ....... 138

Miscellaneous topics . . . . . I 136

Model dairy farm, A ...... I

Name for the farm ....... II9

Oats and peas ........ 9r

Paddles............ I45

Physiology and secretion of milk 23

Print butter ......... 12I

Print butter carrier . . . . . $15^{8}$

Protein......... 76

Record of cows........ I6 $16 \mathrm{r}$

Remedies, Dairy ....... 164

Remedies, Malignant fouls . . 164

Garget .......... . 164

Bloody milk ........ 165

Diarrhøea and prolapsus . . . . I65

Caked udder........ 165

Physics for cows . . . . . 165

Prolapsus uteri....... . 165

Milk fever ........ 166

Schmidt cure....... 166

Black leg . . . . . . . . 169

Stringy milk ........ I69

Ripening cream, Device for . . . 104

Ripening of cream . . . . . . 99

Salt.......... 74

Scrap book ........ 160

Selection of a breed ..... $5^{6}$

Selling cows ........ I59

Silage.......... 75

Silo and silage . . . . . . 132

skim-milk .......... $\mathrm{I}_{42}$

Skim-milk as calf food .... I63

Special breeding, Advantages of . 57

Stable, Temperature of . . . . 82

Stalls, Hospital ........ 126

Stanchions......... 125

Starter.......... IOI

Temperature of stable..... 82

Thermometers........ 145

Tools, Care of ....... I47

Value of feeds ........ go

Veneer wrapper boxes..... I57

Ventilation ......... I26

Warm water for cows ..... I40

Waste in milking ...... 138

Water and salt . . . . . . 74

Weeding out the dairy . . . . . . ${ }^{136}$

When to have cows come fresh .87

Working and salting butter. . . II5

Scours ......... I64

Wrapper boxes......... I57

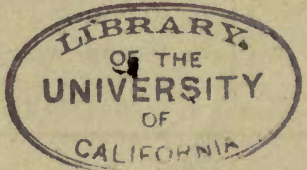




\section{The Improved}

\section{U. S. Cream Separator}

WON

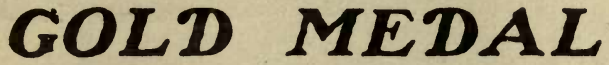

The Highest Award

at the Lewis and Clark Exposition. Portland. Oregon r 905. At the Pan-American Exposition in Igor, the U.S. Separator, besides winning Gold Medal (Highest Award), established the

\section{World's Record}

For Clean Skimming

averaging in 50 consecutive runs to leave 25 per cent less

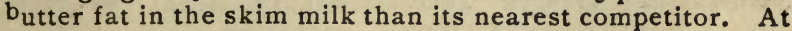
the Lewis and Clark Exposition the U. S. still further lowered this record in a three days composite test of the separated milk from all the cows of all the dairy herds at the Exposition. This last was even a harder test than the famous Pan-American run.

As there was no skimming contest at the St. Louis Exposition last year the U.S. Separator continues to maintain indisputable right to the title of the best and most efficient machine of its kind.

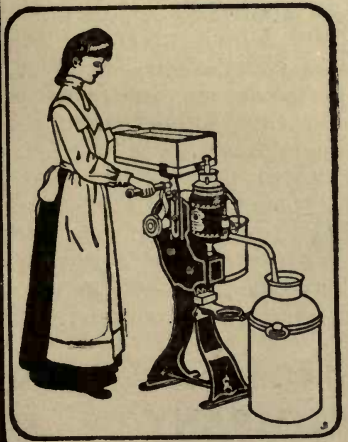

Our catalogues explain more in detail why this is true. A copy is free for the asking. Address,

VERMONT FARM MACHINE CO. Bellows Falls, Vermont

Eighteen centrally located distributing warehouses throughout the United States and Canada. 


\section{B L I Z Z A R D}

FEED AND ENSILAGE CUTTER AND SHREDDER

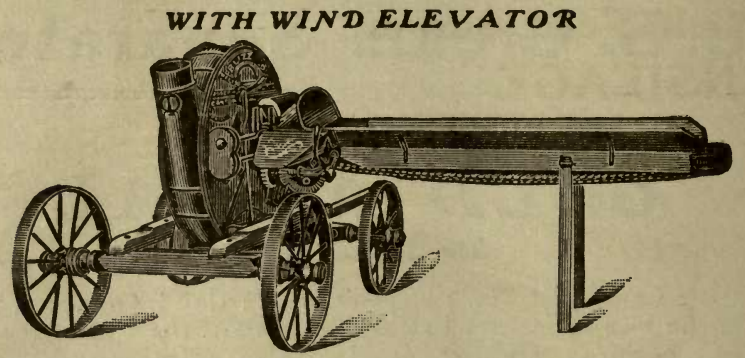

Does better work than any other Ensilage or Fodder Cutter ever made; will elevate to any desired height, and in any direction, green or dry material into silo or any other place desired.

Does perfect work in shredding and cutting dry stalks. Fully guaranteed. The cut shows New and Improved Cutter, with Self-Feed Table, mounted; can also be had unmounted.

\section{SEND FOR CATALOGUE \\ JOSEPH DICK AGRICULTURAL WORKS CANTON, OHIO. Dept. P.}

\section{AND HOW TO GROW THEM}

\section{By THOMAS SHAW}

This is the first book published which treats on the growth, cultivation and treatment of clovers as applicable to all parts of the United States and Canada, and which takes up the entire subject in a systematic way and consecutive sequence. The importance of clover in the economy of the farm is so great that an exhaustive work on this subject will, no doubt, be welcomed by students in agriculture as well as by all who are interested in the tilling of the soil. After thoroughly explaining the principles and practice of successful clover cultivation in general, the most important species and varieties are discussed in detail. With each are given its varieties, pasturing, harvesting for hay, saving seed, renewing, value as fertilizer. Thus each chapter is complete in itself.

Illustrated. $5 \times 7$ inches. 337 pages. Cloth, net, . $\$ 1.00$

\section{ORANGE JUDD COMPANY}




\section{Pe \\ 'OHIO"}

Self Feed Blower ENSILAGE

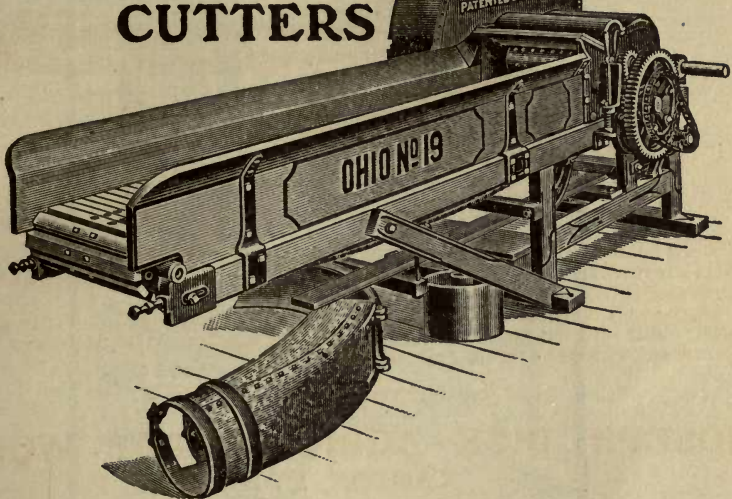

will cut more corn into half-inch lengths and elevate it into the Silo with a given amount of power than any Ensilage Cutters made. This has been demonstrated so often that it is now admitted that the "Ohio's" excel in the essentials of maximum capacity with the minimum of power. In proof note this table:

No. 14. Capacity 12 to 15 tons per hour cut in half-inch lengths.

Power 8 to 10 H. P. steam.

No. 17. Capacity 16 to 20 tons per hour cut in half-inch lengths.

Power 10 to 12 H. P. steam.

No. 19. Capacity 20 to 25 tons per hour cut in half-inch lengths. Power 12 H. P. steam.

Our own tests in actual operation show the above facts. The experience of thousands of owners of "Ohio" outfits show these same facts. To make every buyer absolutely safe we back these facts with a positive and reliable guarantee. In addition to the sizes named above we continue to make Nos. 13, 16 and 18 "Ohio" Self Feed Cutters, equipped with either Blower or Chain Elevators, as the buyer maydesire. The Self Feed on the "Ohio" increases the capacity $33^{1 / 3}$ per cent. and saves $662 / 3$ per cent. of the labor required in feeding a cutter. Our patented "Ohio" Silage Distributor, which is the latest and most efficient dist ributor made, saves the expense of one or more men in the Silo when cutting. Easily adjusted from the ground so as to distribute the cut material to all parts of the silo.

Our Large Illustrated Catalogue will give you a splendid idea of the "Ohio" Cutters, their quality and advantage. We will mail you a copy free if you will ask for it. Write to-day. "Modern Silage Methods," the latest and hest book on the subject, fully illustrated and covering the entire subject-construction, planting, feeding, results, etc., will be mailed for roc. coin or stamps. The "Ohio's" are manufactured only by

\section{The SILVER MANUFACTURING CO. SALEM, OHIO.}




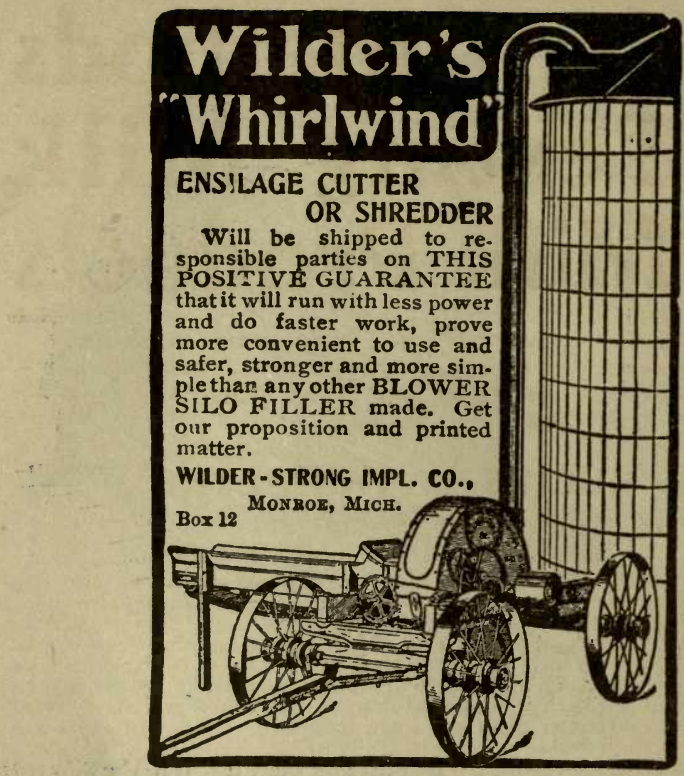

\section{DISEASES OF SWINE}

By Dr. R. A. CRAIG

\section{Professor of Veterinary Medicine at the Purdue University}

A concise, practical and popular guide to the prevention and treatment of the diseases of swine. In discussing the different diseases, the causes and preventative measures are given special attention by the author. The book is conveniently divided into four parts. Part I treats on general diseases, their diagnosis and the methods of administering medicines. With the discussions on each disease are given its causes, symptoms, treatment, and means of prevention. The succeeding parts treat on Surgical Diseases, Infectious Diseases and Parasitic Diseases. All technical and strictly scientific terms are avoided, so far as feasible, thus making the work at once available to the practical stock raiser as well as to the teacher and students.

Illustrated. $5 \times 7$ inches. 190 pages. Cloth . . . \$0.75

\section{ORANGE JUDD COMPANY}




\section{Modern Methods of Testing Milk and Milk Products}

$A$ Handbook Prepared for the Use of Dairy Students, Butter-makers, Cheese-makers, Producers of Milk, Operators of Condenseries, Managers of Milk Shipping Stations, Milk Inspectors, Physicians, etc. $\quad \because \quad \therefore \quad \therefore$

\section{By LUCIUS L. VAN SLYKE}

Chemist of the New York Agricultural Experiment Station

This book should be in the hands of every dairyman, teacher, and student. It contains a comprehensive discussion of the chemistry of cow's milk, embodying the most recently developed facts. The numerical data given are fresh and largely at first hand, representing American conditions, instead of being stale, miscellaneous data taken from European sources, so much of which has little application or value for American dairymen. Some errors that have been long incorporated in dairy literature on the composition of milk are here corrected. The publishers are a ware that the author's long-continued study of the chemistry of milk has made him a recognized authority in this field, and has peculiarly fitted him to treat this subject in a satisfactory manner.

The various methods of testing milk and its products are brought up to date; they are presented in the most concise manner that is consistent with completeness, clearness, and accuracy ; irrelevant matter is omitted. The aim has been to include all necessary material and omit all that is unnecessary.

After the description of the details of each method, there follows a brief summary in short, sharp statements that stick in the mind and enable the student to grasp almost at a glance the essential steps to be followed, and the important precautions to be observed.

Considerable new matter is presented. The portion on "Methods of Testing and Scoring Butter, Cheese, Milk, etc.," is a feature that will" commend itself to dairy teachers, students, and inspectors. Several valuable tests, easy of execution, are given for the detection of renovated butter, of oleomargarine, and of other adulterants of dairy products, Methods are given for the determination of fat in the milk powders which are recently coming into the market, and which are destined to be of great commercial importance to dairymen.

The chapter on the "Arithmetic of Milk and Milk Products" is another desirable feature of the buok which will prove exceedingly helpful to every dairy teacher, student, and worker. We believe that the general arrangement of the material in this book is one that will meet the approval of those who have occasion to use it most.

Fully Illustrated, $5 \times 7$ inches. Substantially bound in cloth. Price, 75 cents

\section{ORANGE JUDD CO.}

439-441 Lafayette Street, - - New York 
A Compendium of Agricultural Science and Practice on Farm, Orchard and Garden Crops, and the Feeding and Diseases of Farm Animals : : :

\section{By EARLEY VERNON WILCOX, Ph.D} and CLARENCE BEAMAN SMITH, M.S Associate Editors in the Office of Experiment Stations, United States Department of Agriculture

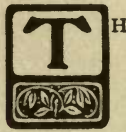

HIS is a new, practical, and complete presentation of the whole subject of agriculture in its broadest sense. It is designed for the use of agriculturists who desire up-to-date, reliable information on ail matters pertaining to crops and stock, but more particularly for the actual farmer. The volume contains

\section{Detailed directions for the culture of every}

\section{important field, orchard, and garden crop}

grown in America, together with descriptions of their chief insect pests and fungous diseases, and remedies for their control. It contains an account of modern methods in feeding and handling all farm stock, including poultry. The diseases which affect different farm animals and poultry are described, and the most recent remedies suggested for controlling them.

Every bit of this vast mass of new and useful information is authoritative, practical, and easily found, and no effort has been spared to include all desirable details. There are between 6,000 and 7,000 topics covered in these references, and it contains 700 royal $8 \mathrm{vo}$ pages and zearly 500 suberb half-tone and other original illustrations, making the most perfect Cyclopedia of Agriculture ever attempted.

Handsomely bound in cloth. $\$ 3.50$ : half morocco (very sumptuous), \$4.50, postpaid

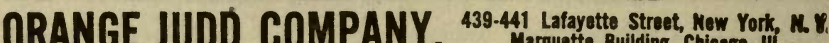

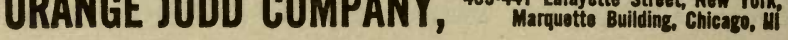





\section{University of California Library or to the}

NORTHERN REGIONAL LIBRARY FACILITY Bldg. 400, Richmond Field Station University of California Richmond, CA 94804-4698

ALL BOOKS MAY BE RECALLED AFTER 7 DAYS

2-month loans may be renewed by calling (510) 642-6753

1-year loans may be recharged by bringing books to NRLF

Renewals and recharges may be made 4 days prior to due date

DUE AS STAMPED BELOW

\section{JUN 141994}




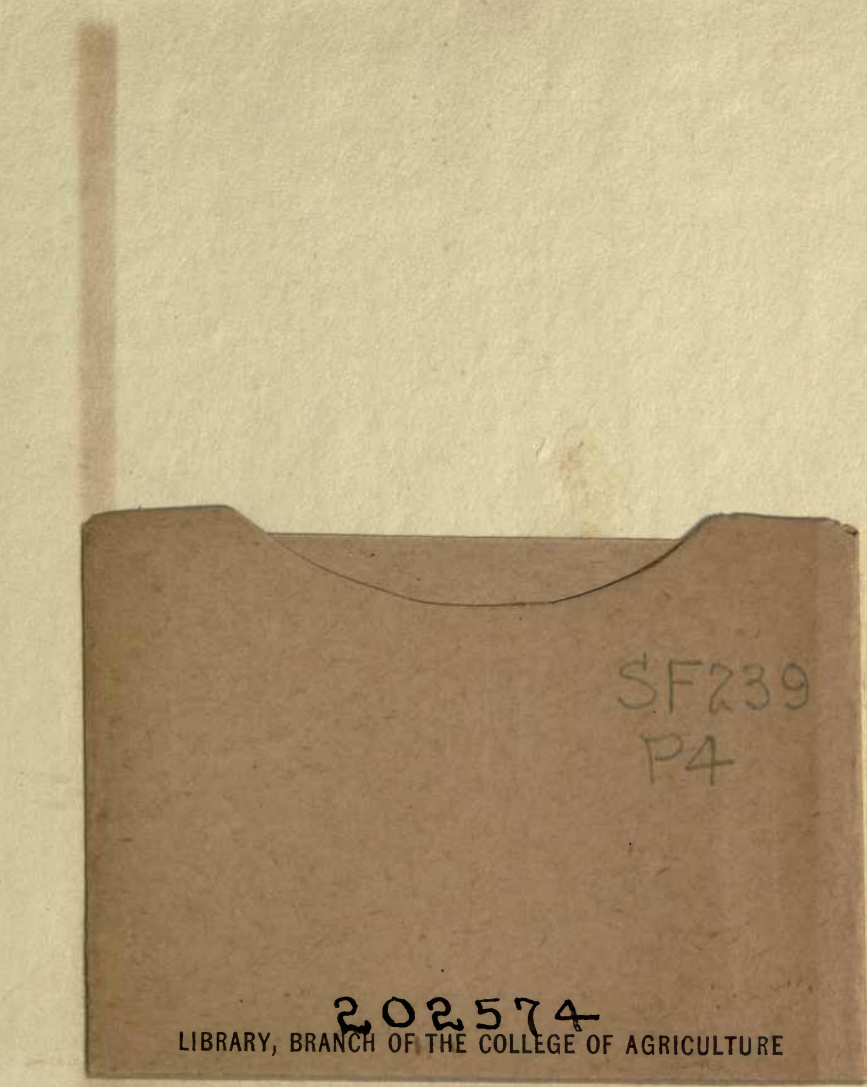




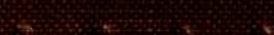

$\frac{5}{450}$ 